\title{
Phosphorus recovery from municipal sludge-derived ash and hydrochar through wet-chemical technology: A review towards sustainable waste management
}

\author{
Huan Liu ${ }^{\mathrm{a}}$, Guangji Hu ${ }^{\mathrm{b}}$, Ibrahim Alper Basar ${ }^{\mathrm{a}}$, Jianbing Li ${ }^{\mathrm{c}, \mathrm{d}}$, Nathalie Lyczko ${ }^{\mathrm{e}}$, Ange Nzihou ${ }^{\mathrm{e}}$, \\ Cigdem Eskicioglu ${ }^{\text {a,* }}$ \\ ${ }^{a}$ UBC Bioreactor Technology Group, School of Engineering, The University of British Columbia, Okanagan Campus, 1137 Alumni Avenue, Kelowna, BC V1V 1V7, \\ Canada \\ ${ }^{\mathrm{b}}$ School of Engineering, The University of British Columbia, Okanagan Campus, 1137 Alumni Avenue, Kelowna, BC V1V 1V7, Canada \\ ${ }^{\mathrm{c}}$ Environmental Engineering Program, University of Northern British Columbia (UNBC), 3333 University Way, Prince George, BC V2N $4 Z 9$ Canada \\ ${ }^{\mathrm{d}}$ WZU-UNBC Joint Research Institute of Ecology and Environment, Wenzhou University (WZU), Wenzhou, Zhejiang Province 325035, China \\ ${ }^{\mathrm{e}}$ Université de Toulouse, IMT Mines Albi, RAPSODEE CNRS UMR-5302, Campus Jarlard, Albi 81013 Cedex 09, France
}

Keywords:

Resources recovery

Thermochemical treatment

Phosphorus extraction

Crystallization

Waste valorization

Fertilizer

\begin{abstract}
A B S T R A C T
Phosphorus (P) is a non-renewable resource, and its recovery and recycling are necessary for meeting future $\mathrm{P}$ demands and environmental conservation. Ash and hydrochar from incineration and hydrothermal liquefaction (HTL) of municipal sludge, respectively, represent promising sources for efficient P recovery. The full-scale application of wet-chemical techniques has proven their technical feasibility for $\mathrm{P}$ recovery from sludgederived ash. HTL for sludge treatment has received significant attention for producing biocrude with netpositive energy recovery. P recovery from the solid by-product of sludge HTL, hydrochar, is a critical step in holistic sustainable sludge management. This review aims to guide $\mathrm{P}$ recovery from sludge-derived ash and hydrochar by presenting recent advances in wet-chemical extraction and precipitation. By comparing their characteristics, ash and hydrochar derived from municipal sludge exhibit similar feasibilities and challenges for $\mathrm{P}$ recovery. Extraction is recognized as the critical step for $\mathrm{P}$ recovery. The advantages and disadvantages of various $\mathrm{P}$ extraction approaches are provided. Acidic extraction achieves high efficiency (up to 100\%) but requires removal of co-extracted heavy metals. Alkaline extraction prevents metals contamination but shows low efficiency $(<70 \%)$. Sequential extraction is first identified as an important advance in this review, with promising $\mathrm{P}$ extraction efficiencies (70-91\%) and low metal interferences. Three possible fertilizers (struvite, calcium phosphates, and vivianite) are recommended through the final precipitation, given their pros and cons of recovery. Ultimately, this review highlights the need for a wastewater biorefinery integrating wastewater treatment, HTL (energy recovery), and nutrient recovery for sustainable sludge management.
\end{abstract}

Abbreviations: ACP, amorphous calcium phosphate; Al-P, aluminum phosphate; AP, apatite phosphate; Ca-P, calcium phosphates; CER, cation exchange resin;

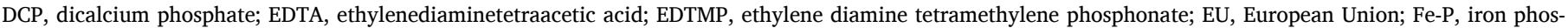

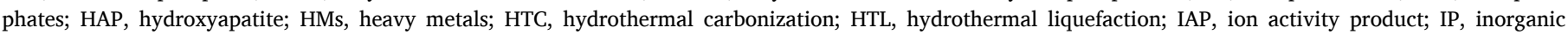

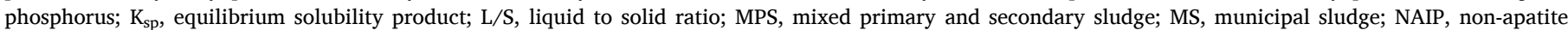

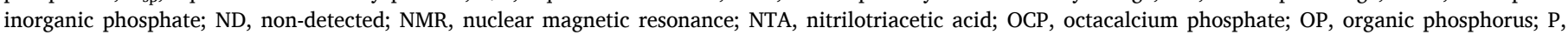

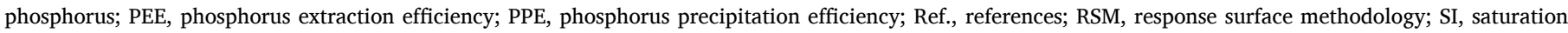

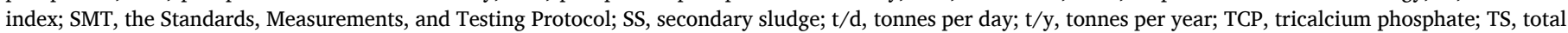
solids; XANES, X-ray absorption near edge structure; XRD, X-ray diffraction.

* Corresponding author.

E-mail addresses: liu@alumni.ubc.ca (H. Liu), guangji.hu@ubc.ca (G. Hu), alperbasar@alumni.ubc.ca (I.A. Basar), jianbing.li@unbc.ca (J. Li), lyczko@mines-albi. fr (N. Lyczko), ange.nzihou@mines-albi.fr (A. Nzihou), cigdem.eskicioglu@ubc.ca (C. Eskicioglu). 


\section{Introduction}

Phosphorus (P) is a fundamental nutrient that sustains all life on earth. It forms the basis of living organisms, such as phosphodiester bridges in nucleotide chains, adenosine triphosphate for energy transfer, phospholipids in cellular membranes and proteins, and calcium phosphates (Ca-P) in teeth and bones [1]. Thus, $\mathrm{P}$ deficiencies would highly inhibit cell growth and other functions (e.g., crop yields). Plants take up $\mathrm{P}$ from soil while animals acquire it from plants or animals at lower trophic levels [2]. However, a recent global meta-analysis suggested that nearly half of aboveground plant production suffered from a significant $\mathrm{P}$ limitation in natural terrestrial ecosystems [3]. Due to the limited amount of bioavailable P (i.e., orthophosphate) in natural soil, P is primarily extracted from mined phosphate rock (containing $11-15 \%$ of P) and $80-90 \%$ is used as fertilizer [4].

The global amount of phosphate rock exploration has quadrupled during the last 80 years due to the increasing agricultural demand for $\mathrm{P}$ fertilizers [5]. Phosphate rock is non-renewable as it takes tens of millions of years to form the principal resources (sedimentary marine phosphorites and igneous deposits) through natural $\mathrm{P}$ cycle [6]. Phosphate rock is also highly unevenly distributed across the globe despite the abundant reserve (approximately 69 billion tonnes according to current data) [7]. As shown in Fig. 1a, over 70\% of phosphate rock is located in Morocco and Western Sahara, which have $<1 \%$ of the world population. However, with the world's largest population, China only shares $4.6 \%$ of phosphate reserve, while India nearly has no domestic resources [4]. Based on the current data of phosphate rock reserves in Canada, China, Russia, and the United States (US) (25, 3,200, 600, and 1,000 million tonnes, respectively) and their mine production rates $(0.8$, 110,14 , and 23 million tonnes/year, respectively), phosphate reserves in those geometrically large countries could be exhausted within a short period (29-43 years) [7,8]. Many countries with limited geological $\mathrm{P}$ sources must rely on imports either partially or entirely, which causes political and economic risks. The imbalanced distribution of $P$ resources and uncertainty of markets have triggered global food insecurity with a 14-month price spike (700\% upward) in 2008 [6]. During that period, $>40$ countries suffered from food prices sparked riots, which was at least partially caused by jumping fertilizer prices [5]. Unlike fossil fuels, P cannot be replaced or synthesized when it is scarce or expensive. On the other hand, the lost $\mathrm{P}$ ends up as the primary contributor to aquatic eutrophication, posing severe threats to ecosystem and water supplies [9]. Collectively, P recovery and recycling strategy has been recognized as a necessary approach to meet future P demands, sustain food production, and preserve the environment.

Municipal sludge as one of the major urban waste solids has been recognized as a complementary P sink [15]. As shown in Fig. 1b, unlike unevenly distributed phosphate rock, municipal sludge is readily available in most countries, with an annual production rate of 1.4-38.7 $\mathrm{kg}$ dry sludge per capita. However, the recovery efficiency of $\mathrm{P}$ directly from municipal sludge is low ( $<50 \%$ of total input) with high costs due to its large volume but low concentrations of $\mathrm{P}$ [16]. On the contrary, sludge requires proper treatment for the increasing amount and potential concerns of contaminants (e.g., pathogens, heavy metals, persistent organic pollutants, and micropollutants) [17]. Every year, a significant amount of municipal sludge requires proper disposal, such as 12.7, 7.8, and 4.0 million dry tonnes in the United States, China, and India, respectively (Fig. 2). Conventional approaches (e.g., land application and landfilling) of municipal sludge treatment are getting increasingly difficult. Land application is considered the best practical option, but it is associated with raised public concerns about pollutants in sludge. Landfilling is widely used in many countries (e.g., Greece, Italy, Iceland, and Malta), while it is restricted due to the concerns of over methane generation and it does not provide opportunities for recovery of organic matters and nutrients in municipal sludge [18]. Thermochemical processes, such as incineration and hydrothermal liquefaction (HTL) are the major alternatives to conventional disposal routes. They have significant advantages, such as deodorization, high efficiency, substantial waste volume reduction ( $\sim 90 \%$ ), organic pollutants destruction, and pathogen deactivation $[19,20]$. More importantly, incineration and HTL generated solid residues (i.e., ash and hydrochar, respectively) are concentrated with P (9-13\% and 4-13\%, respectively) comparable to lowgrade phosphate rock [14,21-23]. A comprehensive assessment considering technological, environmental, and economic aspects has shown that sludge ash could be a more promising source than wastewater and municipal sludge for P recovery $(60-90 \%$ of total wastewater input) [16]. Therefore, using ash or hydrochar as potential $\mathrm{P}$ resources will alleviate the pressing shortage of $\mathrm{P}$ globally.

Incineration of municipal sludge is mostly applied in some European countries (e.g., France, United Kingdom, Germany, Denmark, Netherlands, and Switzerland), Japan, and Hongkong in China because of the health concerns and scarcity of land $[18,19]$. However, an estimation of average costs for sludge management in European countries showed that incineration was the highest (US \$382/dry tonne), compared to direct land application (US \$194-254/dry tonne) and landfilling (US $\$ 309 /$ dry tonne) [24]. Due to the large infrastructural investments (account for half of the total cost) and massive energy demand (primarily for sludge drying), incineration is not an attractive solution in other countries where conventional disposal is still permissible $[21,25,26]$. Although incineration facilities are well-established and reliable, HTL has attracted extensive interest from academics and industries recently for several advantages. First, it converts wet sludge (5-20\% total solids) into energy-dense biocrude for fuel production by processing at a moderate temperature $\left(250-374{ }^{\circ} \mathrm{C}\right)$ and autogenous pressure (4-22 MPa) within a short period (1-60 min) [27]. Second, without drying feedstocks, it is able to generate net-positive energy recovery due to significantly reduced energy inputs and high performance of heat exchanger (up to $80 \%$ heat recovery) $[28,29]$. An economic analysis by Pacific Northwest National Laboratory indicated that deploying HTL into wastewater treatment plants in the US could save biosolids management costs by US $\$ 1.43$ billion/year and total liability of US $\$ 3.46$ billion/year based on current sludge disposal practices (i.e., land application, landfilling, or incineration). Third, compared to high incineration temperatures (e.g., $900{ }^{\circ} \mathrm{C}$ ), reaction temperatures of HTL are much lower and thus decrease the risk of reactor corrosion. Based on our previous literature review [30], the current state of HTL systems is still at pilot-scale requiring further demonstrations, and thus studies related to HTL process will continue to be popular in the next decades. With the ever-increasing stress of depleting fossil fuel and resources (particularly P), building an energy and P recovery system (i.e., coupling HTL and P recovery) is a crucial and sustainable approach.

Ash and hydrochar derived from municipal sludge are accumulated with heavy metals, which could constrain their direct reuse as fertilizers $[31,32]$. Besides, the bioavailability of $\mathbf{P}$ in ash and hydrochar is restricted due to the bound with minerals $[33,34]$. Therefore, removing heavy metals and enhancing the $\mathrm{P}$ bioavailability are the principal goals of $\mathrm{P}$ recovery. The commonly developed $\mathrm{P}$ recovery methods are thermochemical and wet-chemical processes. Thermochemical treatment involves the volatilization of $\mathrm{P}$ with dosed sodium, potassium, or magnesium salts at a reducing atmosphere by heating (typically $900-950{ }^{\circ} \mathrm{C}$ for $15-20 \mathrm{~min}$ ) for producing bioavailable Ca-P [21]. However, this process requires high energy inputs and equipment investment, and inorganic chlorides may be needed to improve heavy metals removal. Wet-chemical technology is more promising than thermochemical processes for its significant advantages: Higher cost-effectiveness, simpler setup, and higher potential for large-scale application [19,31]. It generally involves three steps: Extracting P from solids to liquid, separating $\mathrm{P}$ from hazardous metals, and producing plant-available $\mathrm{P}$ precipitates. The extraction process is mainly classified into two types based on the extractants: Acidic and alkalic. Acids extract $P$ by breaking metal$\mathrm{P}$ bonds that co-leaches heavy metals, although the $\mathrm{P}$ extraction efficiency is high (up to $100 \%$ for $\mathrm{pH}<2$ ). Thus, removal of metals from acidic extracts is often required. Alkalic solutions only extract $\mathrm{P}$ bound 
a)

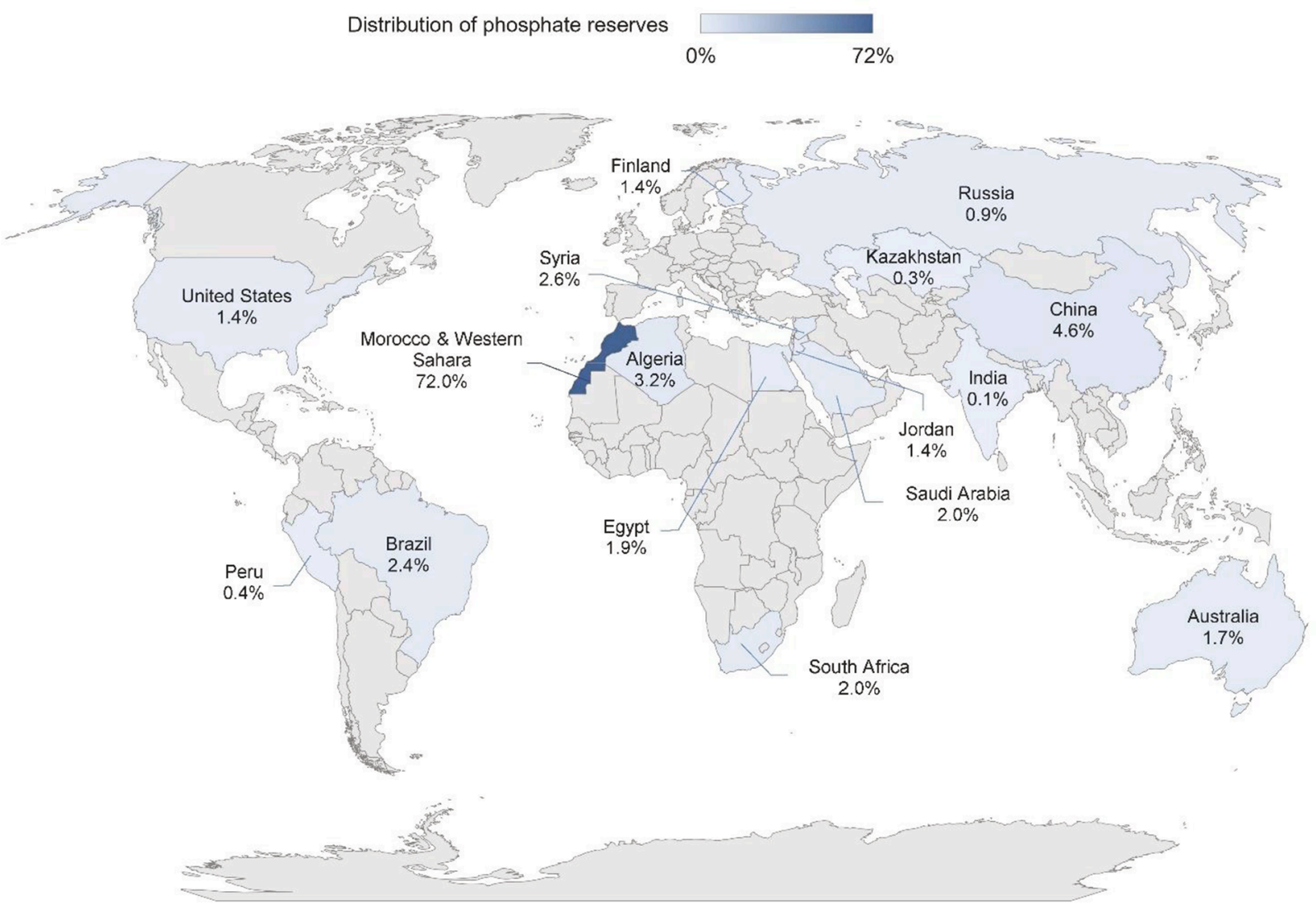

b)

kg dry sludge/year per capita

$1.4 \quad 38.7$

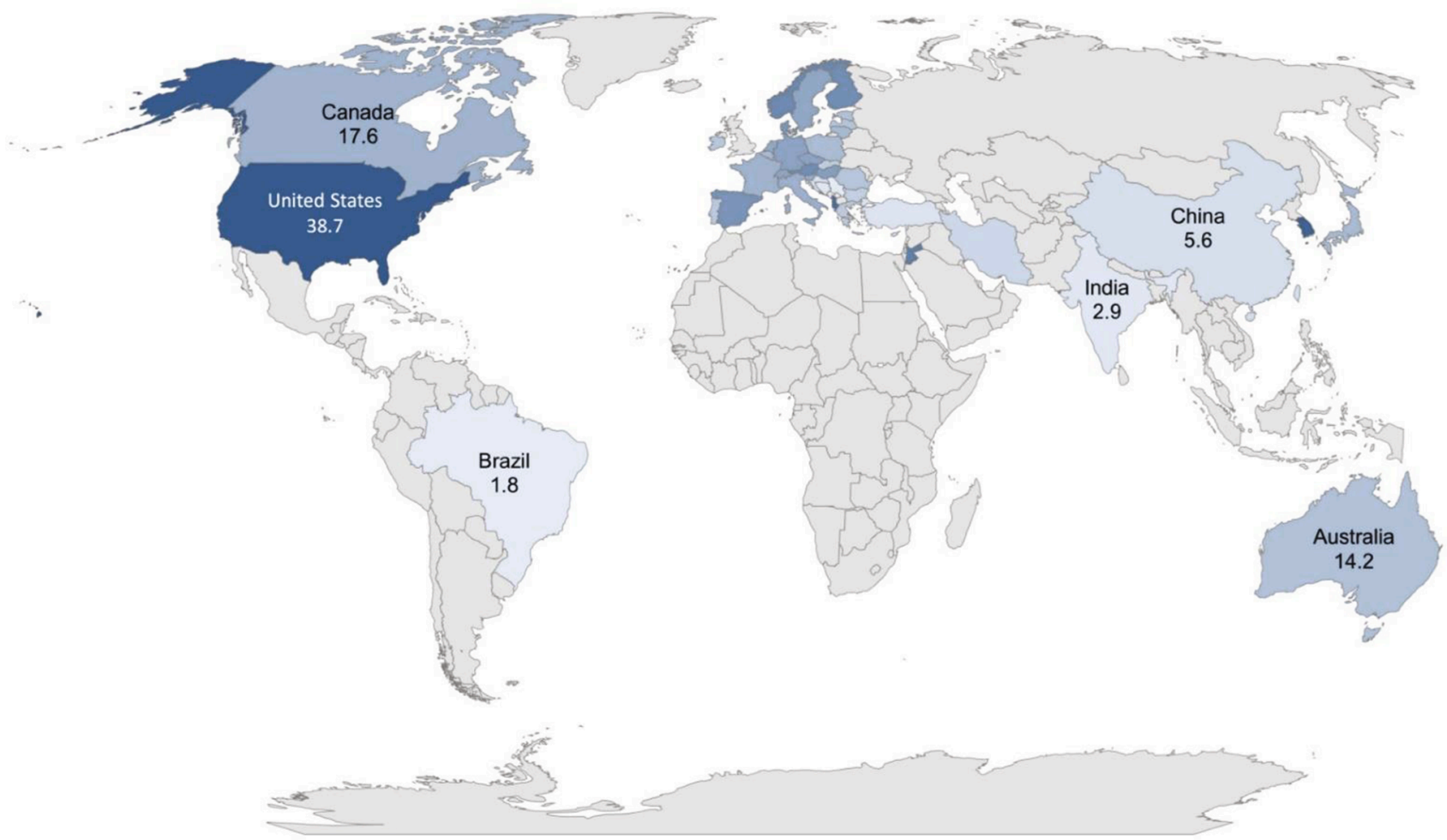

Fig. 1. The distribution estimates of a) global phosphate rock reserves (totally 69 billion tonnes, grey color donates $<0.1 \%$ of total) [7] and b) annual sludge generation per capita in medium- and high-income countries (grey color donates unknown) [10-14]. 


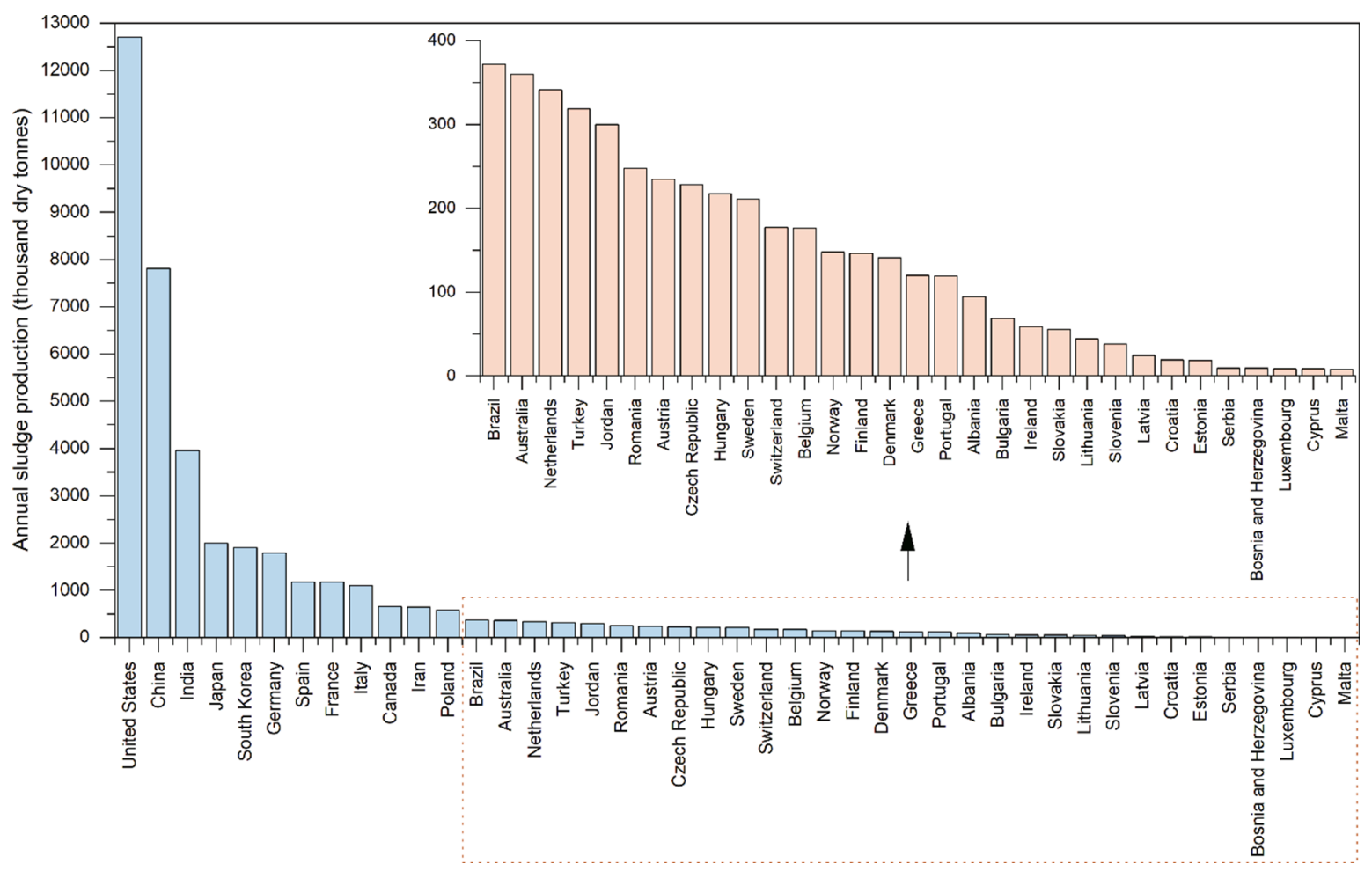

Fig. 2. Annual production of municipal sludge in medium- and high-income countries. Data .

adapted from [10-14]

to amphoteric aluminum and iron, and barely any heavy metals leach under alkalic conditions. Alkalic extraction saves the separation step and downstream processing costs, while the $\mathrm{P}$ extraction efficiency is limited (mostly $<70 \%$ ). $\mathrm{P}$ in both acidic and alkalic extracts is subsequently precipitated and recovered as fertilizers (e.g., struvite, Ca-P, and vivianite).

$\mathrm{P}$ recovery from incinerated sludge ash by wet-chemical techniques has been well studied and applied on the industrial scale (e.g., EcoPhos ${ }^{\circledR}$ and Fertilizer Industry) $[6,16]$. Associated with significant research interests on HTL, an increasing number of studies have focused on P recovery from hydrochar recently [35]. Previous literature has reviewed the necessity and benefits of $P$ recovery $[5,21]$, potential of $P$ recovery from thermal treatment products [33], transformation of $\mathrm{P}$ species during thermal and hydrothermal treatments [9], feasibility of wetextraction of $\mathrm{P}$ from sludge ash [19], $\mathrm{P}$ precipitation processes $[1,2,36-40]$, and full-scale $P$ recovery technologies [41]. To the best of our knowledge, this is the first review about $\mathrm{P}$ recovery from hydrochar. The important advances in the wet-chemical method, sequential extraction for P recovery, is first identified from the literature. Considering the similar characteristics of ash and hydrochar, the insights of $\mathrm{P}$ recovery from ash are likely to support the development of recovery approaches from sludge-derived hydrochar. This review compares the physicochemical properties of ash and hydrochar derived from municipal sludge and summarizes the fundamentals of wet-chemical technologies, providing guidance on $\mathrm{P}$ recovery. It also reveals the feasibility, knowledge gaps, challenges, and recent advances of wetchemical recovery of $\mathrm{P}$ from these two solid residues. Lastly, it emphasizes the construction of sustainable waste management beyond Pbearing ash and hydrochar.

\section{Thermochemical treatment of municipal sludge}

Incineration has been implemented in full scale due to the high calorific value of municipal sludge (8-18 $\mathrm{MJ} / \mathrm{kg}$ dry matter), which neutralizes pathogens and organic matters by complete combustion at
$750-900{ }^{\circ} \mathrm{C}$ with a sludge residence time of seconds $[21,26]$. As shown in Fig. 3, incineration mainly involves sludge drying to achieve selfsustained combustion (sludge total solids content over $30 \%$ by weight), combustion of sludge in an incinerator, heat generation from incineration, ash collection, and cleaning of flue gases (e.g., $\mathrm{CO}, \mathrm{CO}_{2}$,

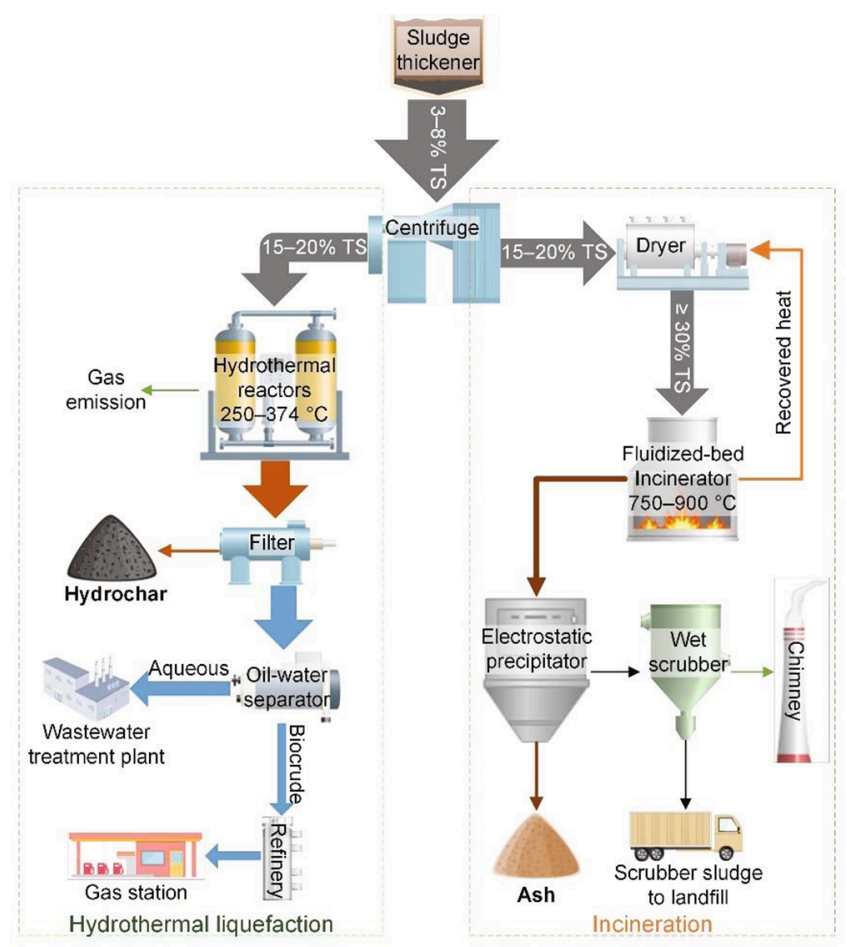

Fig. 3. Overview of the hydrothermal liquefaction and incineration processes $[14,18,26,42]$. TS $=$ total solids in municipal sludge by weight. 
$\mathrm{H}_{2} \mathrm{O}, \mathrm{NO}_{\mathrm{x}}, \mathrm{SO}_{\mathrm{x}}$, and fine particles) $[18,26]$. With the wide use of fluidized-bed incinerator on a large scale, sludge ash residues are mostly $(>99 \%)$ collected as fly ash by the electrostatic precipitator or fabric filter [42]. Due to the significant volume reduction ( $>90 \%)$, most P is concentrated in ash from municipal sludge incineration. However, this process is unlikely to be widely applied for the benefit of $P$ recovery only due to its high investments in incineration facilities, while it is more attractive in countries where land application is restricted, such as the Netherlands and Switzerland [21].

HTL is a hydrothermal process that particularly suits wet biomass waste with high moisture content since it saves the high cost of drying the feedstock as required by other thermochemical methods, e.g., incineration, pyrolysis, and gasification. It works under subcritical conditions with intermediate temperatures and pressures below the critical point of water $\left(374.3^{\circ} \mathrm{C}\right.$ and $\left.22.1 \mathrm{MPa}\right)$ to maintain the reactions in a liquid state [27]. In an enclosed system and the absence of air or oxygen, HTL converts sludge biomass into biocrude that is a liquid mixture of slightly oxygenated hydrocarbons, with a higher heating value of 30-38 MJ/kg, which can be further upgraded and refined as liquid fuel $[14,43]$. As illustrated in Fig. 3, four phases are generated from the HTL of municipal sludge after separation: Biocrude, aqueous phase, hydrochar (solid residue), and gas (mostly $\mathrm{CO}_{2}$ ). A bench-scale continuous-flow HTL treatment achieved a significant solids reduction of $94-98 \%$ by weight for primary, secondary, and digested sludge [14]. The remaining solid phase hydrochar is mainly comprised of mineral ash, char, and some unreacted biomass, where over $80 \%$ of $\mathrm{P}$ from feedstock can be concentrated [15]. Techno-economic analyses have shown the profitable potentials of applying HTL to municipal sludge treatment $[27,44]$. Nutrient recovery from HTL waste streams, such as hydrochar, can add value and improve the environmental and financial sustainability of sludge treatment, and promote the implementation of full-scale HTL into a wastewater treatment plant.

\section{Characteristics of sludge-derived ash and hydrochar}

Following incineration or HTL of municipal sludge, P recovery is affected by the physicochemical properties of the derived ash or hydrochar, such as concentration of $\mathrm{P}$, contents and species co-existing metals/metalloids, $\mathrm{P}$ transformation (speciation) during a thermochemical treatment, and predominant reactions between phosphate and metals/metalloids.

\subsection{Overview of chemical compositions}

The recovery potential of $\mathrm{P}$ from a waste stream is largely dependent on its chemical compositions. First, the value and benefits of waste materials as P sources mainly rely on their P concentrations. Second, the relative abundance of metals (especially those affined with $\mathrm{P}$ ) determines $\mathrm{P}$ species and the complexity of $\mathrm{P}$ recovery processes. Fig. 4 summarizes chemical compositions of ash and hydrochar derived from municipal sludge reported in recent studies. As a comparison, typical compositions of phosphate rock mined from various countries are also presented. As shown in Fig. 4, phosphate rock mainly consists of $\mathrm{P}$ $\left(\mathrm{P}_{2} \mathrm{O}_{5}\right)$ and calcium $(\mathrm{CaO})$, with small amounts of other metals (e.g., $\mathrm{Fe}$ and $\mathrm{Si}$ ), while sludge-derived ash and hydrochar have much more complex compositions. Due to the diverse constituents of municipal sludge and different thermal treatment techniques, the compositions of generated ash and hydrochar vary significantly. Fig. 4b and d present the major elements (mean values) of ash and hydrochar produced in different countries, respectively. Unlike the consistent contents of phosphate rock, mineral concentrations in ash and hydrochar vary considerably in different regions. Therefore, regional-specific $P$ recovery methods should be developed to suit various compositions and avoid likely operational issues (e.g., low efficiency) by directly applying existing processes for phosphate rock. Most studies ( $80 \%$ of collected data, 10-90 percentile range) have found that sludge-derived ash is mainly composed of $\mathrm{Si}\left(\mathrm{SiO}_{2}, 21.2-44.6 \%\right), \mathrm{P}\left(\mathrm{P}_{2} \mathrm{O}_{5}, 13.5-25.7 \%\right), \mathrm{Al}$ $\left(\mathrm{Al}_{2} \mathrm{O}_{3}, 5.6-21.1 \%\right)$, $\mathrm{Ca}(\mathrm{CaO}, 8.4-20.8 \%)$, and $\mathrm{Fe}\left(\mathrm{Fe}_{2} \mathrm{O}_{3}, 4.3-20 \%\right)$, whereas other components (e.g., $\mathrm{MgO}, \mathrm{Na}_{2} \mathrm{O}$, and $\mathrm{K}_{2} \mathrm{O}$ ) are general$1 \mathrm{y}<5 \%$ (Fig. 4c). Similarly, the main elements in sludge-derived hydrochar are also $\mathrm{Si}\left(\mathrm{SiO}_{2}\right), \mathrm{P}\left(\mathrm{P}_{2} \mathrm{O}_{5}, 5.2-13.6 \%\right)$, $\mathrm{Al}\left(\mathrm{Al}_{2} \mathrm{O}_{3}\right.$, 0.6-17\%), $\mathrm{Ca}(\mathrm{CaO}, 1.4-9.2 \%)$, and $\mathrm{Fe}\left(\mathrm{Fe}_{2} \mathrm{O}_{3}, 1.8-13.7 \%\right)$, but in much lower levels compared to ash (note that the content of silica here is not considered representative due to limited data and large variance, Fig. 4e). The smaller concentrations in hydrochar are because ash only contains inorganic matters and little residual carbon $(0.2-6 \%)$ for complete combustion, while a large portion of organics $(12-52 \%$ of volatile matter) and carbon (7-58\%) may remain in hydrochar depending on reaction conditions due to incomplete conversion $[19,45,46]$. If sludge is from enhanced $\mathrm{P}$ removal wastewater treatment process, the precipitation salts (alum, lime, or $\mathrm{FeCl}_{3}$ ) used will increase the contents of $\mathrm{Al}, \mathrm{Ca}$, or $\mathrm{Fe}$, respectively, in ash and hydrochar $[18,47]$. The contents of these minerals (e.g., $\mathrm{Al}, \mathrm{Ca}$, and $\mathrm{Fe}$ ) will eventually determine the $\mathrm{P}$ species in sludge-derived ash and hydrochar, thus affecting the proper $\mathrm{P}$ extraction methods.

Trace elements (particularly heavy metals) in sludge-derived ash and hydrochar are much varied, strongly related to the industrial activities of wastewater sources. Fig. 5 illustrates the concentration distribution of heavy metals present in ash and hydrochar. Among tested samples, most ( $80 \%$ of collected data, $10-90$ percentile range) ash contains abundant Cr (70-1,031 mg/kg), Cu (492-2,500 mg/kg), Ni (44-148 mg/kg), Pb (64-627 mg/kg), and Zn (993-3,810 mg/kg), whereas the concentrations of As (5-54 mg/kg), Cd (2-13 mg/kg) and $\mathrm{Hg}(0.1-3.9 \mathrm{mg} / \mathrm{kg})$ are comparable to phosphate rock (Table 1). A one-year monitoring study found that during sludge incineration most heavy metals (e.g., As, Cd, $\mathrm{Cr}, \mathrm{Cu}, \mathrm{Ni}, \mathrm{Pb}$, and $\mathrm{Zn}$ ) were collected in the electrostatic precipitator as fly ash, except that $80 \%$ of $\mathrm{Hg}$ was lost (in the forms of effluent water, stack gas, and others) [42]. Although As, $\mathrm{Cd}, \mathrm{Hg}$, and $\mathrm{Pb}$ are anticipated to volatilize during combustion, they tend to condense on ash surfaces when temperature falls in the collector [18]. Another study reported that most P (nearly 89\%) was distributed in bottom ash when the incineration temperature was controlled below $950{ }^{\circ} \mathrm{C}$ [76]. Sludgederived hydrochar is also found to be concentrated with $\mathrm{Cr}$ (78-971 $\mathrm{mg} / \mathrm{kg}), \mathrm{Cu}(162-2,510 \mathrm{mg} / \mathrm{kg}), \mathrm{Ni}(32-600 \mathrm{mg} / \mathrm{kg}), \mathrm{Pb}(37-121 \mathrm{mg} /$ $\mathrm{kg})$, Zn (500-3,147 mg/kg), as well as $\mathrm{Hg}(0.2-72 \mathrm{mg} / \mathrm{kg})$, plus some As $(2.7-29 \mathrm{mg} / \mathrm{kg})$ and $\mathrm{Cd}(1.1-4.4 \mathrm{mg} / \mathrm{kg})$. Previous studies have proven that most heavy metals, including $\mathrm{Hg}$, accumulate in hydrochar during the hydrothermal conversion of municipal sludge [15,32,34,72,77-81]. The high concentrations of heavy metals are the primary concerns when developing P extraction methods for ash and hydrochar. Since the above-mentioned heavy metals are regulated by fertilizer ordinance in various countries, minimizing their co-extraction could reduce the subsequent processing costs (e.g., separation of $\mathrm{P}$ from heavy metals).

For some heavy metals (e.g., Cr and As), chemical states are more important than total concentrations in determining their toxicity, raising more concerns in using the produced fertilizers $[88,89]$. Studies suggested that more stable and less toxic $\mathrm{Cr}(\mathrm{III})$ was dominant in sludgederived ash, while the toxic $\mathrm{Cr}(\mathrm{VI})$ was only $0.1 \mathrm{mg} / \mathrm{kg}$, even less than that in phosphate rock $(0.5 \mathrm{mg} / \mathrm{kg})$ and triple superphosphate fertilizer $(0.7 \mathrm{mg} / \mathrm{kg})[57,58,90]$. Takaoka et al. also found that more mobile and hazardous As(III) was completely transformed into $\mathrm{As}(\mathrm{V})$ in sludgederived ash after incineration [58]. However, Zhao et al. found that As(III) accounts for over $50 \%$ of As in fly ash from combustion of municipal sludge at $900{ }^{\circ} \mathrm{C}$, with a concentration comparable to that in phosphate rock (2.1-5.5 mg/kg) [91-93]. To date, the chemical states of these heavy metals in sludge-derived hydrochar remain unknown. Heavy metal removal is necessary to produce public-acceptable P fertilizers from ash, hydrochar, and phosphate rock. The advantage of using sludge-derived ash and hydrochar is that they are readily available in all countries. 

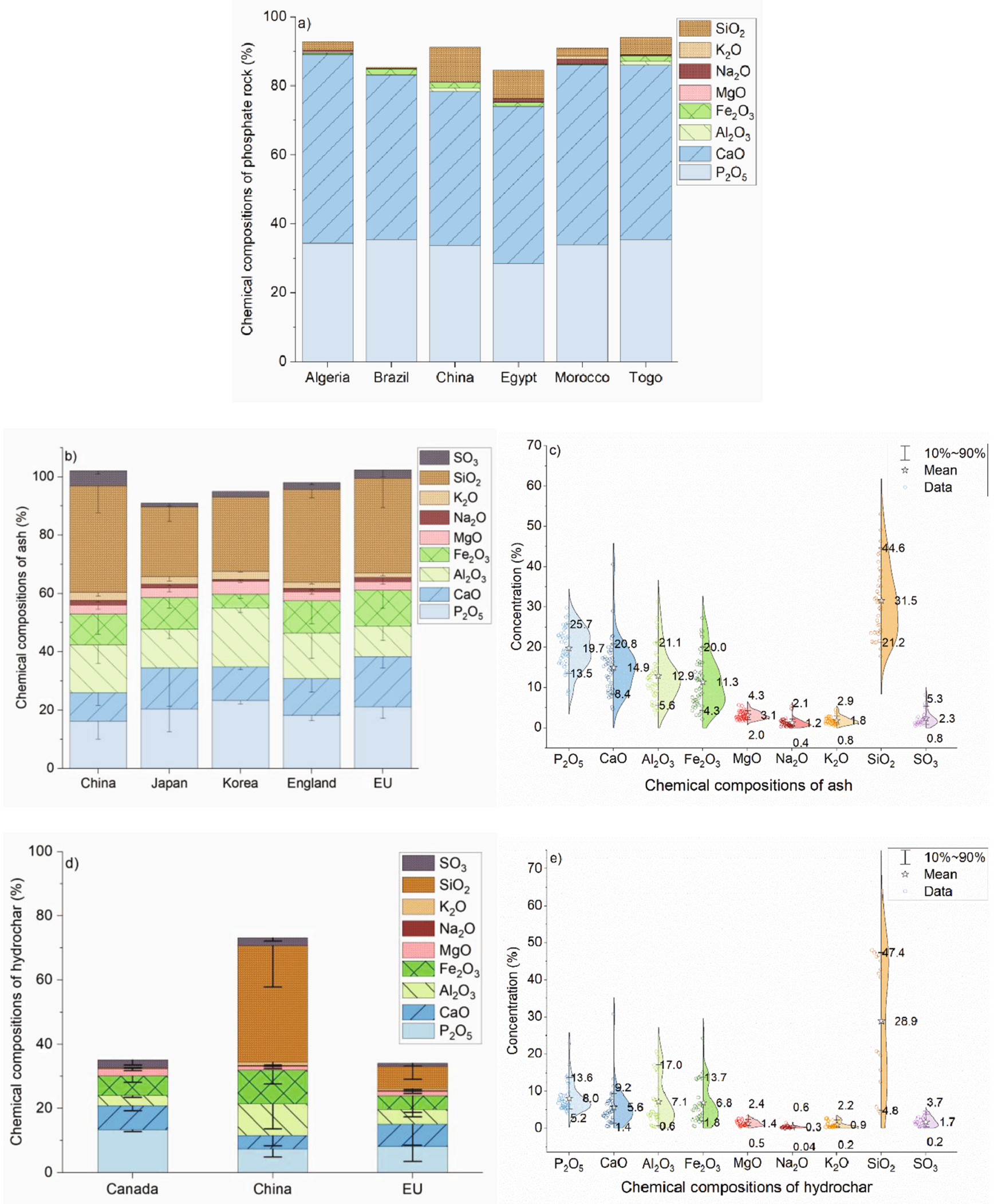

Fig. 4. Chemical compositions of phosphate rock and sludge-derived ash and hydrochar: (a) typical compositions of phosphate rock from various countries [6,48]; (b) mean values and (c) violin distribution of ash compositions [6,31,48-67]; (d) mean values and (e) violin distribution of hydrochar compositions $[14,15,22,23,28,32,45,68-75]$. EU = European Union (data from Belgium, Denmark, Germany, Poland, Spain, Sweden, and Switzerland). 

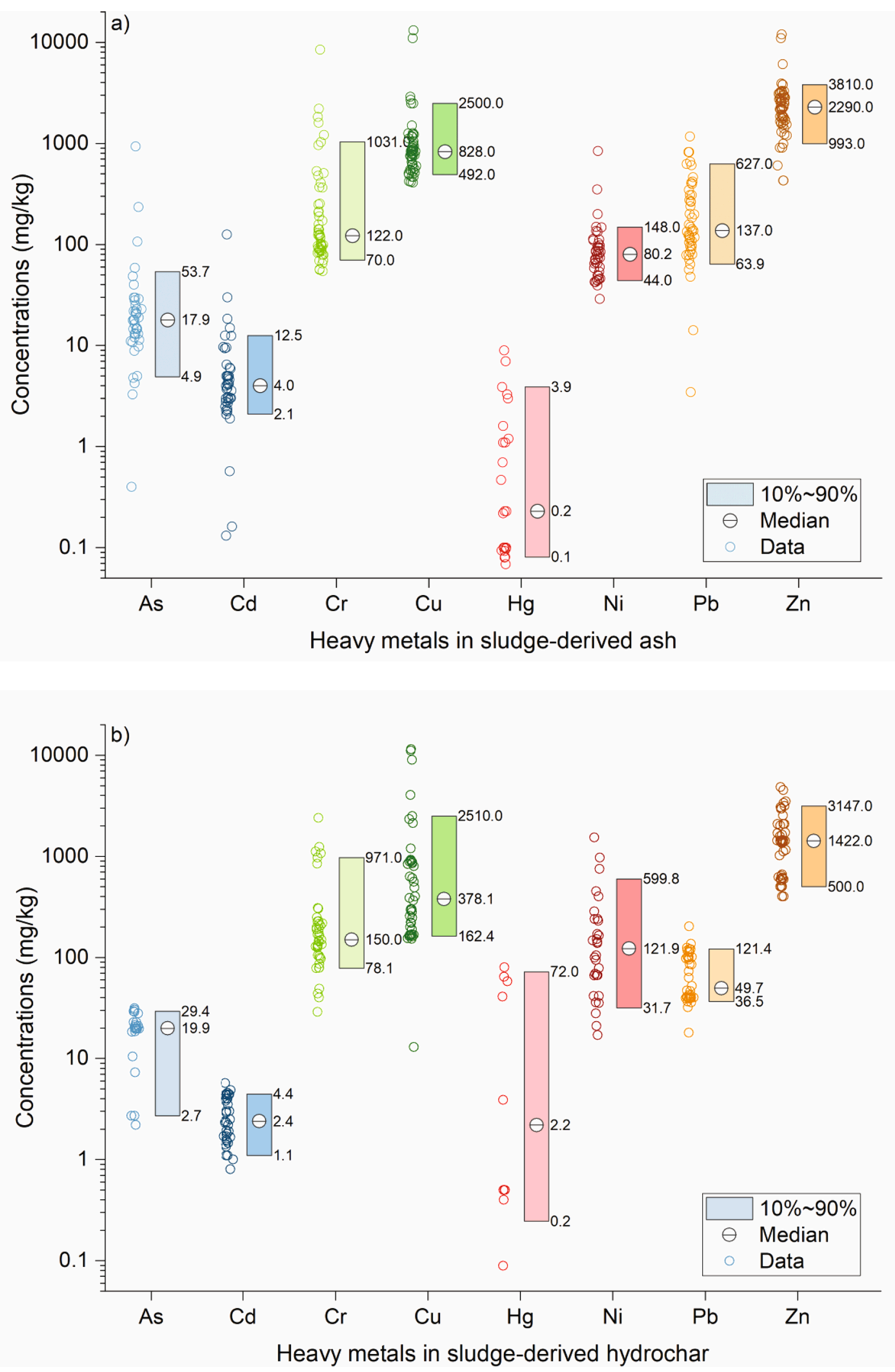

Fig. 5. Distribution plot of heavy metals in (a) sludge-derived ash $[6,31,48,50-55,57-67,82,83]$ and (b) sludge-derived hydrochar $[14,15,23,28,32,45,68,69,72,74,75,79,84-87]$. 
Table 1

Concentrations $(\mathrm{mg} / \mathrm{kg})$ of heavy metals in phosphate rock from various regions $[6,48]$.

\begin{tabular}{|c|c|c|c|c|c|c|c|c|c|}
\hline Country & As & $\mathrm{Cd}$ & $\mathrm{Cr}$ & $\mathrm{Cu}$ & $\mathrm{Hg}$ & $\mathrm{Ni}$ & $\mathrm{Pb}$ & $\mathrm{Zn}$ & $\mathrm{U}$ \\
\hline China & $9-26$ & $0-2.5$ & $18-33$ & - & $0.005-0.211$ & - & $1.5-6$ & - & $23-31$ \\
\hline Morocco & $1.3-13$ & $15-38$ & $75-291$ & $1-22$ & $0.04-0.855$ & 26 & $7-30.1$ & $172-345$ & 75-155 \\
\hline Middle East & $2.4-35$ & $1.5-35$ & $25-230$ & $5-31$ & $0.002-0.02$ & $20-80$ & $1-33$ & 29-630 & $40-170$ \\
\hline Russia & $1-10$ & $0.1-1.3$ & $13-23$ & $15-30$ & $0.004-0.01$ & $2-15$ & $1.8-33$ & $19-23$ & $10-85$ \\
\hline US & $7-14$ & $6.1-92$ & $60-637$ & $9.6-23$ & $0.05-0.233$ & $17-37$ & $4.6-17$ & 204-403 & $65-180$ \\
\hline
\end{tabular}

\subsection{Transformation of $P$ species}

The Standards, Measurements, and Testing (SMT) Protocol has been widely used to determine $\mathrm{P}$ species $[94,95]$. P in solids can exist as inorganic P (IP) and organic P (OP). By extracting with $\mathrm{HCl}$ or $\mathrm{NaOH}$ solutions, IP can be classified as apatite phosphate (AP) and non-apatite inorganic phosphate (NAIP), respectively. NAIP is mainly in the form of $\mathrm{Al}, \mathrm{Fe}, \mathrm{Mg}$, and Mn oxides and hydroxides, while AP is primarily bound to $\mathrm{Ca}$ [62]. Fig. 6a and b display P speciation in sludge-derived ash and hydrochar under various incineration and hydrothermal conditions, respectively. Ash only contains IP because of complete combustion, whereas hydrochar may retain negligible OP from municipal sludge. Although the concentration of AP in ash slightly increases with increasing temperature, the changes of AP and NAIP are not significant except at higher temperatures (e.g., $950{ }^{\circ} \mathrm{C}$ ). The dramatic loss of NAIP at $950{ }^{\circ} \mathrm{C}$ may be caused by its high volatilization, while AP is more stable at high incineration temperature $[49,76]$. The AP amount in hydrochar also rises gradually with enhanced hydrothermal temperature, but it seems that the P species are largely affected by other treatment conditions (e.g., residence time, solids content, and liquid chemistry) [9]. Shi et al. found that AP and NAIP were equal in hydrochar produced at $320{ }^{\circ} \mathrm{C}$ for $0.5 \mathrm{~h}$ [15], whereas Zhai et al. reported almost only AP was present in hydrochar obtained at 350 and $400{ }^{\circ} \mathrm{C}$ for $0.5 \mathrm{~h}$ [96]. The content of NAIP implies the maximum extractable $\mathrm{P}$ by direct alkalic extraction for $\mathrm{P}$ recovery. Higher reaction temperatures for incineration and HTL are likely to transform NAIP to AP in ash and hydrochar, which reduces the feasibility of alkalic extraction method.

The molecular moieties of $\mathrm{P}$ in sludge-derived ash and hydrochar are relatively simple according to the ${ }^{31} \mathrm{P}$ nuclear magnetic resonance (NMR) spectra. Qian and Jiang found that various P species (orthophosphate monoesters, orthophosphate diesters, and pyrophosphate) in municipal sludge were all transformed into orthophosphate in ash when combustion temperature was over $600{ }^{\circ} \mathrm{C}$ [101]. Nanzer et al. investigated four types of sludge-derived ash samples from mono-combustion plants and only observed the presence of orthophosphate [102]. Due to the dehydration of $\mathrm{M}_{2}\left(\mathrm{HPO}_{4}\right)_{\mathrm{x}}$ or $\mathrm{M}\left(\mathrm{H}_{2} \mathrm{PO}_{4}\right)_{\mathrm{x}}$ ( $\mathrm{M}$ - metals) and degradation of polyphosphates in sludge, a considerable amount of pyrophosphate might be formed in ash produced at medium temperature ranges $\left(300-600{ }^{\circ} \mathrm{C}\right)[101-103]$. However, it was reported that high incineration temperatures $\left(700-900{ }^{\circ} \mathrm{C}\right)$ could prohibit the formation of pyrophosphates [101]. For hydrochar, Li et al. and Shi et al. also reported that orthophosphate was dominant ( $>90 \%$ of total P), and other forms of P (e.g., orthophosphate monoester and pyrophosphate) gradually disappeared with increasing hydrothermal temperature at $260{ }^{\circ} \mathrm{C}$ $(4 \mathrm{~h})$ and $320^{\circ} \mathrm{C}(0.5 \mathrm{~h})$, respectively [15,97]. Even at a low hydrothermal temperature $\left(225{ }^{\circ} \mathrm{C}\right.$ for $\left.24 \mathrm{~h}\right)$, pyrophosphate can be totally converted into orthophosphate [103]. The improved purity of orthophosphate and inhibition of pyrophosphate formation by controlling reaction temperatures are beneficial for precipitation recovery after wetchemical extraction.

\subsection{P complexation and mineralogy}

Due to the predominance of $\mathrm{Al}, \mathrm{Ca}$ and $\mathrm{Fe}$ in sludge-derived ash and hydrochar, P exists in the forms of solid precipitates (e.g., metal phosphate salts) and mineral-adsorbed phases [104]. P K-edge X-ray absorption near edge structure (XANES) is an advanced technique that has been applied to determine the complexation and mineralogy of $\mathrm{P}$. For sludge-derived ash, one study found the $\mathrm{P}$ speciation varied depending on the abundance of $\mathrm{Al}, \mathrm{Ca}$, and $\mathrm{Fe}$ : Crystalline or amorphous variscite $\left(\mathrm{AlPO}_{4} \cdot 2 \mathrm{H}_{2} \mathrm{O}\right)$ was dominant $(87 \%$ of total $\mathrm{P})$ in $\mathrm{Al}$-rich ash; $\mathrm{P}$ was mainly $\beta$-tricalcium phosphate $\left[\mathrm{Ca}_{3}\left(\mathrm{PO}_{4}\right)_{2}, 65 \%\right.$ of total $\left.\mathrm{P}\right]$ or sorbed to calcite ( $20 \%$ of total P) in Ca-rich ash; however, no ash sample showed the presence of iron phosphates (Fe-P) even in Fe-rich ash, which was also confirmed by the ${ }^{31} \mathrm{P}$ NMR analysis [102]. Vogel et al. identified $\mathrm{Fe}_{3}\left(\mathrm{PO}_{4}\right)_{2}$ as the major iron form in a Fe-rich (19\% by weight) ash using the Fe K-edge XANES spectra [57]. For sludge-derived hydrochar, various $\mathrm{P}$ fractions could be detected. Shi et al. reported that Ca-P, such as hydroxyapatite $\left[\mathrm{Ca}_{5}\left(\mathrm{PO}_{4}\right)_{3} \mathrm{OH}\right]$ and octacalcium phosphate $\left[\mathrm{Ca}_{8} \mathrm{H}_{2}\left(\mathrm{PO}_{4}\right)_{6} \cdot 5 \mathrm{H}_{2} \mathrm{O}\right.$ ], became more dominant (57\% to $80 \%$ of total $\mathrm{P}$ ) in hydrochar with increasing hydrothermal temperature from 170 to $320{ }^{\circ} \mathrm{C}$, while other forms, e.g., $\mathrm{FePO}_{4}, \mathrm{Mg}_{2}\left(\mathrm{PO}_{4}\right)_{3}$ and $\mathrm{AlPO}_{4}$, reduced from $43 \%$ to $20 \%$ [15]. The hydrochar samples were also found to be $\mathrm{Al} / \mathrm{Ca} / \mathrm{Fe} / \mathrm{Mg}$ abundant ( $\mathrm{Ca}>\mathrm{Fe}>\mathrm{Mg}>\mathrm{Al}$ ) [15]. From a waste activated sludge with $3.6 \% \mathrm{Fe}$ and $2.4 \% \mathrm{Al}$ by weight, $\mathrm{AlPO}_{4}$ was the major form (43\% of total P) in hydrochar (treated at $225{ }^{\circ} \mathrm{C}$ for $4 \mathrm{~h}$ ), whereas both aluminum phosphate (Al-P: $\mathrm{AlPO}_{4}$ and alumina-adsorbed, $38 \%$ of total $\mathrm{P}$ ) and ferrihydrite-adsorbed $\mathrm{P}(27 \%$ of total $\mathrm{P})$ became the majority in hydrochar derived from digested sludge with a much higher Fe content $(9.1 \%)$ [104]. Another study observed the dominance of strengite $\left(\mathrm{FePO}_{4} \cdot 2 \mathrm{H}_{2} \mathrm{O}, 42 \%\right.$ of total $\left.\mathrm{P}\right), \mathrm{Al}-\mathrm{P}\left(\mathrm{AlPO}_{4}\right.$ and aluminaadsorbed, $34 \%$ of total $\mathrm{P}$ ), and Ca-P (hydroxyapatite and octacalcium phosphate, $21 \%$ of total $\mathrm{P}$ ) in hydrochar obtained at $185^{\circ} \mathrm{C}$ for $4 \mathrm{~h}$ from digested sludge [105]. It was also found that higher temperature $\left(>155{ }^{\circ} \mathrm{C}\right.$ ) promoted the oxidation of $\mathrm{Fe}_{3}\left(\mathrm{PO}_{4}\right)_{2}$ to $\mathrm{FePO}_{4}$ in hydrochar [105].

X-ray diffraction (XRD) has been widely used to analyze the crystallized phases in sludge-derived ash and hydrochar. Most studies found that major crystalline compounds in sludge-derived ash were quartz $\left(\mathrm{SiO}_{2}\right)$, hematite $\left(\mathrm{Fe}_{2} \mathrm{O}_{3}\right)$, and whitlockite or whitlockite-like compounds $\left[\mathrm{Ca}_{9} \mathrm{X}\left(\mathrm{PO}_{4}\right)_{7}, \mathrm{X}=\mathrm{Al} / \mathrm{Fe} / \mathrm{Mg}\right][31,48,50-52,59,64,66,106-109]$. Whitlockite can be readily dissolvable in both organic and inorganic acids but can be barely dissolved by alkalic and chelating agents (e.g., EDTA) $[52,64,107]$. In Al-rich ash, $\mathrm{AlPO}_{4}$ (crystallographically disordered) was also commonly detected by $\mathrm{XRD}$, which is alkaline-soluble $[102,106,109]$. Nanzer et al. identified $\mathrm{AlPO}_{4}$, whitlockite, and hydroxyapatite as the major crystalline $\mathrm{P}$ phase in $\mathrm{Al}$-rich, Fe-rich, and Carich ashes, respectively [102]. It was also found that more $\mathrm{Ca}_{3}\left(\mathrm{PO}_{4}\right)_{2}$ and less $\mathrm{AlPO}_{4}$ could be detected with increasing incineration temperature (from 675 to $950{ }^{\circ} \mathrm{C}$ ) [49,76]. For sludge-derived hydrochar, quartz $\left(\mathrm{SiO}_{2}\right)$ has also been found as the main crystalline compound $[22,98,100,110-113]$. However, crystalline P phases in hydrochar vary depending on the sludge properties and hydrothermal conditions. Acelas et al. observed the presence of whitlockite, $\mathrm{AlPO}_{4}$, and hydroxyapatite in hydrochar generated under $600{ }^{\circ} \mathrm{C}$ for $1 \mathrm{~h}$ [110]. Yu et al. found that $\mathrm{P}$ minerals were highly associated with the predominance of $\mathrm{Al}, \mathrm{Ca}$, and $\mathrm{Fe}$ in hydrochar [111]. Xu et al. only detected $\mathrm{Ca}_{7} \mathrm{Mg}_{2}\left(\mathrm{PO}_{4}\right)_{6}$ as the crystallized $\mathrm{P}$ in Ca-rich hydrochar $\left(260{ }^{\circ} \mathrm{C}\right.$ for $\left.4 \mathrm{~h}\right)$ [98]. Zheng et al. reported $\mathrm{AlPO}_{4}$ as the main fraction in hydrochar $\left(280^{\circ} \mathrm{C}\right.$ for $\left.1 \mathrm{~h}\right)$, with the identification of other types (Ca-P and Fe-P) $[100,112]$. Another study also showed the dominance of $\mathrm{AlPO}_{4}$ regardless of the hydrothermal 

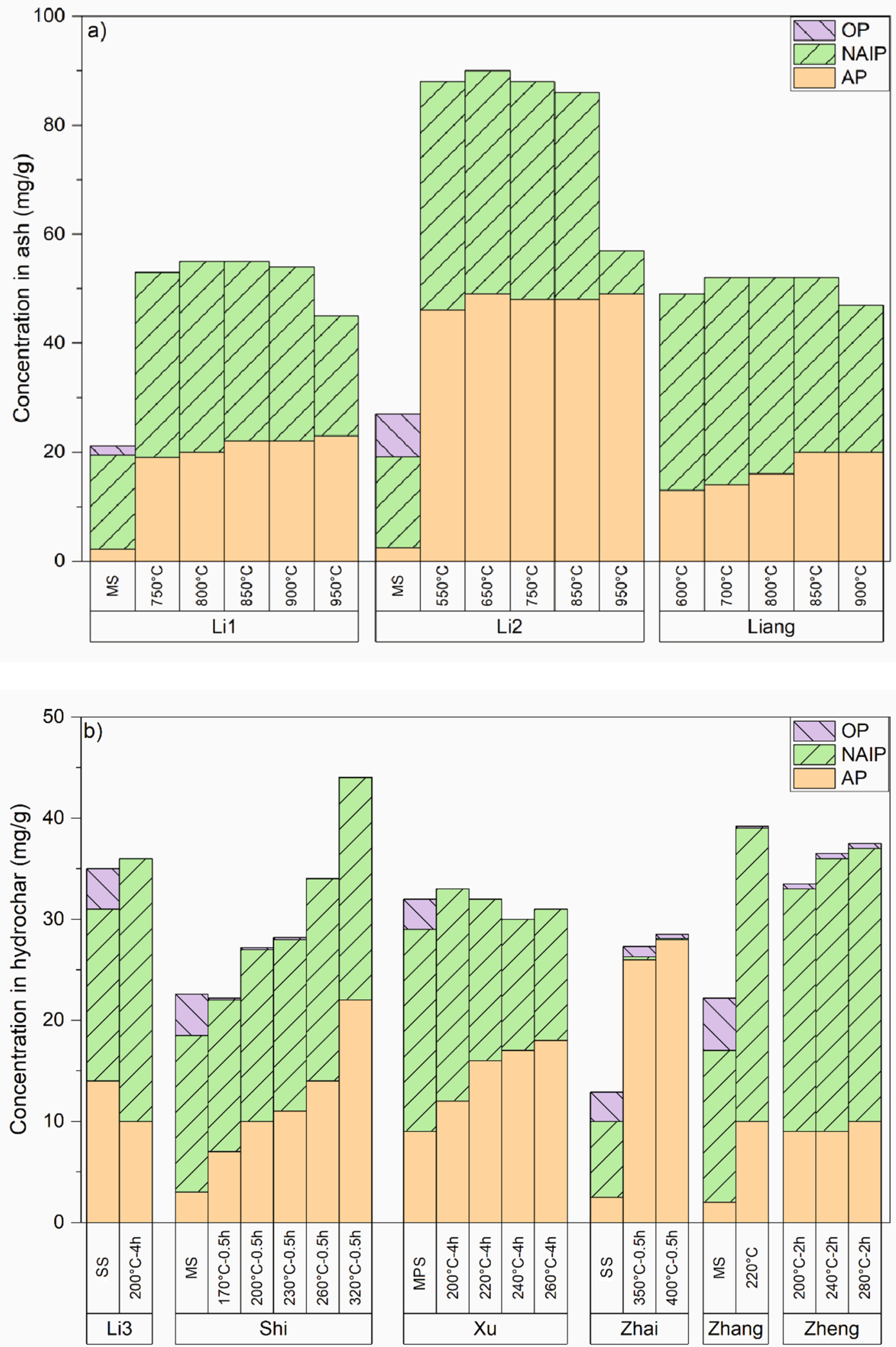

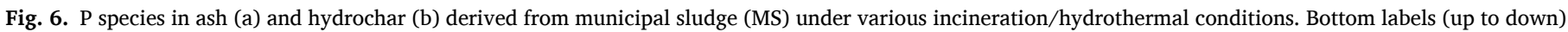

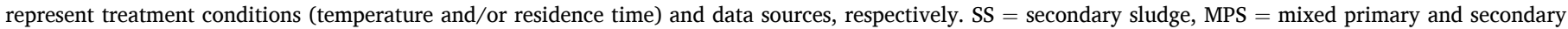

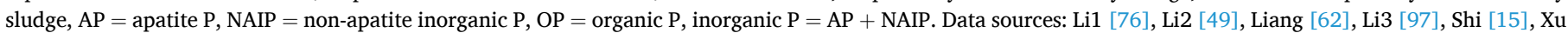
[98], Zhai [96], Zhang [99], and Zheng [100]. 
conditions $\left(\mathrm{pH}=3-11\right.$ at $200-260^{\circ} \mathrm{C}$ for $2 \mathrm{~h}$ ) due to much higher $\mathrm{Al}$ contents than other metals [113]. Due to the low concentrations in sludge-derived ash and hydrochar, most studies did not report the detection of crystallized heavy metals by XRD.

Both thermochemical processes (i.e., incineration and hydrothermal conversion) cause the formation of more stable and insoluble $\mathrm{P}$, with the final $\mathrm{P}$ complexes closely associated with the speciation/abundance of $\mathrm{P}$ binding metals/minerals (e.g., $\mathrm{Al}, \mathrm{Ca}, \mathrm{Fe}$, and $\mathrm{Mg}$ ). In $\mathrm{Al}$ - and Ca-rich ash/hydrochar, $\mathrm{AlPO}_{4}$ and Ca-P (e.g., $\beta$-tricalcium phosphate and hydroxyapatite) tend to predominate P-binding compounds, respectively. $\mathrm{FePO}_{4}$ could be the primary form in Fe-rich hydrochar. Increasing incineration or hydrothermal temperatures also favor the formation of more stable Ca-P (i.e., apatite) while reducing the formation of Al-P and Fe-P in sludge-derived ash and hydrochar.

\section{Wet-chemical extraction of $P$}

The wet-chemical extraction for P recovery can be distinguished as acidic and alkalic extraction methods. Due to the high concentrations of metals and complex compositions of sludge-derived ash and hydrochar, it is likely to cause operational issues or suboptimal extraction efficiencies using conventional extraction methods. The following sections summarize the optimization processes and recent advances in $\mathrm{P}$ extraction.

\subsection{Acidic extraction}

Acidic extraction is the most used wet-chemical method for $\mathrm{P}$ recovery due to its high extraction efficiency. Both inorganic and organic acids have been used for $\mathrm{P}$ recovery from sludge-derived ash and hydrochar. Inorganic acids include hydrochloric acid $\left(\mathrm{HCl}, \mathrm{K}_{\mathrm{a}}=1.3 \times\right.$ $\left.10^{6}\right)$, sulfuric acid $\left(\mathrm{H}_{2} \mathrm{SO}_{4}, \mathrm{~K}_{\mathrm{a} 1}=1 \times 10^{3}\right)$, nitric acid $\left(\mathrm{HNO}_{3}, \mathrm{~K}_{\mathrm{a}}=24\right)$, and phosphoric acid $\left(\mathrm{H}_{3} \mathrm{PO}_{4}, \mathrm{~K}_{\mathrm{a} 1}=7.1 \times 10^{-3}\right)$, while organic acids involve oxalic acid $\left(\mathrm{C}_{2} \mathrm{H}_{6} \mathrm{O}_{6}, \mathrm{~K}_{\mathrm{a} 1}=5.9 \times 10^{-2}\right)$, citric acid $\left(\mathrm{C}_{6} \mathrm{H}_{8} \mathrm{O}_{7}, \mathrm{~K}_{\mathrm{a} 1}\right.$ $\left.=8.4 \times 10^{-3}\right)$, gluconic acid $\left(\mathrm{C}_{6} \mathrm{H}_{12} \mathrm{O}_{7}, \mathrm{~K}_{\mathrm{a} 1}=2.5 \times 10^{-4}\right)$, formic acid $\left(\mathrm{CH}_{2} \mathrm{O}_{2}, \mathrm{~K}_{\mathrm{a}}=1.8 \times 10^{-4}\right)$, and acetic acid $\left(\mathrm{C}_{2} \mathrm{H}_{4} \mathrm{O}_{2}, \mathrm{~K}_{\mathrm{a}}=1.8 \times 10^{-5}\right)$. These inorganic acids have been proven for their high $\mathrm{P}$ extraction capacity by dissolving alkali-metal oxides and leaching $\mathrm{P}$ contained in most phases, while organic acids facilitate the release of metals/metalloids and metal-bound $P$ by inducing chelating effects [64]. Considering that $\mathrm{P}$ in ash and hydrochar dominantly exists as Ca-P, Al-P, and Fe-P, the potential reactions (simplified) during $P$ extraction by acids are listed in Eqs. (1)-(6) $[31,52]$. However, it should be noted that P compounds are often present in more complex forms (e.g., whitlockite). Among these acids, $\mathrm{H}_{2} \mathrm{SO}_{4}$ is mostly employed at a commercial scale for its low cost.

$$
\begin{aligned}
& \mathrm{AlPO}_{4}+3 \mathrm{H}^{+} \rightleftharpoons \mathrm{Al}^{3+}+\mathrm{H}_{3} \mathrm{PO}_{4}, \mathrm{~K}_{\mathrm{sp}}=9.8 \times 10^{-21} \\
& \mathrm{FePO}_{4}+3 \mathrm{H}^{+} \rightleftharpoons \mathrm{Fe}^{3+}+\mathrm{H}_{3} \mathrm{PO}_{4}, \mathrm{~K}_{\mathrm{sp}}=1.3 \times 10^{-22} \\
& \mathrm{Ca}_{3}\left(\mathrm{PO}_{4}\right)_{2}+6 \mathrm{H}^{+} \rightleftharpoons 3 \mathrm{Ca}^{2+}+2 \mathrm{H}_{3} \mathrm{PO}_{4}, \mathrm{~K}_{\mathrm{sp}}=2.1 \times 10^{-33} \\
& \mathrm{Fe}_{3}\left(\mathrm{PO}_{4}\right)_{2}+6 \mathrm{H}^{+} \rightleftharpoons 3 \mathrm{Fe}^{2+}+2 \mathrm{H}_{3} \mathrm{PO}_{4}, \mathrm{~K}_{\mathrm{sp}}=1.6 \times 10^{-36} \\
& \mathrm{Ca}_{3}\left(\mathrm{PO}_{4}\right)_{2}+3 \mathrm{H}_{2} \mathrm{SO}_{4} \rightleftharpoons 3 \mathrm{CaSO}_{4} \downarrow+2 \mathrm{H}_{3} \mathrm{PO}_{4} \\
& \mathrm{Ca}_{3}\left(\mathrm{PO}_{4}\right)_{2}+3 \mathrm{H}_{2} \mathrm{C}_{2} \mathrm{O}_{4} \rightleftharpoons 3 \mathrm{CaC}_{2} \mathrm{O}_{4} \downarrow+2 \mathrm{H}_{3} \mathrm{PO}_{4}
\end{aligned}
$$

With the use of $\mathrm{H}_{2} \mathrm{SO}_{4}$ and $\mathrm{H}_{2} \mathrm{C}_{2} \mathrm{O}_{4}$, hardly soluble gypsum ( $\mathrm{CaSO}_{4}$, $\left.\mathrm{K}_{\mathrm{sp}}=4.9 \times 10^{-5}\right)$ and calcium oxalate $\left(\mathrm{CaC}_{2} \mathrm{O}_{4}, \mathrm{~K}_{\mathrm{sp}}=2.3 \times 10^{-9}\right)$ have been identified on the particle surfaces of acid-extracted sludge ash, respectively [107]. These reactions (Eqs. (5) and (6)) could enhance the dissolution of Ca-P. On the other hand, P leaching efficiency might be decreased with time due to the physical barrier formed by the deposition of $\mathrm{CaSO}_{4}$ and $\mathrm{CaC}_{2} \mathrm{O}_{4}$ on ash particles [31]. Besides, the formation of $\mathrm{CaSO}_{4}$ could increase the waste volume and constrain the possible reuse of acid-washed ash as a construction material, since gypsum would affect the early hydration chemistry and setting time and reduce the strength development of Portland cement $[107,114]$. On the contrary, $\mathrm{CaC}_{2} \mathrm{O}_{4}$ is not expected to negatively affect cement properties as organic fraction shall be combusted in a cement kiln [31].

Based on the stoichiometric calculations of Eqs. (1)-(6), if the molar ratio of $\mathrm{H}^{+} / \mathrm{P}$ equals 3 , P should be completely extracted by acid solutions. However, due to the presence of other acid-soluble compounds, such as oxides of alkali and alkaline earth metals, a greater amount of acid is required to extract almost all $\mathrm{P}$ from ash and hydrochar [52]. Fig. 7a shows the low correlation (adjusted $R^{2}=0.29$ ) between $P$ extraction efficiency and $\mathrm{H}^{+} / \mathrm{P}$ molar ratio for acidic extraction, indicating that using $\mathrm{H}^{+} / \mathrm{P}$ is inadequate to estimate the required amount of acid due to varied characteristics of ash and hydrochar. A stoichiometric equation (Eq. (7)) based on the mineral compositions (\%) of phosphate rock was proposed by the US Department of Agriculture [115], and it can be used to more accurately estimate the required amount of $100 \%$ sulfuric acid (kg) per $100 \mathrm{~kg}$ of dry material (ash or hydrochar). It should be noted that the estimation assumes that fluorine does not interfere with acid extraction. As demonstrated by Fig. $7 \mathrm{~b}$, the predicted $\mathrm{P}$ extraction efficiency based on the required amount of $\mathrm{H}_{2} \mathrm{SO}_{4}$ (calculated by Eq. (7)) is linearly correlated (adjusted $\mathrm{R}^{2}=0.82$ ) with the actual extraction efficiency. Therefore, Eq. (7) can be used to estimate the acid demands when using $\mathrm{H}_{2} \mathrm{SO}_{4}$ for $\mathrm{P}$ extraction from sludge-derived ash and hydrochar.

$$
\begin{aligned}
\mathrm{H}_{2} \mathrm{SO}_{4}(\mathrm{~kg} / 100 \mathrm{~kg} \text { dry material })= & 1.749(\mathrm{CaO} \%)+0.962\left(\mathrm{Al}_{2} \mathrm{O}_{3} \%\right) \\
& +0.614\left(\mathrm{Fe}_{2} \mathrm{O}_{3} \%\right)+2.433(\mathrm{MgO} \%) \\
& +1.582\left(\mathrm{Na}_{2} \mathrm{O} \%\right)+1.041\left(\mathrm{~K}_{2} \mathrm{O} \%\right) \\
& -0.691\left(\mathrm{P}_{2} \mathrm{O}_{5} \%\right)-1.225\left(\mathrm{SO}_{3} \%\right)
\end{aligned}
$$

\subsubsection{Influential factors for $P$ extraction}

Along with the chemical dosage, many process parameters can affect $P$ extraction efficiency. These factors include compositions of ash and hydrochar, type and concentration of extractant, solution $\mathrm{pH}$, liquid to solid (L/S) ratio, contact time, agitation, extraction temperature, and upstream treatment variables (e.g., incineration and HTL conditions). It has been reported that although increasing aqueous temperature from 30 to $70{ }^{\circ} \mathrm{C}$ could slightly $(<1 \%)$ enhance $\mathrm{P}$ extraction efficiency, it leached more metals (e.g., $\mathrm{Ca}, \mathrm{Cu}, \mathrm{Fe}$, and $\mathrm{Mn}$ ) from ash by $0.05 \mathrm{M}$ $\mathrm{H}_{2} \mathrm{SO}_{4}$ at an $\mathrm{L} / \mathrm{S}$ ratio of $150 \mathrm{~mL} / \mathrm{g}$ for $4 \mathrm{~h}$. It was determined that elevated temperature was not suitable for $\mathrm{P}$ extraction as it caused high solubility of metals [117]. Semerci et al. also compared the impacts of extraction temperature $\left(23,30\right.$, and $\left.70{ }^{\circ} \mathrm{C}\right)$ and found that temperature was neither effective nor economical on P extraction [114]. Most other studies only investigated acidic extraction under room temperature $\left(20-25{ }^{\circ} \mathrm{C}\right)$ and atmospheric pressure. More comprehensive studies are necessary to determine the interactive effects between extraction temperature and other parameters, along with the cost-effectiveness.

Table 2 summarizes the percentage of extracted $P$ and leached heavy metals under various conditions from the literature. It is generally agreed that $\mathrm{HCl}, \mathrm{H}_{2} \mathrm{SO}_{4}, \mathrm{HNO}_{3}$, and oxalic acid result in a good $\mathrm{P}$ extraction for their strong acidity under identical extraction conditions (acid normality, L/S ratio, and contact time). However, the liquid $\mathrm{pH}$ during extraction is required to be maintained $\leq 2$ for a high extraction efficiency (up to 100\%) from sludge-derived ash and hydrochar. Exceptions apply to $\mathrm{H}_{2} \mathrm{SO}_{4}$, citric acid, and oxalic acid, which can still extract most $\mathrm{P}(>96 \%)$ at a slightly higher $\mathrm{pH}(2.1-2.6)$ under the extraction conditions of $20 \mathrm{~mL} / \mathrm{g}$ for $2 \mathrm{~h}$ [64]. $\mathrm{H}_{2} \mathrm{SO}_{4}$ and oxalic acid have the advantages of promoting the formation of poorly soluble $\mathrm{CaSO}_{4}$ and calcium oxalate, which improves the dissolution of Ca-P (see Eqs. (5) and (6)) $[31,118,119]$. It was also reported that citric acid could form metal complexes (e.g., $\mathrm{CaC}_{6} \mathrm{H}_{5} \mathrm{O}_{7}^{-}, \mathrm{FeC}_{6} \mathrm{H}_{5} \mathrm{O}_{7}, \mathrm{FeHC}_{6} \mathrm{H}_{5} \mathrm{O}_{7}$, and $\mathrm{FeC}_{6} \mathrm{H}_{5} \mathrm{O}_{7}^{-}$) and therefore improve the solubility of Ca-P and Fe-P and extracted P $[120,121]$. It should be noted that a much larger amount of 

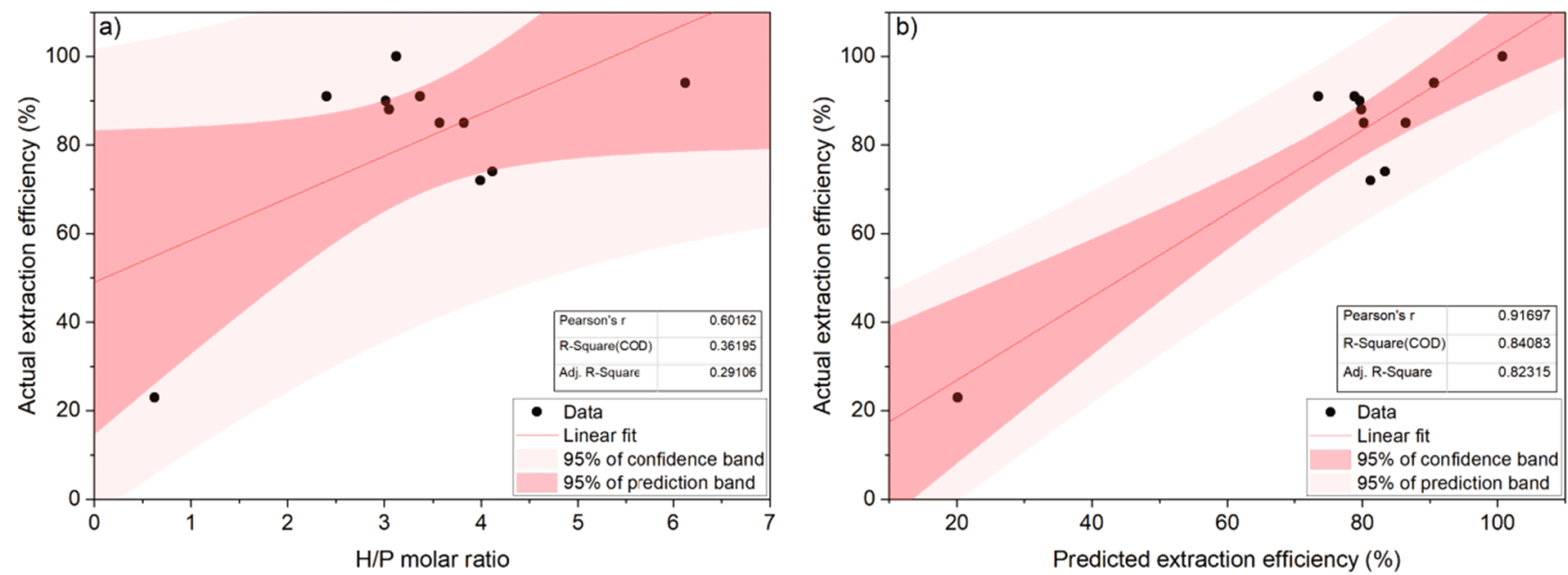

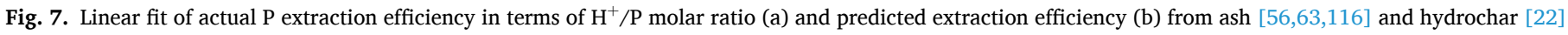

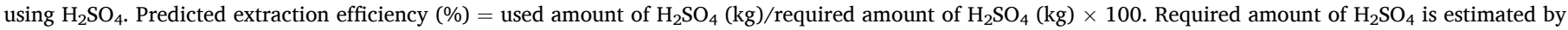
Eq. (7).

citric acid is required to achieve the low $\mathrm{pH}$ due to its weak strength $\left(\mathrm{K}_{\mathrm{a} 1}\right.$ $\left.=8.4 \times 10^{-3}\right)$ compared to oxalic acid $\left(\mathrm{K}_{\mathrm{a} 1}=5.9 \times 10^{-2}\right)$ and other strong acids. Regardless of other conditions, $\mathrm{P}$ extraction efficiency decreases with the increase of $\mathrm{pH}$ and remains minimum within the $\mathrm{pH}$ of 4-10 [52,64,67]. The Cracow University of Technology developed a patented method (PolFerAsh) of using a high concentration of $\mathrm{H}_{3} \mathrm{PO}_{4}$ $(2.7 \mathrm{M})$ to extract $\mathrm{P}$ from ash at an $\mathrm{L} / \mathrm{S}$ ratio of $4.3 \mathrm{~mL} / \mathrm{g}$ for $0.5 \mathrm{~h}$. The method was found to extract $62-92 \%$ of $P$ from most ashes generated by various treatment plants [48]. However, a negative P extraction efficiency $(-50 \%)$ was reported due to the high concentration of $\mathrm{Al}$ in ash and the caused precipitation of phosphate [48]. This does not mean that $\mathrm{H}_{3} \mathrm{PO}_{4}$ would result in a low extraction but reminds the consideration of material compositions when selecting extractants. A comparison study showed that at similar acid/ash mass ratios, using $\mathrm{H}_{3} \mathrm{PO}_{4}(0.49 \mathrm{~g} / \mathrm{g})$ and $\mathrm{HNO}_{3}(0.45 \mathrm{~g} / \mathrm{g})$ achieved similar $\mathrm{P}$ extraction efficiencies $(92 \%$ and $95 \%$, respectively) [122]. Using $\mathrm{H}_{3} \mathrm{PO}_{4}$ also provides a complement and high phosphate concentration of the extract to produce $P$ fertilizer with high purity. The use of acetic acid, formic acid, and gluconic acid only obtained low $\mathrm{P}$ extraction efficiencies in reported studies, probably due to the high $\mathrm{pH}$ (2.7-4.1) during extraction. Despite the variance among different acids, controlling $\mathrm{pH}$ of extraction (or post extracts) is more effective in assuring $P$ extraction efficiency.

Many studies have demonstrated that the extractant concentrations, $\mathrm{L} / \mathrm{S}$ ratios, and contact time can significantly affect the $\mathrm{P}$ extraction efficiency. Such influence is also correlated to the end $\mathrm{pH}$ of extraction solutions. It has been found that increasing extractant concentrations or $\mathrm{L} / \mathrm{S}$ ratios could enhance end $\mathrm{pH}$ and the $\mathrm{P}$ extraction efficiency up to a certain level (at equilibrium) while other variables are fixed [31]. Most studies used an $\mathrm{L} / \mathrm{S}$ ratio of $10 \mathrm{mg} / \mathrm{L}$ or higher for P extraction. However, considering the energy and capital costs, a low L/S ratio (as low as 2.3 $\mathrm{mL} / \mathrm{g}$ ) is preferred to achieve a concentrated $\mathrm{P}$ solution on the industrial scale [126]. Similarly, a low acid concentration (e.g., $0.01 \mathrm{~N}$ ) may also not be practical as it requires a significant amount of solution (e.g., $1,000 \mathrm{~mL} / \mathrm{g}$ ) to achieve a high P extraction efficiency but results in a low $\mathrm{P}$ concentration in the extract. Decreasing contact time also reduces end $\mathrm{pH}$, but it is the least influential factor compared to the other two and adequate extraction time should be allowed to obtain the maximum productivity [31]. Most studies have agreed that a contact time of $2 \mathrm{~h}$ is appropriate to reach the optimal $\mathrm{P}$ extraction from sludge-derived ash. Shorter extraction time (10 min) may be satisfactory on the industrial scale to obtain $>90 \%$ of extraction efficiency due to the intensive mixing process $(1,200 \mathrm{rpm})$ [61]. It should be noted that excessive contact time (e.g., 1 week) may be unfavorable due to $\mathrm{P}$ re-precipitation as well as the increase of leached heavy metals [83]. From the economic perspective, minimizing extraction time (solids residence time) and L/S ratio without reducing $\mathrm{P}$ extraction efficiency would be desirable for the bargain of equipment size and associated capital costs.

Limited studies have considered the influence of the abovementioned factors on $\mathrm{P}$ extraction from sludge-derived hydrochar. To date, only $\mathrm{H}_{2} \mathrm{SO}_{4}, \mathrm{HCl}$, citric acid, and oxalic acid have been used to extract $\mathrm{P}$ from hydrochar with satisfactory results, while few studies compared the differences among them [22,110]. Ovsyannikova et al. found that the effects of acid $\left(\mathrm{H}_{2} \mathrm{SO}_{4}\right)$ concentration on $\mathrm{P}$ extraction from hydrochar were similar to those from ash [22]. Acelas et al. found that a long extraction time (4-8 h) was required to reach a high $\mathrm{P}$ extraction efficiency (92-96\%) from hydrochar using $\mathrm{H}_{2} \mathrm{SO}_{4}$ and oxalic acid at $\mathrm{pH}$ $=2$ and $\mathrm{L} / \mathrm{S}=1,000 \mathrm{~mL} / \mathrm{g}$ [110]. Other studies reported that a 2 -h contact time obtained nearly $100 \%$ of extracted $\mathrm{P}$ with sufficient $\mathrm{H}_{2} \mathrm{SO}_{4}, \mathrm{HCl}$, and citric acid [22,127]. More studies are desired to comprehensively evaluate the impacts of processing variables on the $\mathrm{P}$ extraction from hydrochar, while current studies about ash can be used as guidance. Due to the complex compositions of ash and hydrochar derived from municipal sludge, it is important to optimize the extraction conditions for $\mathrm{P}$ recovery.

Concerning the optimization of extraction conditions for $\mathrm{P}$ recovery, response surface methodology (RSM) with second-order models has been widely used in the optimization of multi-parameter processes, which can efficiently optimize operational parameters with a minimum number of experimental runs [128]. The RSM using a central composite design consists of $2^{\mathrm{k}}(\mathrm{k}=$ number of independent variables) of factorial points (coded as \pm 1 ), $2 \mathrm{k}$ of axial points (coded as $\pm \alpha$ ), and 2-6 of center points (coded as 0) [53]. A quadratic poly-nominal model expressed by Eq. (8) can be performed to predict responses and examine the interactive relationships between the variables and the responses. Using RSM, Luyckx et al. optimized the cost-effective conditions for P extraction with only 16 runs for three variables (i.e., extractant concentration, $\mathrm{L} / \mathrm{S}$ ratio, and contact time) at three levels [31]. By coupling a multi-criteria techno-economic optimization, they also identified the optimal extractants $\left(\mathrm{H}_{2} \mathrm{SO}_{4}\right.$ and oxalic acid) for the lowest cost and lowest heavy metal co-extraction, respectively.

$Y=\beta_{0}+\sum_{i=1}^{3} \beta_{i} X_{i}+\sum_{i=1}^{3} \beta_{i i} X_{i}^{2}+\sum_{i=1}^{2} \sum_{j>i}^{3} \beta_{i j} X_{i} X_{j}$

where $Y$ is the response variable; $X_{i}$ and $X_{j}$ are the independent variables; $\beta_{0}, \beta_{i}, \beta_{i i}$ and $\beta_{i j}$ are the intercept, linear, quadratic, and interaction coefficients, respectively. 
Table 2

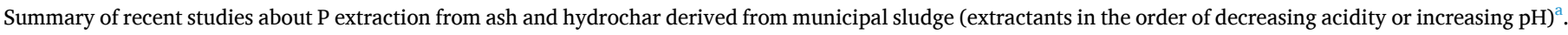

\begin{tabular}{|c|c|c|c|c|c|c|c|c|c|c|c|c|c|}
\hline \multirow[t]{2}{*}{ Extractants } & \multirow[t]{2}{*}{ Feedstock } & \multirow[t]{2}{*}{ Extraction conditions } & \multirow[t]{2}{*}{ Pre-pH } & \multirow[t]{2}{*}{ Post-pH } & PEE (\%) & Leac & d heavy & tals (\%) & & & & & Ref. \\
\hline & & & & & & As & $\mathrm{Cd}$ & $\mathrm{Cr}$ & $\mathrm{Cu}$ & $\mathrm{Ni}$ & $\mathrm{Pb}$ & $\mathrm{Zn}$ & \\
\hline $\mathrm{HCl}$ & Ash & $0.1 \mathrm{~N}, 10 \mathrm{~mL} / \mathrm{g}, 2 \mathrm{~h}$ & 1.1 & 3.1 & 16 & - & 11 & 0.5 & 15 & 8 & ND & 16 & {$[31]$} \\
\hline & & $0.5 \mathrm{~N}, 10 \mathrm{~mL} / \mathrm{g}, 2 \mathrm{~h}$ & 0.4 & 1.5 & 91 & - & 29 & 5 & 41 & 11 & 35 & 33 & \\
\hline & & $0.8 \mathrm{~N}, 10 \mathrm{~mL} / \mathrm{g}, 0.16 \mathrm{~h}$ & - & 2 & 88 & - & - & - & - & - & - & - & {$[51]$} \\
\hline & & $5.2 \mathrm{~N}, 3 \mathrm{~mL} / \mathrm{g}, 0.16 \mathrm{~h}$ & - & -1.22 & 72 & - & - & - & - & - & - & - & [82] \\
\hline & & $3.9 \mathrm{~N}, 2.5 \mathrm{~mL} / \mathrm{g}, 0.16 \mathrm{~h}$ & - & -0.63 & 73 & - & - & - & - & - & - & - & \\
\hline & & $0.5 \mathrm{~N}, 25 \mathrm{~mL} / \mathrm{g}, 2 \mathrm{~h}$ & - & - & 80 & - & - & - & - & - & - & - & [123] \\
\hline & & $0.8 \mathrm{~N}, 25 \mathrm{~mL} / \mathrm{g}, 2 \mathrm{~h}$ & - & - & 83 & - & - & - & - & - & - & - & \\
\hline & & $0.4 \mathrm{~N}, 10 \mathrm{~mL} / \mathrm{g}, 24 \mathrm{~h}$ & - & 3.22 & 0.7 & - & 65 & 0.5 & 42 & 16 & 0.7 & 26 & [106] \\
\hline & & $0.4 \mathrm{~N}, 75 \mathrm{~mL} / \mathrm{g}, 2 \mathrm{~h}$ & - & - & 95 & - & - & - & - & - & - & - & [114] \\
\hline & & $0.2 \mathrm{~N}, 50 \mathrm{~mL} / \mathrm{g}, 2 \mathrm{~h}$ & - & - & $87-98$ & - & - & $4-24$ & $60-63$ & $0-63$ & $42-57$ & $15-86$ & {$[55]$} \\
\hline & Hydrochar & $1 \mathrm{~N}, 10 \mathrm{~mL} / \mathrm{g}, 2 \mathrm{~h}$ & - & - & 98 & - & - & - & - & - & - & - & {$[22]$} \\
\hline $\mathrm{H}_{2} \mathrm{SO}_{4}$ & Ash & $0.1 \mathrm{~N}, 10 \mathrm{~mL} / \mathrm{g}, 2 \mathrm{~h}$ & 1.2 & 3.1 & 16 & - & 12 & 0.5 & 16 & 8 & ND & 17 & {$[31]$} \\
\hline & & $0.5 \mathrm{~N}, 10 \mathrm{~mL} / \mathrm{g}, 2 \mathrm{~h}$ & 0.6 & 1.8 & 90 & - & 30 & 5 & 42 & 11 & 3 & 36 & \\
\hline & & $0.2 \mathrm{~N}, 20 \mathrm{~mL} / \mathrm{g}, 2 \mathrm{~h}$ & 1.3 & 3.2 & 19 & 53 & - & - & 35 & 6 & 1 & 27 & [64] \\
\hline & & $0.4 \mathrm{~N}, 20 \mathrm{~mL} / \mathrm{g}, 2 \mathrm{~h}$ & 1.26 & 2.1 & 100 & 100 & - & - & 43 & 7 & 10 & 32 & \\
\hline & & $1.0 \mathrm{~N}, 20 \mathrm{~mL} / \mathrm{g}, 2 \mathrm{~h}$ & 0.9 & 1.1 & 107 & 100 & - & - & 43 & 9 & 15 & 32 & \\
\hline & & $0.38 \mathrm{~N}, 20 \mathrm{~mL} / \mathrm{g}, 2 \mathrm{~h}$ & - & - & $72-91$ & - & - & - & - & - & - & $0-56$ & [63] \\
\hline & & $0.5 \mathrm{~N}, 30 \mathrm{~mL} / \mathrm{g}, 2 \mathrm{~h}$ & - & - & 82 & - & - & - & - & - & - & - & {$[62]$} \\
\hline & & $0.3 \mathrm{~N}, 50 \mathrm{~mL} / \mathrm{g}, 2 \mathrm{~h}$ & - & - & $65-85$ & - & - & - & - & - & - & - & [124] \\
\hline & & $0.4 \mathrm{~N}, 20 \mathrm{~mL} / \mathrm{g}, 2 \mathrm{~h}$ & - & - & 94 & 10 & - & 1 & 36 & 15 & 10 & 33 & [116] \\
\hline & & $0.38 \mathrm{~N}, 20 \mathrm{~mL} / \mathrm{g}, 2 \mathrm{~h}$ & - & - & 100 & - & - & - & 78 & - & - & - & [83] \\
\hline & & $0.38 \mathrm{~N}, 20 \mathrm{~mL} / \mathrm{g}, 2 \mathrm{~h}$ & - & - & 99 & - & - & - & 60 & - & - & - & \\
\hline & & $0.2 \mathrm{~N}, 20 \mathrm{~mL} / \mathrm{g}, 2 \mathrm{~h}$ & - & - & 88 & - & - & - & 12 & - & - & 7 & [125] \\
\hline & & $0.6 \mathrm{~N}, 20 \mathrm{~mL} / \mathrm{g}, 0.5 \mathrm{~h}$ & - & - & $89-90$ & - & - & - & $60-66$ & & & $31-50$ & {$[66]$} \\
\hline & Hydrochar & $1,000 \mathrm{~mL} / \mathrm{g}, 8 \mathrm{~h}$ & - & 2 & $80-92$ & - & - & - & - & - & - & - & [110] \\
\hline & & $0.2 \mathrm{~N}, 10 \mathrm{~mL} / \mathrm{g}, 2 \mathrm{~h}$ & - & - & 23 & - & - & - & - & - & - & - & {$[22]$} \\
\hline & & $1 \mathrm{~N}, 10 \mathrm{~mL} / \mathrm{g}, 2 \mathrm{~h}$ & - & - & 100 & - & - & - & - & - & - & - & \\
\hline $\mathrm{HNO}_{3}$ & Ash & $0.1 \mathrm{~N}, 10 \mathrm{~mL} / \mathrm{g}, 2 \mathrm{~h}$ & 1.0 & 2.9 & 17 & - & 11 & 0.5 & 15 & 7 & ND & 17 & {$[31]$} \\
\hline & & $0.5 \mathrm{~N}, 10 \mathrm{~mL} / \mathrm{g}, 2 \mathrm{~h}$ & 0.3 & 1.4 & 88 & - & 27 & 4.5 & 37 & 10 & 21 & 33 & \\
\hline & & $0.1 \mathrm{~N}, 20 \mathrm{~mL} / \mathrm{g}, 2 \mathrm{~h}$ & 1.2 & 3.4 & 3 & 20 & - & - & 20 & 4 & 1 & 23 & [64] \\
\hline & & $0.2 \mathrm{~N}, 20 \mathrm{~mL} / \mathrm{g}, 2 \mathrm{~h}$ & 0.88 & 2.2 & 83 & 28 & - & - & 40 & 6 & 18 & 14 & \\
\hline & & $0.5 \mathrm{~N}, 20 \mathrm{~mL} / \mathrm{g}, 2 \mathrm{~h}$ & 0.85 & 1.0 & 101 & 43 & - & - & 42 & 7 & 49 & 32 & \\
\hline & & $2.7 \mathrm{~N}, 2.3-3.7 \mathrm{~mL} / \mathrm{g}, 2 \mathrm{~h}$ & - & $0.13-1.1$ & $80-96$ & - & - & - & - & - & - & - & [126] \\
\hline $\mathrm{H}_{3} \mathrm{PO}_{4}$ & Ash & $8.1 \mathrm{~N}, 4.3 \mathrm{~mL} / \mathrm{g}, 0.5 \mathrm{~h}$ & - & - & $-50-92$ & - & $54-71$ & $22-37$ & $37-68$ & $19-45$ & - & - & [48] \\
\hline Oxalic acid & Ash & $0.1 \mathrm{~N}, 10 \mathrm{~mL} / \mathrm{g}, 2 \mathrm{~h}$ & 1.5 & 4.1 & 18 & - & 1 & 0.5 & 17 & 6 & ND & 14 & {$[31]$} \\
\hline & & $0.5 \mathrm{~N}, 10 \mathrm{~mL} / \mathrm{g}, 2 \mathrm{~h}$ & 1.0 & 2.2 & 95 & - & 6 & 6 & 35 & 9 & ND & 33 & \\
\hline & & $0.2 \mathrm{~N}, 20 \mathrm{~mL} / \mathrm{g}, 2 \mathrm{~h}$ & 1.5 & 4.6 & 32 & 88 & - & - & 33 & 5 & 12 & 23 & [64] \\
\hline & & $0.4 \mathrm{~N}, 20 \mathrm{~mL} / \mathrm{g}, 2 \mathrm{~h}$ & 1.3 & 2.4 & 96 & 91 & - & - & 35 & 6 & 21 & 23 & \\
\hline & & $1.0 \mathrm{~N}, 20 \mathrm{~mL} / \mathrm{g}, 2 \mathrm{~h}$ & 1.2 & 1.2 & 104 & 93 & - & - & 37 & 6 & 39 & 24 & \\
\hline & & $0.5 \mathrm{~N}, 30 \mathrm{~mL} / \mathrm{g}, 2 \mathrm{~h}$ & - & - & 93 & - & - & - & - & - & - & - & {$[62]$} \\
\hline & & $0.34 \mathrm{~N}, 50 \mathrm{~mL} / \mathrm{g}, 2 \mathrm{~h}$ & - & - & $92-98$ & - & - & - & - & - & - & - & [124] \\
\hline & Hydrochar & $1,000 \mathrm{~mL} / \mathrm{g}, 8 \mathrm{~h}$ & - & 2 & $84-95$ & - & - & - & - & - & - & - & [110] \\
\hline Citric acid & Ash & $0.1 \mathrm{~N}, 10 \mathrm{~mL} / \mathrm{g}, 2 \mathrm{~h}$ & 2.3 & 3.9 & 13 & - & 8 & 0.5 & 13 & 7 & 1 & 15 & [31] \\
\hline & & $0.5 \mathrm{~N}, 10 \mathrm{~mL} / \mathrm{g}, 2 \mathrm{~h}$ & 1.9 & 2.7 & 21 & - & 12 & 1 & 17 & 8 & 1 & 20 & \\
\hline & & $0.3 \mathrm{~N}, 20 \mathrm{~mL} / \mathrm{g}, 2 \mathrm{~h}$ & 2.0 & 3.6 & 52 & 74 & - & - & 30 & 4 & 1 & 18 & [64] \\
\hline & & $0.6 \mathrm{~N}, 20 \mathrm{~mL} / \mathrm{g}, 2 \mathrm{~h}$ & 1.8 & 3.1 & 75 & 99 & - & - & 43 & 9 & 4 & 32 & \\
\hline & & $1.5 \mathrm{~N}, 20 \mathrm{~mL} / \mathrm{g}, 2 \mathrm{~h}$ & 1.7 & 2.6 & 105 & 100 & - & - & 73 & 56 & 12 & 73 & \\
\hline & Hydrochar & $10 \mathrm{~mL} / \mathrm{g}, 2 \mathrm{~h}$ & - & 2 & 59-95 & - & - & - & - & - & - & - & [127] \\
\hline & & $1 \mathrm{~N}, 10 \mathrm{~mL} / \mathrm{g}, 2 \mathrm{~h}$ & - & - & 60 & - & - & - & - & - & - & - & {$[22]$} \\
\hline Gluconic acid & Ash & $0.1 \mathrm{~N}, 10 \mathrm{~mL} / \mathrm{g}, 2 \mathrm{~h}$ & 2.4 & 4.0 & 10 & - & 7 & 0.5 & 12 & 6 & 6 & 13 & [31] \\
\hline & & $0.5 \mathrm{~N}, 10 \mathrm{~mL} / \mathrm{g}, 2 \mathrm{~h}$ & 2.0 & 2.9 & 21 & - & 11 & 1 & 17 & 7 & 13 & 21 & \\
\hline Formic acid & Ash & $0.1 \mathrm{~N}, 10 \mathrm{~mL} / \mathrm{g}, 2 \mathrm{~h}$ & 2.4 & 3.5 & 17 & - & 7 & ND & 10 & 7 & ND & 12 & [31] \\
\hline & & $0.5 \mathrm{~N}, 10 \mathrm{~mL} / \mathrm{g}, 2 \mathrm{~h}$ & 1.9 & 2.7 & 11 & - & 9 & ND & 14 & 8 & ND & 16 & \\
\hline Acetic acid & Ash & $0.1 \mathrm{~N}, 10 \mathrm{~mL} / \mathrm{g}, 2 \mathrm{~h}$ & 2.9 & 4.1 & 5 & - & 3 & ND & 5 & 3 & ND & 4 & {$[31]$} \\
\hline & & $0.5 \mathrm{~N}, 10 \mathrm{~mL} / \mathrm{g}, 2 \mathrm{~h}$ & 2.5 & 3.6 & 9 & - & 7 & ND & 10 & 7 & ND & 11 & \\
\hline EDTMP & Ash & $0.04 \mathrm{~N}, 20 \mathrm{~mL} / \mathrm{g}, 2 \mathrm{~h}$ & 2.1 & 4.1 & 19 & 51 & - & - & 10 & 1 & 14 & 11 & [64] \\
\hline & & $0.08 \mathrm{~N}, 20 \mathrm{~mL} / \mathrm{g}, 2 \mathrm{~h}$ & 1.9 & 3.5 & 20 & 77 & - & - & 14 & 3 & 23 & 18 & \\
\hline & & $0.2 \mathrm{~N}, 20 \mathrm{~mL} / \mathrm{g}, 2 \mathrm{~h}$ & 1.7 & 2.6 & 26 & 95 & - & - & 22 & 5 & 33 & 23 & \\
\hline & & $0.2 \mathrm{~N}, 10 \mathrm{~mL} / \mathrm{g}, 2 \mathrm{~h}$ & 1.3 & 2.5 & 15 & - & - & - & 10 & - & - & 10 & [107] \\
\hline EDTA & Ash & $0.04 \mathrm{~N}, 20 \mathrm{~mL} / \mathrm{g}, 2 \mathrm{~h}$ & 4.8 & 6.5 & 9 & 70 & - & - & 7 & 3 & 14 & 14 & [64] \\
\hline & & $0.08 \mathrm{~N}, 20 \mathrm{~mL} / \mathrm{g}, 2 \mathrm{~h}$ & 4.7 & 6.2 & 18 & 86 & - & - & 12 & 4 & 19 & 17 & \\
\hline & & $0.2 \mathrm{~N}, 20 \mathrm{~mL} / \mathrm{g}, 2 \mathrm{~h}$ & 4.7 & 5.5 & 37 & 81 & - & - & 20 & 5 & 24 & 18 & \\
\hline & & $0.2 \mathrm{~N}, 10 \mathrm{~mL} / \mathrm{g}, 2 \mathrm{~h}$ & 4.7 & 5.5 & 25 & - & - & - & 5 & - & - & 15 & [107] \\
\hline $\mathrm{Na}_{2}$-EDTA & Ash & $0.1 \mathrm{~N}, 10 \mathrm{~mL} / \mathrm{g}, 2 \mathrm{~h}$ & 4.5 & 5.4 & 8 & - & 6 & ND & 12 & 5 & 13 & 11 & [31] \\
\hline & & $0.5 \mathrm{~N}, 10 \mathrm{~mL} / \mathrm{g}, 2 \mathrm{~h}$ & 4.5 & 5.0 & 12 & - & 8 & ND & 14 & 7 & 17 & 16 & \\
\hline $\mathrm{Na}_{2}$-oxalate & Ash & $0.1 \mathrm{~N}, 10 \mathrm{~mL} / \mathrm{g}, 2 \mathrm{~h}$ & 8.6 & 8.5 & 1 & - & ND & ND & 5 & ND & ND & 1 & \\
\hline & & $0.5 \mathrm{~N}, 10 \mathrm{~mL} / \mathrm{g}, 2 \mathrm{~h}$ & 10.2 & 9.1 & 2 & - & ND & ND & 5 & ND & ND & 1 & \\
\hline $\mathrm{Na}_{4}$-EDTA & Ash & $0.1 \mathrm{~N}, 10 \mathrm{~mL} / \mathrm{g}, 2 \mathrm{~h}$ & 10.4 & 9.8 & 6 & - & ND & ND & 8 & ND & 10 & 4 & \\
\hline & & $0.5 \mathrm{~N}, 10 \mathrm{~mL} / \mathrm{g}, 2 \mathrm{~h}$ & 9.9 & 10.1 & 14 & - & 3 & ND & 9 & ND & 10 & 5 & \\
\hline $\mathrm{EDTA}+\mathrm{NaOH}$ & Ash & $0.1 \mathrm{~N}, 10 \mathrm{~mL} / \mathrm{g}, 2 \mathrm{~h}$ & 10.9 & 10.0 & 6 & - & ND & ND & 8 & ND & 0.5 & 4 & \\
\hline & & $0.5 \mathrm{~N}, 10 \mathrm{~mL} / \mathrm{g}, 2 \mathrm{~h}$ & 10.7 & 10.4 & 13 & - & ND & ND & 8 & ND & 0.5 & 5 & \\
\hline $\mathrm{NTA}+\mathrm{NaOH}$ & Ash & $0.1 \mathrm{~N}, 10 \mathrm{~mL} / \mathrm{g}, 2 \mathrm{~h}$ & 10.9 & 10.2 & 3 & - & ND & 0.5 & 7 & ND & 7 & 3 & \\
\hline & & $0.5 \mathrm{~N}, 10 \mathrm{~mL} / \mathrm{g}, 2 \mathrm{~h}$ & 10.8 & 9.9 & 5 & - & ND & 0.1 & 7 & ND & 8 & 4 & \\
\hline
\end{tabular}


Table 2 (continued)

\begin{tabular}{|c|c|c|c|c|c|c|c|c|c|c|c|c|c|}
\hline \multirow[t]{2}{*}{ Extractants } & \multirow[t]{2}{*}{ Feedstock } & \multirow[t]{2}{*}{ Extraction conditions } & \multirow[t]{2}{*}{ Pre-pH } & \multirow[t]{2}{*}{ Post-pH } & \multirow[t]{2}{*}{ PEE (\%) } & \multicolumn{7}{|c|}{ Leached heavy metals (\%) } & \multirow[t]{2}{*}{ Ref. } \\
\hline & & & & & & As & $\mathrm{Cd}$ & $\mathrm{Cr}$ & $\mathrm{Cu}$ & $\mathrm{Ni}$ & $\mathrm{Pb}$ & $\mathrm{Zn}$ & \\
\hline \multirow[t]{2}{*}{$\mathrm{KOH}$} & \multirow[t]{2}{*}{ Hydrochar } & \multirow[t]{2}{*}{$100 \mathrm{~mL} / \mathrm{g}, 16 \mathrm{~h}$} & - & 11 & 32 & - & - & - & - & - & - & - & \multirow[t]{2}{*}{ [97] } \\
\hline & & & - & 12 & $90-96$ & - & - & - & - & - & - & - & \\
\hline \multirow[t]{9}{*}{$\mathrm{NaOH}$} & \multirow[t]{7}{*}{ Ash } & $0.1 \mathrm{~N}, 10 \mathrm{~mL} / \mathrm{g}, 2 \mathrm{~h}$ & 12.6 & 12.5 & 1 & - & ND & ND & ND & ND & 0.5 & 0.5 & \multirow[t]{2}{*}{ [31] } \\
\hline & & $0.5 \mathrm{~N}, 10 \mathrm{~mL} / \mathrm{g}, 2 \mathrm{~h}$ & 13.0 & 12.7 & 34 & - & ND & ND & 0.1 & ND & ND & 1 & \\
\hline & & $0.5 \mathrm{~N}, 25 \mathrm{~mL} / \mathrm{g}, 2 \mathrm{~h}$ & - & - & 18 & - & - & - & - & - & - & - & \multirow[t]{2}{*}{ [123] } \\
\hline & & $0.8 \mathrm{~N}, 25 \mathrm{~mL} / \mathrm{g}, 2 \mathrm{~h}$ & - & - & 25 & - & - & - & - & - & - & - & \\
\hline & & $0.2 \mathrm{~N}, 10 \mathrm{~mL} / \mathrm{g}, 1 \mathrm{~h}$ & - & - & 49 & - & - & - & - & - & - & - & {$[51]$} \\
\hline & & $1 \mathrm{~N}, 75 \mathrm{~mL} / \mathrm{g}, 2 \mathrm{~h}$ & - & - & 60 & - & - & - & - & - & - & - & [114] \\
\hline & & $0.8 \mathrm{~N}, 50 \mathrm{~mL} / \mathrm{g}, 2 \mathrm{~h}$ & - & - & $25-26$ & - & - & - & - & - & - & - & {$[55]$} \\
\hline & \multirow[t]{2}{*}{ Hydrochar } & $1 \mathrm{~N}, 10 \mathrm{~mL} / \mathrm{g}, 2 \mathrm{~h}$ & - & - & 2 & - & - & - & - & - & - & - & {$[22]$} \\
\hline & & $1 \mathrm{~N}, 100 \mathrm{~mL} / \mathrm{g}, 2 \mathrm{~h}$ & - & - & $25-56$ & - & - & - & - & - & - & - & {$[35]$} \\
\hline
\end{tabular}

\footnotetext{
${ }^{a}$ Extraction conditions include extractant concentration ( $\left.\mathrm{N}\right)$, liquid to solid ratio (mL/g), and contact time (h). Pre-pH = pH of extractant before extraction; Post-pH

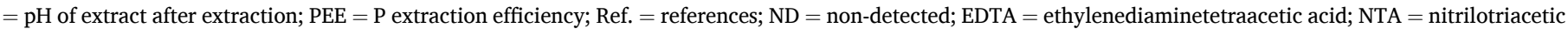
acid; EDTMP = ethylene diamine tetramethylene phosphonate; "_" donates "not available".
}

\subsubsection{Concerns of heavy metals}

Along with $\mathrm{P}$, dissolution of heavy metals is inevitable during acidic extraction, while the dissolved amount depends on the compositions of ash and hydrochar, as well as acid types. As shown in Table 2, higher $\mathrm{P}$ extraction efficiency is generally associated with more leachable heavy metals because of more free acids. Particularly, both inorganic and organic acids have been found effective in leaching $\mathrm{As}, \mathrm{Cu}$, and $\mathrm{Zn}$ from sludge-derived ash. Besides, Cd can be effectively extracted by inorganic acids. One study suggested that organic acids leached more heavy metals from ash (especially $\mathrm{As}, \mathrm{Cu}, \mathrm{Pb}$, and $\mathrm{Zn}$ ) than inorganic acids [64]. $\mathrm{HCl}$ was found to be an effective leaching agent for all tested metals (e.g., As, $\mathrm{Cd}, \mathrm{Cr}, \mathrm{Cu}, \mathrm{Ni}, \mathrm{Pb}$, and $\mathrm{Zn}$ ) [55]. $\mathrm{H}_{3} \mathrm{PO}_{4}$ and citric acid were found to be efficient in extracting $\mathrm{Ni}[48,64]$. Over $39 \%$ of $\mathrm{Pb}$ was also extracted by $\mathrm{HNO}_{3}$ and oxalic acid along with most extracted $\mathrm{P}$ [64]. However, there is a lack of study showing the leachable heavy metals from sludgederived hydrochar. One study showed that citric acid $(\mathrm{pH}=2)$ could achieve high $\mathrm{P}$ extraction efficiency from hydrochar but cause limited heavy metals in recovered struvite due to formed citrate complexes; however, the reagent cost may be too high [127]. It was reported that dosing citric acid (at a stoichiometric ratio $\mathrm{C}_{6} \mathrm{H}_{8} \mathrm{O}_{7}: \Sigma(\mathrm{Fe}, \mathrm{Al}, \mathrm{Ca}, \mathrm{Mg})=$ $\sim 1$ ) to acidic leachate could form metal complexes staying in solution during struvite precipitation [129]. Through a multi-criteria technoeconomic analysis, Luyckx et al. found that $\mathrm{H}_{2} \mathrm{SO}_{4}(0.5 \mathrm{~N}, 10 \mathrm{~mL} / \mathrm{g}, 2 \mathrm{~h})$ and oxalic acid $(0.5 \mathrm{~N}, 12.8 \mathrm{~mL} / \mathrm{g}, 2 \mathrm{~h})$ showed the best trade-off among high extraction efficiency of $\mathrm{P}(>80 \%)$, low leached amount of heavy metal and desirable operational costs [31]. Considering the high efficiency of low-cost $\mathrm{H}_{2} \mathrm{SO}_{4}$ and the complexing effects of citrate acid, combining two acids might be an approach to find a balance among $\mathrm{P}$ extraction, costs, and concerning heavy metals.

As a result of leached heavy metals by acidic extraction, additional chemicals and/or energy inputs are necessary to separate P from heavy metals and ensure the quality of recovered products. Several separation techniques have been attempted, including cationic ion exchange, liquid-liquid extraction (PASCH process), nanofiltration, sequential precipitation, and sulfidic precipitation [52]. Nevertheless, none of them have been demonstrated to be applicable to a large scale due to their complexity and economic infeasibility [52,106]. Further efforts are needed to optimize the removal of metals from acidic extracts, such as developing cheap and regenerable resins for ion exchange and finding cost-effective adsorbents.

\subsubsection{Pretreatment with chelating agents}

Chelating agents have been examined for the leachability of heavy metals from sludge-derived ash for the purpose of pretreatment (heavy metal removal) prior to $\mathrm{P}$ extraction. The pretreatment involves prewashing ash to remove heavy metals but retain $\mathrm{P}$ in the prewashed ash, which will be extracted with acids for P recovery. The studied chelating agents include ethylene diamine tetramethylene phosphonate (EDTMP), ethylenediaminetetraacetic acid (EDTA), nitrilotriacetic acid (NTA), $\mathrm{Na}_{2}$-EDTA, $\mathrm{Na}_{2}$-oxalate, and $\mathrm{Na}_{4}$-EDTA $[31,64,107,116]$. As shown in Table 2, EDTMP and EDTA could leach a considerable amount of P (9-37\%) but with limited removal of most heavy metals/metalloids ( $\leq 33 \%)$ except for As $(\geq 51 \%) . \mathrm{Na}_{2}$-EDTA, $\mathrm{Na}_{2}$-oxalate, $\mathrm{Na}_{4}$-EDTA, and NTA-NaOH showed limited leachability for both P (1-14\%) and heavy metals $(\leq 17 \%)$. It is also reported that increased $P$ leaching and decreased heavy metal removal by chelating agents are due to the decreased $\mathrm{pH}$ of extracts after extraction. In terms of minimizing P loss $(<15 \%$ of total P) and maximizing heavy metal removal ( $>25 \%$ of total metals), none of the above-mentioned chelating agents has been considered appropriate as the lost $\mathrm{P}$ outweighs the insufficient removal of heavy metals.

\subsection{Alkalic extraction}

Direct alkaline extraction is a promising alternative to avoid the codissolution of heavy metals, but it requires strong bases, e.g., $\mathrm{NaOH}$ and $\mathrm{KOH}$. As expected, alkaline extractants (e.g., $\mathrm{NaOH}$ ) could hardly leach heavy metals $(<1 \%)$ due to high $\mathrm{pH}$ (Table 2$)$. Under alkalic conditions $(\mathrm{pH} \geq 12)$, only NAIP can be extracted while heavy metals remain in sludge-derived ash and hydrochar (Eqs. (9)-(11)) [130,131]. Consequently, this process is highly selective on the compositions of ash and hydrochar.

$\mathrm{AlPO}_{4}+4 \mathrm{OH}^{-} \rightleftharpoons\left[\mathrm{Al}(\mathrm{OH})_{4}\right]^{-}+\mathrm{PO}_{4}{ }^{3-}$

$\mathrm{Fe}_{3}\left(\mathrm{PO}_{4}\right)_{2}+6 \mathrm{OH}^{-} \rightleftharpoons 3 \mathrm{Fe}(\mathrm{OH})_{2} \downarrow+2 \mathrm{PO}_{4}{ }^{3-}$

$\mathrm{FePO}_{4}+3 \mathrm{OH}^{-} \rightleftharpoons \mathrm{Fe}(\mathrm{OH})_{3} \downarrow+\mathrm{PO}_{4}{ }^{3-}$

Particularly, it is found that the $\mathrm{P}$ recovery rate is greatly dependent on the $\mathrm{P} / \mathrm{Ca}$ molar ratio. Fig. 8 shows that $\mathrm{P}$ extraction efficiency reduces significantly with the decrease of $\mathrm{P} / \mathrm{Ca}$ molar ratio in ash and hydrochar. It was also reported that alkalic extraction of $\mathrm{P}$ became infeasible when the $\mathrm{CaO}$ concentration in ash exceeded 20\% [132]. Therefore, Ca-rich ash or hydrochar would not be suitable for P extraction using alkaline leaching.

Similar to acidic leaching, P extraction efficiency of alkalic extraction improves with the increase of extractant concentrations (or higher extraction $\mathrm{pH}$ ), $\mathrm{L} / \mathrm{S}$ ratios, and contact time within certain ranges. $\mathrm{Xu}$ et al. found that $\mathrm{P}$ extraction efficiency enhanced from $1 \%$ to $25 \%$ of total $\mathrm{P}$ in ash when $\mathrm{NaOH}$ concentrations increased from $0.01 \mathrm{M}$ to $0.8 \mathrm{M}$ $(\mathrm{L} / \mathrm{S}=25 \mathrm{~mL} / \mathrm{g}, 2 \mathrm{~h}$ ), while it only improved $5 \%$ when $\mathrm{L} / \mathrm{S}$ increased from 25 to $200 \mathrm{~mL} / \mathrm{g}(0.01 \mathrm{~N}, 2 \mathrm{~h})$ [123]. It was suggested that limited P could be extracted from hydrochar at low $\mathrm{pH}$ (e.g., $<10 \%$ at $\mathrm{pH}=10.5$ ), while the extraction efficiency did not increase significantly at $\mathrm{pH}>12$ ( $\mathrm{L} / \mathrm{S}=100 \mathrm{~mL} / \mathrm{g}, 16 \mathrm{~h}$ ) [97]. Sufficient contact time should be allowed to achieve maximum extraction efficiency. Luyckx et al. reported that 


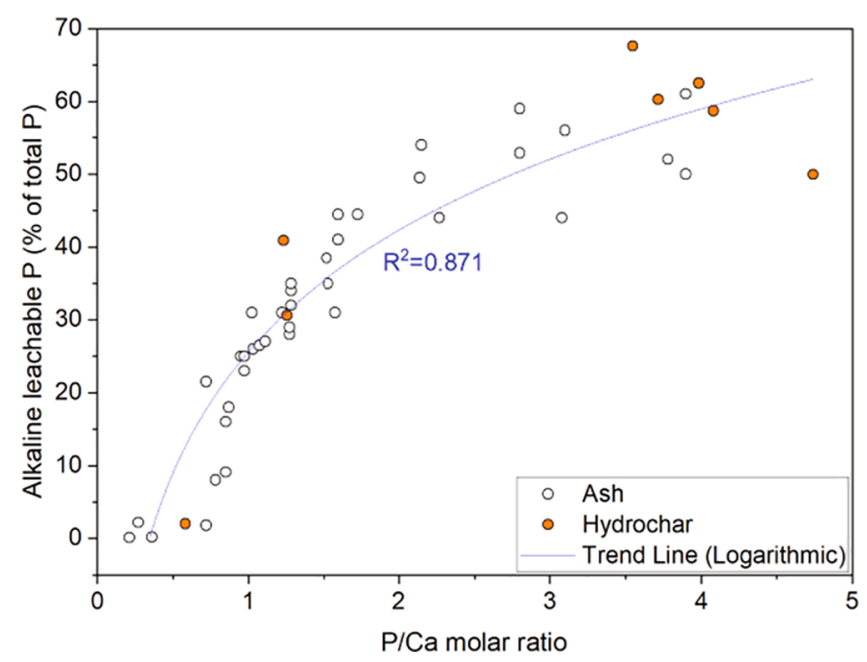

Fig. 8. Alkaline-extractable $\mathrm{P}$ versus the corresponding $\mathrm{P} / \mathrm{Ca}$ molar ratio in sludge-derived ash and hydrochar. Data sourced from [15,22,35,52].

the leached P from ash increased from $9 \%$ to $42 \%$ with increasing contact time (10 to $120 \mathrm{~min}$ ) with $0.5 \mathrm{~N} \mathrm{NaOH}$ at L/S $=50 \mathrm{~mL} / \mathrm{g}$ [31]. Through a kinetics study, Li et al. observed that the $\mathrm{P}$ extraction equilibrium can be reached within approximately $1-4 \mathrm{~h}$ depending on the compositions of hydrochar. The P desorption results were found to fit Pseudo-second-order (Eq. (12)) better than Pseudo-first-order (Eq. (13)) [97]. It indicates that the $P$ desorption process is primarily controlled by chemisorption rather than diffusion, and the reaction rate is limited over time with the concentration of one or more substances [133].

$q_{t}=q_{e}\left(1-e^{-k_{1} t}\right)$

$q_{t}=\frac{q_{e}^{2} k_{2} t}{1+q_{e} k_{2} t}$

The above equations can be converted as linear forms (Eqs. (14) and (15)) to assist the calculation of model parameters:

$\ln \left(q_{e}-q_{t}\right)=\ln \left(q_{e}\right)-k_{1} t$

$\frac{t}{q_{t}}=\frac{1}{k_{2} q_{e}{ }^{2}}+\frac{1}{q_{e}} t$

where $q_{t}$ : Extraction capacity at time $\mathrm{t}(\mathrm{min}), \mathrm{mg} / \mathrm{g} ; q_{e}$ : Extraction capacity at equilibrium, $\mathrm{mg} / \mathrm{g} ; k_{1}$ : Pseudo-first-order rate constant, $\mathrm{min}^{-1}$; and, $k_{2}$ : Pseudo-second-order rate constant, $\mathrm{g} /(\mathrm{mg} \min )$.

The upstream treatment conditions can also affect the P extraction efficiency due to the transformation of $\mathrm{P}$ species (see Section 3.2). Higher incineration or hydrothermal temperatures generally reduces the relative percentages of NAIP and increases AP contents in sludgederived ash or hydrochar, thus reducing the extractable $\mathrm{P}$ by alkalic method [35]. Another study reached a very high extraction efficiency $\left(>89 \%\right.$ of total P) from hydrochar $\left(200{ }^{\circ} \mathrm{C}\right.$ for $4 \mathrm{~h}$ ) using $\mathrm{KOH}$ solution $(\mathrm{pH} \geq 12)$, as the sludge was produced from chemical $\mathrm{P}$ removal process with poly-aluminum sulfate during wastewater treatment. It was also suggested that adding $\mathrm{FeCl}_{3}$ could promote the selective transformation of AP to NAIP under hydrothermal conditions and enhance alkalicextractable P [97]. Many studies found that extracted P $(<60 \%$ of total $\mathrm{P}$ ) was limited from sludge-derived ash and hydrochar using alkalic method (Table 2), restricting the wide application of this approach.

A successful full-scale application of alkalic extraction technique in Gifu City, Japan, has been operating since 2010, with a reported P leaching rate of up to $75 \%$ of total $\mathrm{P}[52,132,134]$. Briefly, P-rich leachate is extracted with $1 \mathrm{~N} \mathrm{NaOH}$ at $50-70{ }^{\circ} \mathrm{C}$ for $1.5 \mathrm{~h}$ from locally produced ash from sewage sludge, and $\mathrm{P}$ is recovered as hydroxyapatite by subsequent precipitation using $\mathrm{Ca}(\mathrm{OH})_{2}$ at $20-50{ }^{\circ} \mathrm{C}$ for $9 \mathrm{~h}$. The remaining alkaline solution is recycled for $\mathrm{P}$ extraction to save chemical costs. The solid residue from extraction is washed by $\mathrm{H}_{2} \mathrm{SO}_{4}$ solution $(\mathrm{pH}=4.5-5.5)$ to remove hazardous metals and can be safely reused as construction materials. However, further reduction of the cost of chemicals is necessary and critical to make this process more economically practicable $[132,134]$.

\subsection{Sequential extraction}

For acidic dissolution, metals/metalloids dissolved with $\mathrm{P}$ should be separated to improve the quality of recovered product, which requires additional energy or chemical input. Direct alkalic extraction can avoid the dissolution of interfering metals, but it does not apply to all sludgederived ash and hydrochar due to limited amount of NAIP. Therefore, several studies proposed the combined sequential extraction procedures to maximize extracted $\mathrm{P}$ and minimize leached metals/metalloids (Fig. 9).

These sequential processes in Fig. 9 can be categorized into three types based on the mechanisms: 1 ) Transforming Ca-P to Al-P and/or Fe$\mathrm{P}$ under controlled $\mathrm{pH}$ around 3-4, e.g., Processes A-C; 2) eluting heavy metals by chelating agent (EDTA), e.g., Process D; and 3) adsorption-desorption, e.g., Process E. Table 3 evaluates the advantages and challenges of using these extraction methods.

In Process A, firstly an acidic elution $(\mathrm{pH}=\sim 3)$ was applied to dissolve Ca-P and reform $\mathrm{P}$ as $\mathrm{AlPO}_{4}\left(\mathrm{~K}_{\mathrm{sp}}=9.8 \times 10^{-21}\right)$ precipitates simultaneously $(0.4 \mathrm{~N} \mathrm{HCl}, \mathrm{L} / \mathrm{S}=10 \mathrm{~mL} / \mathrm{g}, 24 \mathrm{~h})$. Reactions are illustrated in Eqs. (16)-(18) [52]. It was found that when the reaction $\mathrm{pH}$ was maintained in 3-4, most Ca along with heavy metals was removed as ions in the liquid stream by the subsequent dewatering process. On the contrary, most Al, Fe, and P stayed in the solid phase [52,106]. It is worth noting that the optimal $\mathrm{pH}$ for elution varies by the compositions of ash and hydrochar. $\mathrm{P}$ in the form of amorphous $\mathrm{AlPO}_{4}$ can be easily extracted by the following alkaline solution without concerns of heavy metals leaching. However, it was noted that limited P (50\%) could be extracted from Fe-rich ash using this method [52]. This may be because most $\mathrm{Fe}$ exists as acid-insoluble hematite $\left(\mathrm{Fe}_{2} \mathrm{O}_{3}\right)$ in sludge-derived ash, thus leached Fe cations are insufficient for forming Fe-P (nearly no dissolved $\mathrm{Fe}$ for $\mathrm{pH}>2$ ) $[52,116]$.

$\mathrm{Ca}_{9} \mathrm{Al}\left(\mathrm{PO}_{4}\right)_{7}+21 \mathrm{HCl} \rightarrow 9 \mathrm{Ca}^{2+}+\mathrm{Al}^{3+}+\mathrm{H}_{3} \mathrm{PO}_{4}+21 \mathrm{Cl}^{-}$

$\mathrm{Al}(\mathrm{OH})_{3}+3 \mathrm{H}^{+} \rightarrow \mathrm{Al}^{3+}+3 \mathrm{H}_{2} \mathrm{O}$

$\mathrm{Al}^{3+}+\mathrm{H}_{3} \mathrm{PO}_{4} \rightarrow \mathrm{AlPO}_{4} \downarrow+3 \mathrm{H}^{+}$

Process B is similar to Process A. However, instead of using weak acid for elution, Process B initially dosed a strong acid solution $(1 \mathrm{~N} \mathrm{HCl}, \mathrm{L} / \mathrm{S}$ $=10 \mathrm{~mL} / \mathrm{g}, 24 \mathrm{~h}$ ) to dissolve almost all $\mathrm{P}$ (leachate $\mathrm{pH}=\sim 1$ ) [51]. Without separation, the reaction $\mathrm{pH}$ was then raised to 4 for Al-P precipitation, whereas $\mathrm{Ca}$ and most heavy metals remaining in the liquid stream can be washed away. A higher P extraction efficiency may be achieved than Process A due to the lower elution $\mathrm{pH}$, but this has not been demonstrated by comparison studies. Higher amounts of chemicals are required than Process $A$ for the extra dosage of acid and base. Both Processes $\mathrm{A}$ and $\mathrm{B}$ did not use $\mathrm{H}_{2} \mathrm{SO}_{4}$ for pre-elution to avoid the formation of insoluble $\mathrm{CaSO}_{4}$.

Process $\mathrm{C}$ also used an excessive amount of acid to dissolve most $\mathrm{P}$ in the first step $\left(0.2 \mathrm{~N} \mathrm{H}_{2} \mathrm{SO}_{4}, \mathrm{~L} / \mathrm{S}=20 \mathrm{~mL} / \mathrm{g}, 2 \mathrm{~h}\right)$. After filtration, P was precipitated as $\mathrm{Al}-\mathrm{P} / \mathrm{Fe}-\mathrm{P}$ from the leachate by adjusting $\mathrm{pH}$ from 1.5 to 3 [125]. Different from Processes A and B, this procedure used acid to redissolve $\mathrm{P}$ precipitates, and the extract was further washed with cation exchange resin (CER) for a high-purity product. Although it could be applicable for both Al-rich and Fe-rich feedstocks, it involves additional chemicals and equipment. The use of CER did not improve purity (76\%) of recovered fertilizer [125]. Further optimization is necessary for Process $\mathrm{C}$. 

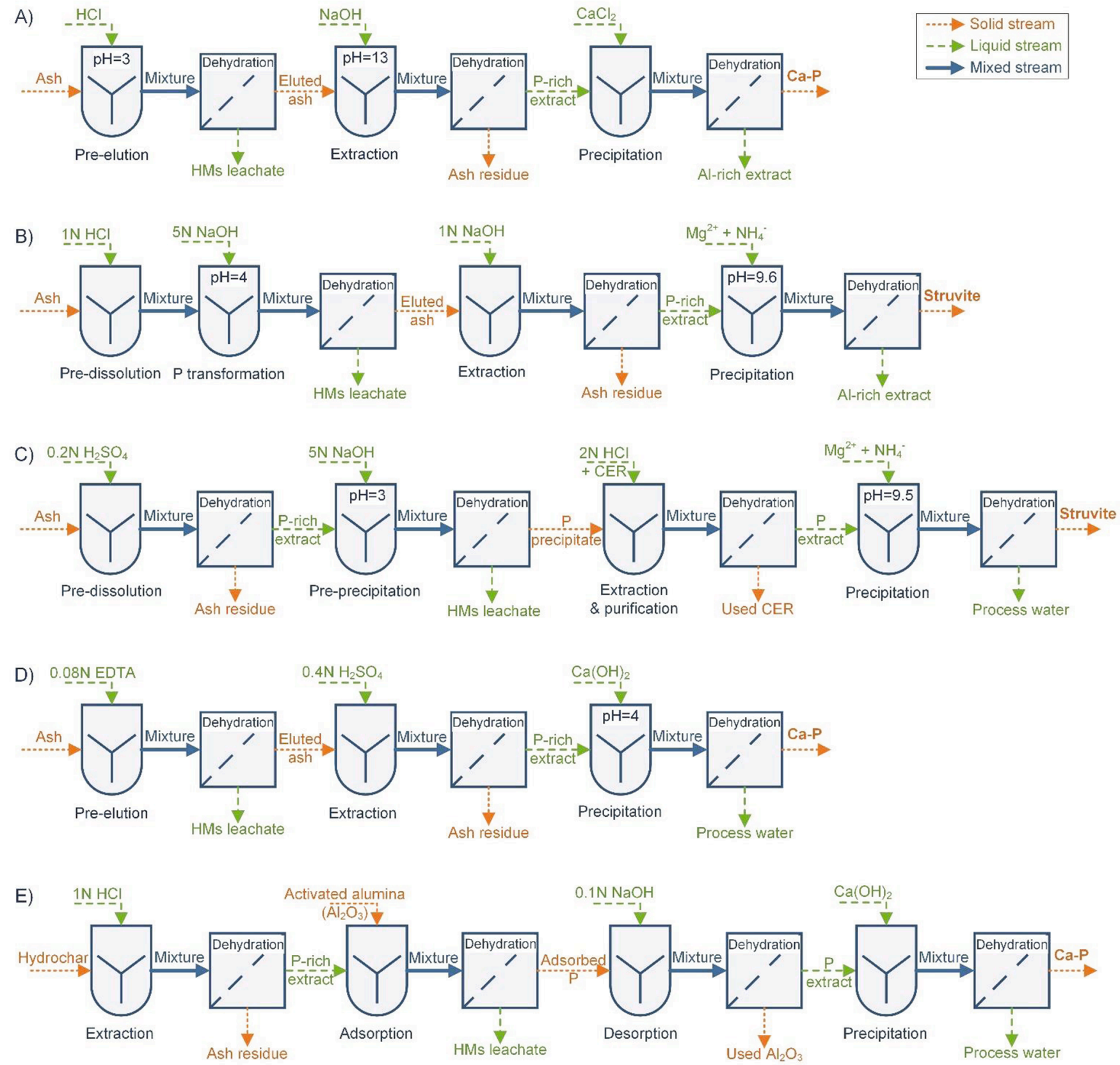

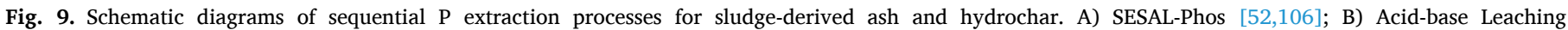

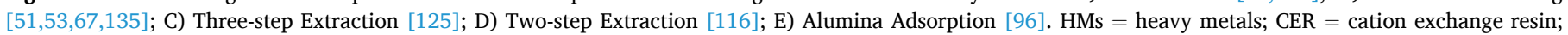
EDTA $=$ ethylenediaminetetraacetic acid.

Unlike Processes A-C, process D utilized chelating agent - EDTA to remove heavy metals by forming metal-EDTA complexes. The eluted ash can be extracted by a strong acid solution to obtain the most $\mathrm{P}$ and limited heavy metals. However, due to the significant loss of P (21\%) during elution, the $\mathrm{P}$ extraction efficiency by this process was relatively low [116]. Meanwhile, not all heavy metals (especially for $\mathrm{Cu}, \mathrm{Ni}$, and $\mathrm{Zn}$ ) can be diminished from the extracts. Moreover, the cost of EDTA is very high ( $\$ 2000 /$ tonne). The use of $\mathrm{H}_{2} \mathrm{SO}_{4}$ for the 2nd extraction caused a high content of $\mathrm{CaSO}_{4}(68 \%$ by weight) in the recovered material, further limiting the recovery value. Therefore, alternative chelating agents may be explored to minimize P loss, improve heavy metals removal, and reduce the cost.

Process E used activated alumina $\left(\mathrm{Al}_{2} \mathrm{O}_{3}\right)$ to adsorb $\mathrm{P}$ from the acidic extract and desorb $\mathrm{P}$ using subsequent alkalic extraction. The involved reactions are shown by Eqs. (19) and (20) [96]. Based on the equations, there is no need to adjust $\mathrm{pH}$ during the acidic adsorption and alkalic desorption steps, and the alumina only works as an adsorbent that can be reused. However, due to the co-adsorption of heavy metals (e.g., $\mathrm{Cr}$ and $\mathrm{Zn}$ ) from the acidic extract, regeneration of alumina is necessary, and its reusability requires examination. Furthermore, a large amount of powdered alumina is needed for its low adsorption capacity (e.g., 6.2 and $15.4 \mathrm{mg} \mathrm{P} / \mathrm{g}$ alumina for solutions with 15 and $50 \mathrm{mg} \mathrm{P} / \mathrm{L}$, respectively).

$\mathrm{Al}_{2} \mathrm{O}_{3}+3 \mathrm{H}_{2} \mathrm{O} \rightarrow \mathrm{Al}(\mathrm{OH})_{3}$

$2 \mathrm{Al}(\mathrm{OH})_{3}+\mathrm{H}_{2} \mathrm{PO}_{4}^{-} \rightleftharpoons \mathrm{AlPO} \mathrm{O}_{4}+\mathrm{OH}^{-}+2 \mathrm{H}_{2} \mathrm{O}$

The above sequential extraction methods have noticeable advantages of depolluting heavy metals from extracts using relatively simple procedures. They also provide alternative options for recovering P from 
Table 3

Evaluations of the state of various sequential $\mathrm{P}$ extraction processes.

\begin{tabular}{|c|c|c|}
\hline Processes & Advantages & Challenges \\
\hline $\begin{array}{l}\text { A) SESAL- } \\
\text { Phos }\end{array}$ & $\begin{array}{l}\text { o Limited extraction of } \\
\text { heavy metals } \\
\text { o No required separation of } \\
\text { interfering metals from } \\
\text { extracts } \\
\text { o Reduced chemical } \\
\text { demand } \\
\text { o Reusable alkalic extracts } \\
\text { as Al-precipitant }\end{array}$ & $\begin{array}{l}\text { - Feedstock selective (efficient } \\
\text { only for Al-rich material) } \\
\text { - Low P extraction efficiency (up } \\
\text { to } 78 \% \text { ) } \\
\text { - Lack of economic analysis } \\
\text { - Unknown disposal of ash residue }\end{array}$ \\
\hline $\begin{array}{l}\text { B) Acid-base } \\
\text { Leaching }\end{array}$ & $\begin{array}{l}\text { o Modified from SESAL- } \\
\text { Phos } \\
\text { o Improved P extraction } \\
\text { efficiency (up to 86\%) } \\
\text { o Heavy metals in } \\
\text { recovered fertilizer } \\
\text { below regulatory limits } \\
\text { o Possible financial return } \\
\text { (limited study) }\end{array}$ & $\begin{array}{l}\text { - Feedstock selective } \\
\text { - Additional chemical demand for } \\
\text { pH control } \\
\text { - Unknown disposal of ash residue } \\
\text { - Detailed cost analysis needed }\end{array}$ \\
\hline $\begin{array}{l}\text { C) Three-step } \\
\text { Extraction }\end{array}$ & $\begin{array}{l}\text { o Applicable for } \mathrm{Al} / \mathrm{Fe}-\text { rich } \\
\text { material } \\
\text { o Desirable P extraction } \\
\text { efficiency }(80 \%) \\
\text { o Further removal of } \mathrm{Al} / \mathrm{Fe} \\
\text { ions from extract } \\
\text { o Heavy metals in } \\
\text { recovered fertilizer } \\
\text { below regulatory } \\
\text { standards }\end{array}$ & $\begin{array}{l}\text { - Complex process } \\
\text { - Extra chemical, equipment, and } \\
\text { energy demand } \\
\text { - Additional cost for resin } \\
\text { regeneration (optional if no } \\
\text { requirement on product purity) } \\
\text { - Lack of economic analysis } \\
\text { - Unknown disposal of byproducts } \\
\text { (ash residue and process water) }\end{array}$ \\
\hline $\begin{array}{l}\text { D) Two-step } \\
\text { Extraction }\end{array}$ & $\begin{array}{l}\text { o No requirement on } \\
\text { feedstock } \\
\text { o Less extracted heavy } \\
\text { metals than acidic } \\
\text { extraction } \\
\text { o Possible financial return } \\
\text { (limited study) } \\
\text { o Desirable chemical } \\
\text { demand }\end{array}$ & $\begin{array}{l}\text { - Low P extraction efficiency } \\
\text { ( } 73 \% \text { ) due to elution loss } \\
\text { - Ordinary removal of heavy } \\
\text { metals } \\
\text { - Low purity of recovered material } \\
\text { - Expensive chemical (EDTA) } \\
\text { - Detailed economic analysis } \\
\text { needed } \\
\text { - Unknown disposal of byproducts } \\
\text { (ash residue and process water) }\end{array}$ \\
\hline $\begin{array}{l}\text { E) Alumina } \\
\text { Adsorption }\end{array}$ & $\begin{array}{l}\text { o No requirement on } \\
\text { feedstock } \\
\text { o Desirable P extraction } \\
\text { efficiency (>91\%) } \\
\text { o Low heavy metals } \\
\text { contents in extracts } \\
\text { o Reusable sorbent and } \\
\text { process water }\end{array}$ & $\begin{array}{l}\text { - High demand on adsorbent } \\
\text { - Lack of comprehensive study } \\
\text { - Unknown reusability of } \\
\text { adsorbent } \\
\text { - Lack of economic analysis } \\
\text { - Unknown disposal of byproducts } \\
\text { (ash residue and leachate) }\end{array}$ \\
\hline
\end{tabular}

ash and hydrochar with complex compositions. It is worthy to further develop the sequential $\mathrm{P}$ extraction approaches by addressing the process challenges and investigating their technical and economic feasibility for large-scale applications. Detailed economic analysis and more comprehensive examinations are needed to verify their applicability to various ash and hydrochar. Process optimizations, such as finding cheaper extractants, recycling process water, lowering $\mathrm{L} / \mathrm{S}$ ratio and extraction time, and improving extraction efficiency, are demanded for cost-effectiveness.

\section{P recovery as fertilizers by precipitation}

After liquid extraction, $\mathrm{P}$ is often recovered as solid fertilizers by the subsequent chemical precipitation for its high recovery rate and economic efficiency, allowing easy transportation and storage. Three major crystallization processes are commonly considered to produce $\mathrm{P}$ fertilizers from wastewater streams: Struvite $\left(\mathrm{MgNH}_{4} \mathrm{PO}_{4} \cdot 6 \mathrm{H}_{2} \mathrm{O}\right)$, Ca-P, and vivianite $\left.\left[\mathrm{Fe}_{3}\left(\mathrm{PO}_{4}\right)_{2} \cdot 8 \mathrm{H}_{2} \mathrm{O}\right)\right]$. The mechanisms of crystallization can be briefly described as: 1) Crystal formation through primary nucleation by foreign particles or supersaturation conditions, 2) crystal growth via secondary nucleation by mass transfer and surface integration, and 3) aggregation of crystals $[136,137]$. Table 4 compares the three crystallization processes and Table 5 summarizes the common precipitants used for each process. The review about effects of operational factors (e. g., $\mathrm{pH}$, temperature, mixing, precipitants, molar ratio, seeding, foreign ions, organic matter, and reactor types) on the crystallization processes can be found elsewhere $[1,2,36,39]$.

\subsection{Struvite}

Struvite crystallization has been widely developed to recover $\mathrm{P}$ from both ash and hydrochar derived from municipal sludge (Table 6). Theoretically, struvite starts to form at a $\mathrm{Mg}^{2+}: \mathrm{NH}_{4}^{+}: \mathrm{PO}_{4}^{3-}$ molar ratio of 1:1:1 under saturation conditions as shown in Eq. (21) (Table 4). The solution saturation condition can be indicated by the saturation index (SI), which is defined as the ion activity product (IAP) of constituent ions over the equilibrium solubility product $\left(\mathrm{K}_{\mathrm{sp}}\right)$ of the precipitate, as described in Eqs. (27) and (28) [143]. Precipitation does not occur when the system is undersaturated (SI $<0$ ), while it happens under supersaturated conditions (SI $>0$ ). Due to the complex contents of $P$ extracts, two chemical equilibrium modeling programs, Visual MINTEQ and PHREEQC, have been widely used to estimate SI values based on the inputs of ion concentrations, $\mathrm{pH}$, and temperature of the solution [36]. The saturation point of struvite is highly affected by the solution $\mathrm{pH}$, with a favorable range of 8-10. Increasing ions concentrations and $\mathrm{pH}$ can enhance the solution saturation, but a $\mathrm{pH}$ higher than 10.5 leads to the sharp decrease of $\mathrm{NH}_{4}^{+}$and inhibit the formation of struvite [39].

$I A P=\left\{\mathrm{Mg}^{2+}\right\}\left\{\mathrm{NH}_{4}{ }^{+}\right\}\left\{\mathrm{PO}_{4}{ }^{3-}\right\}$

$S I=\log \left(I A P / K_{s p}\right)$

where \{\} donates the effective concentration or activity of ions.

In real precipitation process, the optimal $\mathrm{pH}$ and $\mathrm{Mg}: \mathrm{N}: \mathrm{P}$ molar ratio vary due to the complex contents of sludge-derived ash and hydrochar and their extracts. Supplemental $\mathrm{Mg}^{2+}$ and $\mathrm{NH}_{4}^{+}$chemicals are typically needed due to their low concentrations in extracts. Liang et al. reported that at $\mathrm{pH} 9$ and $\mathrm{Mg}: \mathrm{N}: \mathrm{P}$ of 1:1:1, over $98 \%$ of $\mathrm{P}$ can be precipitated from acidic extract within $40 \mathrm{~min}$ [62]. Similarly, another study also obtained $99 \%$ of $\mathrm{P}$ precipitation efficiency at $\mathrm{Mg}: \mathrm{N}: \mathrm{P}=1: 1: 1$ and $\mathrm{pH} 9.5$ in $2 \mathrm{~h}$ [125]. However, $\mathrm{Xu}$ et al. found that more $\mathrm{MgCl}_{2} \cdot 6 \mathrm{H}_{2} \mathrm{O}$ and $\mathrm{NH}_{4} \mathrm{Cl}$ and higher $\mathrm{pH}$ were added for struvite formation from acidic extracts and the optimal conditions were $\mathrm{Mg}: \mathrm{N}: \mathrm{P}=1.6: 1.6: 1$ at $\mathrm{pH} 10$, with the influence ranked as $\mathrm{pH}>\mathrm{N}: \mathrm{P}>\mathrm{Mg}: \mathrm{P}$ [55]. Some studies indicated that the optimal P ( $>97 \%)$ and $\mathrm{N}$ recovery $(>70 \%)$ from alkaline extracts were reached at higher $\mathrm{Mg}: \mathrm{P}(>1.5)$ and lower $\mathrm{N}: \mathrm{P}(0.6)$ molar ratios at $\mathrm{pH}>$ $9.3[53,135]$. It is noticed that using $\mathrm{Mg}$ salts (e.g., $\mathrm{MgCl}_{2}$ ) can achieve a high $\mathrm{P}$ precipitation efficiency $(\geq 87 \%)$ within a short period $(\leq 2 \mathrm{~h})$, while using cheaper but water-insoluble $\mathrm{MgO}$ could cause many issues, such as lower efficiency, longer retention time, larger reactor volume, or even blockage [41]. K-struvite $\left(\mathrm{MgKPO}_{4} \cdot 6 \mathrm{H}_{2} \mathrm{O}\right)$ is another form of struvite, which replaces $\mathrm{NH}_{4}^{+}$with $\mathrm{K}^{+}$under higher $\mathrm{pH}$ at 11 . One study found that sludge-derived hydrochar showed a high potential of $\mathrm{P}$ recovery ( $\geq 88 \%$ overall $\mathrm{P}$ recovery) as K-struvite $\left(\mathrm{K}_{\mathrm{sp}}=\sim 10^{-22}\right.$ ) through $\mathrm{KOH}$ extraction and subsequent crystallization with additional $\mathrm{MgCl}_{2}$ [97]. However, both $\mathrm{KOH}$ and $\mathrm{MgCl}_{2}$ are expensive chemicals, which would increase the overall costs. Abbona et al. found that a small amount of $\mathrm{Ca}^{2+}$ (e.g., Ca:P $=0.1$ ) could largely reduce the purity of struvite, especially at low $\mathrm{pH}$ due to the substitution of brushite or amorphous Ca-P for their low induction time, while high $\mathrm{Mg}$ content and high $\mathrm{pH}$ are needed to overcome this challenge [144]. The use of Ca $(\mathrm{OH})_{2}$ for $\mathrm{pH}$ adjustment for struvite precipitation is also discouraged [145]. The tradeoffs among chemical consumption, purity, and market values of recovered products should be considered in the cost optimization.

Although additional ammonium source is needed to promote the formation of struvite, it also provides the opportunities of recovering $\mathrm{N}$ from waste streams, such as ammonium-rich wastewater. Adding food processing wastewater $\left(27,096.5 \mathrm{mg} / \mathrm{L} \mathrm{NH}_{4}^{-}-\mathrm{N}\right)$ to alkaline extracts, 
Table 4

Comparison of $\mathrm{P}$ recovery crystallization processes $[1,2,36,41,138-140]$.

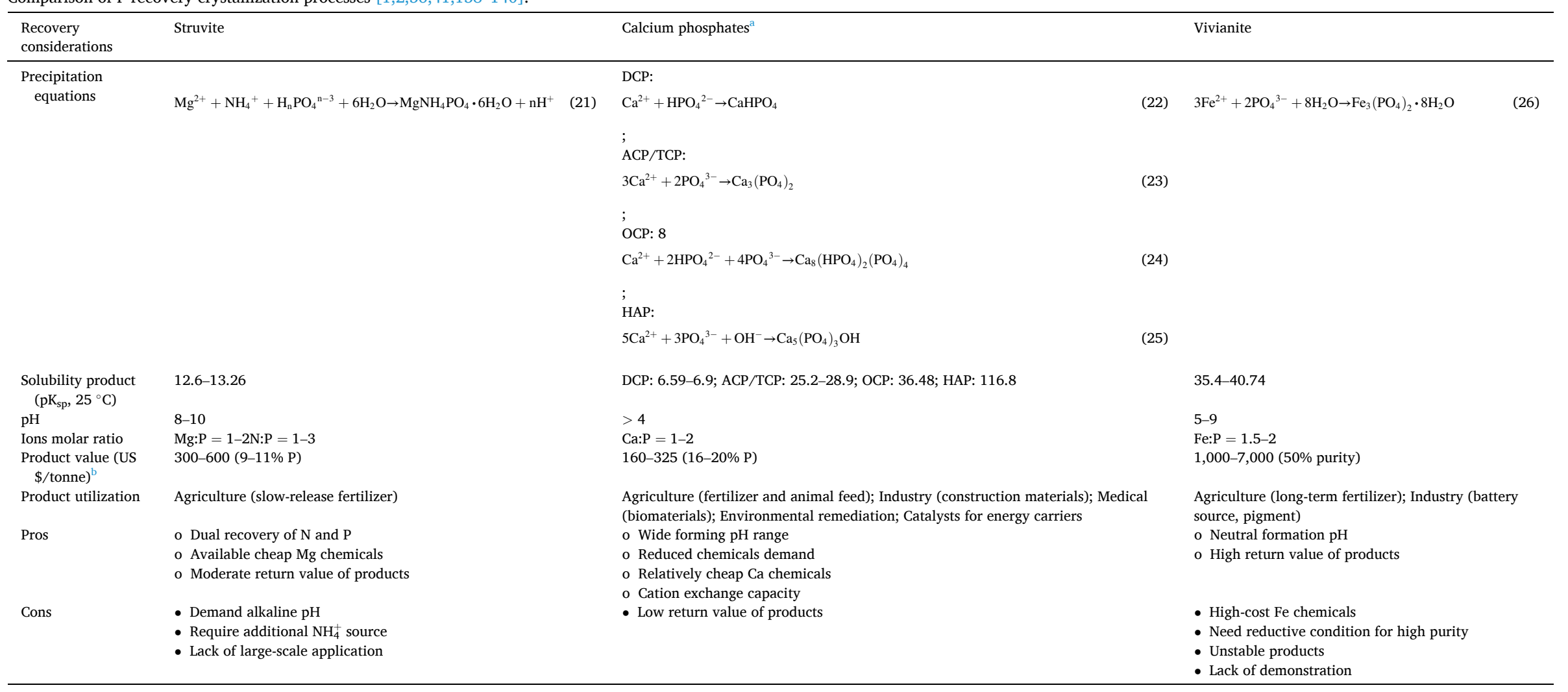

\footnotetext{
a $\mathrm{HAP}=$ hydroxyapatite; $\mathrm{DCP}=$ dicalcium phosphate; $\mathrm{ACP}=$ amorphous calcium phosphate; $\mathrm{TCP}=$ tricalcium phosphate; $\mathrm{OCP}=$ octacalcium phosphate

${ }^{b}$ Prices obtained from Alibaba [141].
} 
Table 5

Commercial precipitants used for P crystallization $[1,2,36]$.

\begin{tabular}{|c|c|c|c|c|c|}
\hline Type & Precipitants & Contents & $\begin{array}{l}\text { Solubility in water }(\mathrm{g} / \\
\mathrm{L})^{\mathrm{a}}\end{array}$ & $\begin{array}{l}\text { Costs (US } \\
\$ / \mathrm{mol})^{\mathrm{b}}\end{array}$ & Remarks \\
\hline \multirow{4}{*}{$\begin{array}{l}\text { Oxygen-bearing } \\
\text { minerals }\end{array}$} & Magnesia & $94 \% \mathrm{MgO}$ & $0.09\left(30^{\circ} \mathrm{C}\right)$ & $0.006-0.008$ & \multirow{12}{*}{$\begin{array}{l}\text { - Low-cost but less efficient } \\
\text { - More alkaline, reducing alkalinity consumption } \\
\text { - Poorly soluble, applicable for acidic extracts }\end{array}$} \\
\hline & Brucite & $90 \% \mathrm{Mg}(\mathrm{OH})_{2}$ & $0.009\left(18^{\circ} \mathrm{C}\right)$ & $0.009-0.013$ & \\
\hline & Quicklime & $90 \% \mathrm{CaO}$ & $1.19\left(25^{\circ} \mathrm{C}\right)$ & $0.004-0.006$ & \\
\hline & Hydrated lime & $90 \% \mathrm{Ca}(\mathrm{OH})_{2}$ & $1.59\left(25^{\circ} \mathrm{C}\right)$ & $0.007-0.008$ & \\
\hline \multirow[t]{8}{*}{ Salts } & Magnesium chloride & $99 \%$ & \multirow[t]{2}{*}{$543\left(20^{\circ} \mathrm{C}\right)$} & \multirow[t]{2}{*}{$0.027-0.041$} & \\
\hline & hexahydrate & $\mathrm{MgCl}_{2} \cdot 6 \mathrm{H}_{2} \mathrm{O}$ & & & \\
\hline & Magnesium sulphate & $99 \%$ & \multirow[t]{2}{*}{$360\left(20^{\circ} \mathrm{C}\right)$} & \multirow[t]{2}{*}{$0.020-0.037$} & \\
\hline & heptahydrate & $\mathrm{MgSO}_{4} \cdot 7 \mathrm{H}_{2} \mathrm{O}$ & & & \\
\hline & Calcium chloride & $94 \% \mathrm{CaCl}_{2}$ & $813\left(25^{\circ} \mathrm{C}\right)$ & $0.014-0.019$ & \\
\hline & Ferrous sulphate & $98 \%$ & $256\left(20^{\circ} \mathrm{C}\right)$ & $0.017-0.023$ & \\
\hline & heptahydrate & $\mathrm{FeSO}_{4} \cdot 7 \mathrm{H}_{2} \mathrm{O}$ & & & \\
\hline & Ferrous chloride tetrahydrate & $98 \% \mathrm{FeCl}_{2} \cdot 4 \mathrm{H}_{2} \mathrm{O}$ & $625\left(20^{\circ} \mathrm{C}\right)$ & $0.020-0.041$ & \\
\hline
\end{tabular}

\footnotetext{
a Data obtained from PubChem [142].
}

b Prices obtained from Alibaba [141].

total recovery of $72.7 \% \mathrm{P}$ and $64.9 \% \mathrm{NH}_{4}^{+}-\mathrm{N}$ were achieved from sludgederived ash and wastewater, respectively [53]. HTL treatment of municipal sludge generates two major waste streams: P-rich hydrochar and ammonium-rich aqueous phase, which can be exactly utilized as struvite production sources, achieving sustainable nutrients recovery along with the development of continuous-flow HTL system [22]. By combining HTL aqueous and hydrochar acidic extracts, a P precipitation efficiency of over $87 \%$ was achieved at pH 9 [22,127]. Noticeably, the overall $\mathrm{P}$ recovery efficiency from ash and hydrochar tended to be low (as low as 50\%), although the precipitation rates were high. Particularly, in a pilot-scale continuous-flow HTL treatment $\left(350^{\circ} \mathrm{C}, 22 \mathrm{MPa}\right)$, it was reported that total recovery for $\mathrm{P}$ based on the sludge feedstock was only $23.7 \%$. The low overall efficiency was caused by the dispersion of Pcontaining particles in biocrude (33\% P of sludge) during HTL phase separation and limited extraction efficiency (49.9\% P of hydrochar) during acidic leaching [22]. Therefore, future studies should minimize $P$ loss to other phases and maximize the P extraction efficiency from hydrochar to enhance the overall nutrient recovery efficiency and economic benefits, accomplished with the optimization of the continuousflow HTL operations.

A preliminary economic analysis based on chemical costs and struvite income indicated that struvite precipitation coupled with

Table 6

$\mathrm{P}$ recovery through wet-chemical extraction and precipitation from sludge-derived ash and hydrochar ${ }^{\mathrm{a}}$.

\begin{tabular}{|c|c|c|c|c|c|c|c|}
\hline Feedstock & Extractants & Precipitants & Precipitation conditions & Recovered products & $\begin{array}{l}\text { PPE } \\
(\%)\end{array}$ & $\begin{array}{l}\text { PRE } \\
(\%)\end{array}$ & Ref. \\
\hline \multirow[t]{17}{*}{ Ash } & $0.4 \mathrm{~N} \mathrm{H}_{2} \mathrm{SO}_{4}$ & $\mathrm{NaOH}$ & $\mathrm{pH}=4.4-6.5$ & $\mathrm{AlPO}_{4}, \mathrm{Ca}_{3}\left(\mathrm{PO}_{4}\right)_{2}, \mathrm{FePO}_{4}$ & $>95$ & - & [116] \\
\hline & $\begin{array}{l}0.08 \mathrm{~N} \text { EDTA pre-eluted, } \\
\text { followed by } 0.4 \mathrm{~N} \mathrm{H}_{2} \mathrm{SO}_{4}\end{array}$ & & $\mathrm{pH}=4.4-6.3$ & & $>93$ & - & \\
\hline & $0.4 \mathrm{~N} \mathrm{H}_{2} \mathrm{SO}_{4}$ & $\mathrm{Ca}(\mathrm{OH})_{2}$ & $\mathrm{pH}>5.1$ & & $>99$ & - & \\
\hline & $\begin{array}{l}0.08 \mathrm{~N} \text { EDTA pre-eluted, } \\
\text { followed by } 0.4 \mathrm{~N} \mathrm{H}_{2} \mathrm{SO}_{4}\end{array}$ & & $\mathrm{pH}>5.0$ & & 100 & - & \\
\hline & $2.7 \mathrm{~N} \mathrm{HNO}_{3}$ & $6 \%$ lime milk & $\mathrm{pH}=7.3$ & Dicalcium phosphate & $>90$ & - & [122] \\
\hline & $8.1 \mathrm{~N} \mathrm{H}_{3} \mathrm{PO}_{4}$ & & $\mathrm{pH}=7.0$ & & $>90$ & - & \\
\hline & $8.1 \mathrm{~N} \mathrm{H}_{3} \mathrm{PO}_{4}$ & Hydrated lime & $\mathrm{pH}=6$ & Dicalcium phosphate & 100 & - & [48] \\
\hline & $5.2 \mathrm{~N} \mathrm{HCl}$ & $\mathrm{CaCl}_{2}$ & $\mathrm{pH}=-1.5$ & Monocalcium & 85 & 62 & [82] \\
\hline & $5.2 \mathrm{~N} \mathrm{HCl}$ & $\mathrm{Ca}(\mathrm{OH})_{2}$ & $\mathrm{pH}=-1.2$ & chlorophosphate & 51 & 37 & \\
\hline & $3.9 \mathrm{~N} \mathrm{HCl}$ & $\mathrm{CaCl}_{2}$ & $\mathrm{pH}=-1.1$ & & 70 & 51 & \\
\hline & $\begin{array}{l}\mathrm{HCl} \text { pre-eluted }(\mathrm{pH}=3) \\
\text { followed by } \mathrm{NaOH}(\mathrm{pH}=13)\end{array}$ & $\mathrm{CaCl}_{2}$ & $\mathrm{Ca}: \mathrm{P}=1: 1.5$ & Hydroxyapatite & 89.6 & 60 & [106] \\
\hline & $0.5 \mathrm{~N} \mathrm{H}_{2} \mathrm{SO}_{4}$ & $\mathrm{MgCl}_{2} \cdot 6 \mathrm{H}_{2} \mathrm{O}$ and $\mathrm{NH}_{4} \mathrm{Cl}$ & $\begin{array}{l}\text { Mg:N:P }=1: 1: 1, p H=9.0 \text { (purified by } \\
\text { CER) }\end{array}$ & Struvite & 98.3 & 69.1 & [62] \\
\hline & $0.5 \mathrm{~N}$ oxalic acid & $\mathrm{NaOH}$ & $\mathrm{pH}=9.0$ & $\begin{array}{l}\text { Aluminum and iron } \\
\text { hydroxyphosphates }\end{array}$ & 78.8 & 65.5 & \\
\hline & $\begin{array}{l}\mathrm{HCl} \text { pre-eluted }(\mathrm{pH}=4) \\
\text { followed by } 1 \mathrm{~N} \mathrm{NaOH}\end{array}$ & $\begin{array}{l}\mathrm{MgCl}_{2} \cdot 6 \mathrm{H}_{2} \mathrm{O} \text { and } \mathrm{NH}_{4}^{+}- \\
\text {rich food wastewater }\end{array}$ & $\mathrm{Mg}: \mathrm{N}: \mathrm{P}=2: 0.6: 1, \mathrm{pH}=9.28$ & Struvite & 99.9 & 72.7 & [53] \\
\hline & $\begin{array}{l}\mathrm{HCl} \text { pre-eluted }(\mathrm{pH}=4) \\
\text { followed by } 1 \mathrm{~N} \mathrm{NaOH}\end{array}$ & $\begin{array}{l}\mathrm{MgCl}_{2} \cdot 6 \mathrm{H}_{2} \mathrm{O} \text { and } \mathrm{NH}_{4}^{+}- \\
\text {rich food wastewater }\end{array}$ & $\mathrm{Mg}: \mathrm{N}: \mathrm{P}=1.59: 0.6: 1, \mathrm{pH}=9.63$ & Struvite & 97.9 & 70.9 & [135] \\
\hline & $0.2 \mathrm{~N} \mathrm{H}_{2} \mathrm{SO}_{4}$ & $\mathrm{MgCl}_{2} \cdot 6 \mathrm{H}_{2} \mathrm{O}$ and $\mathrm{NH}_{4} \mathrm{Cl}$ & $\begin{array}{l}\text { Mg:N:P }=1: 1: 1, \mathrm{pH}=9.5 \text { (purified by } \\
0.5 \text { g/mL CER) }\end{array}$ & Struvite & 99.2 & 79.7 & [125] \\
\hline & $0.2 \mathrm{~N} \mathrm{HCl}$ & $\mathrm{MgCl}_{2} \cdot 6 \mathrm{H}_{2} \mathrm{O}$ and $\mathrm{NH}_{4} \mathrm{Cl}$ & $\begin{array}{l}\mathrm{Mg}: \mathrm{N}: \mathrm{P}=1.6: 1.6: 1, \mathrm{pH}=10 \text { (purified } \\
\text { by } 0.04 \mathrm{~g} / \mathrm{mL} \text { CER) }\end{array}$ & Struvite & 97.2 & $85-95$ & [55] \\
\hline \multirow[t]{5}{*}{ Hydrochar } & $\begin{array}{l}1 \mathrm{~N} \mathrm{HCl}+\text { activated alumina, } \\
\text { followed by } 0.1 \mathrm{~N} \mathrm{NaOH}\end{array}$ & $\mathrm{Ca}(\mathrm{OH})_{2}$ & $\mathrm{pH}=9$ & Calcium phosphate & $>97$ & $>85$ & [96] \\
\hline & Citric acid $(\mathrm{pH}=2)$ & $\begin{array}{l}\mathrm{MgCl}_{2} \text { and } \mathrm{NH}_{4}^{+} \text {-rich } \mathrm{HTC} \\
\text { aqueous }\end{array}$ & Mg:N:P = 1.3:1:1, $\mathrm{pH}=9$ & Struvite & 87 & - & [127] \\
\hline & $\mathrm{KOH}(\mathrm{pH}=12)$ & $\mathrm{MgCl}_{2} \cdot 6 \mathrm{H}_{2} \mathrm{O}$ & $\begin{array}{l}\mathrm{Mg}: \mathrm{P}=2: 1, \mathrm{pH}=11 \text { (EDTA chelated to } \\
\text { prevent interferential precipitation) }\end{array}$ & K-struvite & 92 & 88 & [97] \\
\hline & & & $\mathrm{Mg}: \mathrm{P}=2.5: 1, \mathrm{pH}=11$ (EDTA chelated) & & 99 & 95 & \\
\hline & $\mathrm{H}_{2} \mathrm{SO}_{4}(\mathrm{pH}=2)$ & $\begin{array}{l}\mathrm{MgCl}_{2} \cdot 6 \mathrm{H}_{2} \mathrm{O} \text { and } \mathrm{NH}_{4}^{+}- \\
\text {rich HTL aqueous }\end{array}$ & $\mathrm{Mg}: \mathrm{N}: \mathrm{P}=2.6: 1.1: 1, \mathrm{pH}=9$ & Struvite & 99 & 50.7 & {$[22]$} \\
\hline
\end{tabular}

${ }^{a}$ PPE = phosphorus precipitation efficiency (from solution); PRE = phosphorus recovery efficiency (from feedstock); Ref. = references; CER = cation exchange resin; EDTA = ethylenediaminetetraacetic acid; HTC = hydrothermal carbonization; HTL = hydrothermal liquefaction; "-" donates "not available". 

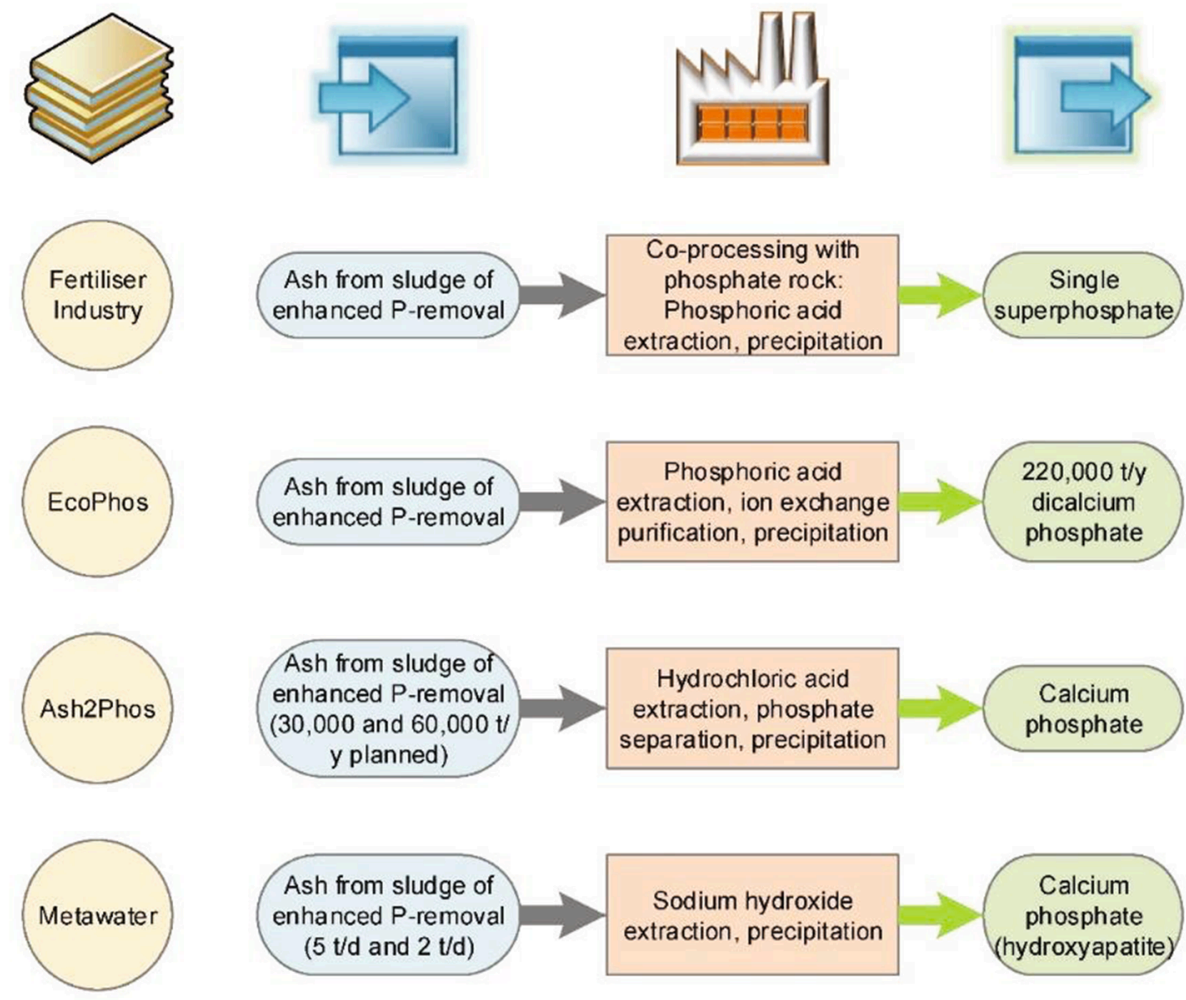

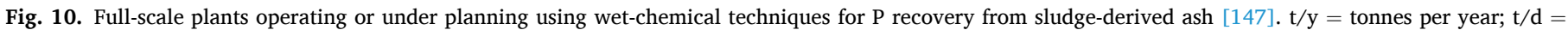
tonnes per day.

hydrothermal treatment of municipal sludge can be marginally profitable, primarily due to the addition of costly $\mathrm{Mg}$ salt $\left(\mathrm{MgCl}_{2}\right)$ [146]. Thus, alternative chemicals and methods should be applied to optimize nutrient recovery. Many research gaps also require attention, such as the reusability and disposal of post-recovery processing water, the utilization of solid residue (i.e., hydrochar after P extraction), comprehensive cost analysis of each recovery process, etc.

\subsection{Calcium phosphates}

Ca-P as commercially available products, their precipitation is a common $\mathrm{P}$ recovery pathway for sludge-derived ash and hydrochar. According to the inventory by the European Sustainable Phosphorus Platform, Ca-P are the only fertilizer products that have been recovered under full-scale applications of wet-chemical extraction and precipitation from sludge-derived ash (Fig. 10) [147]. Depending on the solution $\mathrm{pH}$ and kinetics, various forms of Ca-P can exist in precipitates: Dicalcium phosphate $\left(\mathrm{CaHPO}_{4}\right)$, octacalcium phosphate $\left[\mathrm{Ca}_{8} \mathrm{H}_{2}\left(\mathrm{PO}_{4}\right)_{6} \cdot 5 \mathrm{H}_{2} \mathrm{O}\right]$ and hydroxyapatite $\left[\mathrm{Ca}_{5}\left(\mathrm{PO}_{4}\right)_{3} \mathrm{OH}\right]$ are stable at $\mathrm{pH}$ around 5,6 and above 7 , respectively; however, the precipitated phases will eventually recrystallize as hydroxyapatite that is thermodynamically more stable [41]. It was found that with a phosphate concentration of $0.01-0.5 \mathrm{M}$, the precipitates occurred in the order of brushite $\left(\mathrm{CaHPO}_{4} \cdot 2 \mathrm{H}_{2} \mathrm{O}\right)$, monetite $\left(\mathrm{CaHPO}_{4}\right)$, and amorphous Ca-P $\left[\mathrm{Ca}_{3}\left(\mathrm{PO}_{4}\right)_{2} \cdot \mathrm{xH}_{2} \mathrm{O}\right]$, which were controlled by solution $\mathrm{pH}$ [144]. Unlike struvite, Ca-P can reach supersaturation and precipitate at a very low $\mathrm{pH}(>4)$. It is found that adding $\mathrm{Ca}$ chemicals with a solution $\mathrm{pH}$ above 5 could result in a high $\mathrm{P}$ precipitation efficiency of $>89 \%$ from leachates of sludge-derived ash and hydrochar (Table 6). However, due to the co-dissolved $\mathrm{Al}$ and Fe cations during acidic extraction, a large portion of phosphate could exist in the form of undesirable $\mathrm{AlPO}_{4}\left(\mathrm{pK}_{\mathrm{sp}}=20\right)$ and/or $\mathrm{FePO}_{4}\left(\mathrm{pK}_{\mathrm{sp}}=15\right)$ combined with their hydroxides when precipitation at moderate $\mathrm{pH}$ (4.4-6.5), which reduces the plant availability of recovered products $[62,116]$. Therefore, pre-treatment or purification might be needed to remove interference ions before precipitation. It was suggested that oxalic acid extraction could lead to unremovable $\mathrm{Al}$ and $\mathrm{Fe}$ ions by CER because they formed $\mathrm{Al}\left(\mathrm{C}_{2} \mathrm{O}_{4}\right)_{2}^{-}, \mathrm{Al}\left(\mathrm{C}_{2} \mathrm{O}_{4}\right)_{3}^{3-}, \mathrm{Fe}\left(\mathrm{C}_{2} \mathrm{O}_{4}\right)_{2}^{-}$, and $\mathrm{Fe}\left(\mathrm{C}_{2} \mathrm{O}_{4}\right)_{3}^{3-}$ complexes, and therefore $\mathrm{P}$ was recovered as low-value $\mathrm{AlPO}_{4}$-based product during precipitation [62]. Enhancing precipitation $\mathrm{pH}$ could also overcome the co-precipitation of $\mathrm{Al}$ as it predominates as a soluble anion, $\mathrm{Al}(\mathrm{OH})_{4}^{-}$, in alkalic solution $(\mathrm{pH}>10)$ [116]. Therefore, the compatibility of extractants and the subsequent target fertilizers from precipitation should be carefully considered to avoid the generation of low-value Al-P or Fe(III)-P.

Typically, lime $(\mathrm{CaO}), \mathrm{Ca}(\mathrm{OH})_{2}$, and $\mathrm{CaCl}_{2}$ are supplied to $P$ extracts to achieve specific stoichiometric molar ratios (Ca:P $=1-1.67)$ and precipitate Ca-P, whereas a higher amount of Ca demand might be needed due to the co-precipitation of gypsum $\left(\mathrm{CaSO}_{4}\right)$ and carbonate $\left(\mathrm{CaCO}_{3}\right)[2]$. This not only causes extra chemical costs but also reduces $\mathrm{P}$ contents in recovery products. Such impacts are also related to reaction $\mathrm{pH}$ [41]. It has been suggested that SI values $(>0)$ of hydroxyapatite can be effectively improved by increasing phosphate concentration $(>1.6$ $\mathrm{mg} \mathrm{P} / \mathrm{L}), \mathrm{pH}$ (7-11), or Ca:P ratio (1.67-16.7), and it could also be slightly enhanced by temperature from 5 to $30^{\circ} \mathrm{C}$ [148]. However, there seems a lack of optimization study for Ca-P precipitation from extracts of sludge-derived ash and hydrochar, although high precipitation rates have been achieved in various studies. The retention time for precipitation is generally maintained within $15-120$ min depending on the mixing intensity, but the detailed optimizing process is lacking $[48,61,122]$.

Besides the conventional recovery of Ca-P, Liu and Qu developed a novel method of recovering $\mathrm{P}$ as monocalcium chlorophosphate $\left(\mathrm{CaClH}_{2} \mathrm{PO}_{4} \cdot \mathrm{H}_{2} \mathrm{O}\right)$ crystals under strongly acidic conditions $(\mathrm{pH}<0)$ from sludge-derived ash [82]. The mechanism is that $\mathrm{CaClH}_{2} \mathrm{PO}_{4} \cdot \mathrm{H}_{2} \mathrm{O}$ is the least soluble $\mathrm{P}$ form at a $\mathrm{pH}$ range of $-3-0$ compared to other compounds, except for $\mathrm{CaSO}_{4}$. The advantages were the high product purity and the elimination of undesired impurities (e.g., $\mathrm{AlPO}_{4}$ and $\mathrm{FePO}_{4}$ ) and heavy metals with a simple setup. However, the overall $\mathrm{P}$ recovery 
Table 7

Contents of $\mathrm{P}$ and heavy metals in recovered fertilizers from sludge-derived ash compared to commercial fertilizer (triple superphosphate) ${ }^{\mathrm{a}}$.

\begin{tabular}{|c|c|c|c|c|c|c|c|c|c|c|c|c|}
\hline \multirow[t]{2}{*}{ Recovered products } & \multirow[t]{2}{*}{ Country } & \multirow{2}{*}{$\begin{array}{l}\text { Total P }(\% \\
\left.\mathrm{P}_{2} \mathrm{O}_{5}\right)\end{array}$} & \multirow{2}{*}{$\begin{array}{l}\text { Plant-available P (\% } \\
\left.\mathrm{P}_{2} \mathrm{O}_{5}\right)\end{array}$} & \multicolumn{8}{|c|}{ Heavy metals (mg/kg) } & \multirow[t]{2}{*}{ Ref. } \\
\hline & & & & As & $\mathrm{Cd}$ & $\mathrm{Cr}$ & $\mathrm{Cu}$ & $\mathrm{Hg}$ & $\mathrm{Ni}$ & $\mathrm{Pb}$ & $\mathrm{Zn}$ & \\
\hline \multirow[t]{3}{*}{ Dicalcium phosphate } & Germany & 40.3 & $38.0^{\mathrm{b}}$ & 9.1 & 2.16 & 118 & 663 & 0.7 & 47.3 & 51.4 & 1,580 & [6] \\
\hline & \multirow[t]{2}{*}{ Poland } & 42.85 & $38.22^{\mathrm{b}}$ & - & 52.17 & - & - & - & - & 11.97 & - & \multirow[t]{2}{*}{ [48] } \\
\hline & & 44.77 & $39.48^{\mathrm{b}}$ & - & 16.49 & - & - & - & - & 0.008 & - & \\
\hline Hydroxyapatite & Germany & 35 & - & 27.93 & 0.07 & ND & 4.5 & - & 0.20 & 3.37 & 20.73 & {$[106]^{*}$} \\
\hline \multirow[t]{5}{*}{ Struvite } & Korea & 24.2 & $23.8^{\mathrm{c}}$ & 2.7 & ND & 5.0 & 5.5 & - & 3.2 & ND & 9.0 & {$[53]^{*}$} \\
\hline & Korea & 28.2 & $27.9^{c}$ & 28 & 1 & ND & 3 & - & ND & ND & 44 & {$[135]^{*}$} \\
\hline & China & 32.6 & - & - & - & - & 10.6 & - & - & - & 5.4 & {$[62]^{*}$} \\
\hline & China & - & - & - & - & - & $150-800$ & - & - & - & $260-350$ & [55] \\
\hline & China & - & - & 16 & - & - & 22 & - & - & 12 & 28 & [125] \\
\hline $\begin{array}{l}\text { Monocalcium } \\
\text { chlorophosphate }\end{array}$ & Denmark & 34 & - & 1 & $<0.013$ & $<0.2$ & 2.8 & 0.084 & 0.94 & 1.1 & 5.4 & [82] \\
\hline Commercial fertilizer & - & 51.0 & $46.9^{\mathrm{b}}$ & 7.5 & 4.2 & 121.2 & 13 & - & 41.2 & 3.1 & 182.9 & [155] \\
\hline \multirow{6}{*}{$\begin{array}{l}\text { Fertilizer ordinance by } \\
\text { country }\end{array}$} & Germany & - & - & 40 & $1.5^{\mathrm{d}}$ & 300 & 70 & 1 & 80 & 150 & 1,000 & {$[6,19]$} \\
\hline & Poland & - & - & 50 & 50 & - & - & 2 & - & 140 & - & [48] \\
\hline & Austria & - & - & - & 15 & 667 & 778 & 1 & - & 100 & 3,333 & [55] \\
\hline & Switzerland & - & - & - & 3 & 200 & 400 & 3 & 50 & 200 & 1,300 & {$[19,55]$} \\
\hline & Korea & - & - & 45 & 5 & 250 & 400 & - & 45 & 130 & 1,000 & [53] \\
\hline & China & - & - & - & 10 & 500 & - & 5 & - & 150 & - & [55] \\
\hline
\end{tabular}

a Ref. = references; ND = non-detected; “-” donates "not available”; “*” donates "studies using sequential extraction”.

b Ammonium citrate soluble.

c Citrate acid soluble.

d Or $50 \mathrm{mg} / \mathrm{kg} \mathrm{P}_{2} \mathrm{O}_{5}$ when $\mathrm{P}_{2} \mathrm{O}_{5}>5 \%$.

efficiency from ash was relatively low $(\leq 62 \%)$, due to the low P extraction efficiency $(\leq 73 \%)$ and precipitation efficiency $(\leq 85 \%)$, which can be further improved. The process also requires a high temperature $\left(95{ }^{\circ} \mathrm{C}\right)$ to evaporate water to induce the crystallization of $\mathrm{CaClH}_{2} \mathrm{PO}_{4} \cdot \mathrm{H}_{2} \mathrm{O}$, with estimated chemical and energy costs of US\$ 5.8 / $\mathrm{kg}$ P. The recovered product can be further calcinated to produce $\mathrm{CaHPO}_{4}$ for market interests [82]. However, this approach can hardly be applied unless the following drawbacks are addressed: 1) The total P recovery needs to be improved by process optimization; 2 ) the overall cost is far beyond the market value of Ca-P (up to US\$ $2 / \mathrm{kg} \mathrm{P}$ ) in Table 4; and, 3) the requirements of equipment quality and capital costs are much higher than typical recovery processes due to more corrosive conditions (high temperature and extremely low $\mathrm{pH}$ ).

\subsection{Vivianite}

$\mathrm{P}$ recovery as vivianite has become popular particularly from ironrich municipal sludge, where vivianite accounts for a major $\mathrm{P}$ fraction (up to 90\%) [149]. One significant advantage of vivianite is its foreseeable economic value with a much higher market price than other recovered products as shown in Table 4. Vivianite has also exhibited a great potential to serve as Fe and P fertilizers simultaneously to prevent Fe chlorosis and enhance crop yield as demonstrated by several field studies $[150,151]$. Lab-scale studies indicated that vivianite crystallization for $\mathrm{P}$ recovery was feasible under complex environment, with enhanced precipitation efficiency (nearly 100\%) from pH 5 to 8 or Fe:P ratio from 1 to 2 and high purity (e.g., $82 \%$ vivianite and $10 \%$ silica), whereas the effect of temperature was found insignificant $\left(25-55{ }^{\circ} \mathrm{C}\right)$ $[139,152,153]$. To the best of knowledge, there is a lack of studies about recovering $\mathrm{P}$ as vivianite from sludge-derived ash and hydrochar. This is possibly due to several challenges: 1) Addition of expensive iron(II) salts; 2) prerequisite of reductive and anoxic conditions for recovery; 3 ) purity demand of product: Vivianite is only metastable at ambient conditions, while impurities may cause full oxidization within 2 days [1]. To further develop this novel and profitable precipitation approach, future research should focus on optimizing operational parameters, reasonable purification procedures, potential risks of contaminants in recovered products, as well as comprehensive life cycle and economic assessment.

\subsection{Contaminants in recovered fertilizers}

Studies have shown that $\mathrm{P}$ in recovered Ca-P and struvite has a high plant availability ( $>89 \%$ of total P) as shown in Table 7 . However, along with $P$ recovery from sludge-derived ash and hydrochar (particularly by acidic extraction), concerning contaminants (mainly heavy metals) could also be captured in the final products, which can limit their application to agriculture. Without any pre-treatment or purification, the recovered fertilizer may contain concerning amounts of heavy metals (e.g., $\mathrm{Cd}, \mathrm{Cu}$, and $\mathrm{Zn}$ ) $[6,48]$. Even purified by a significant amount of CER $(2 \mathrm{~kg} / \mathrm{kg}$ ash) prior to precipitation, a considerable quantity of $\mathrm{Cu}$ and $\mathrm{Zn}$ can still be present [55]. A life cycle assessment of

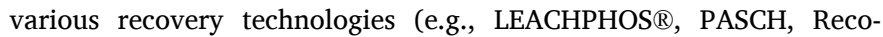
Phos ${ }^{\circledR}$, Fertilizer Industry, and EcoPhos ${ }^{\circledR}$ ) suggested that the decontamination of heavy metals caused higher environmental impacts (e.g., emissions and energy demand) [154]. A techno-economic and environmental assessment revealed that $\mathrm{P}$ recovery costs were highly dependent on the purity requirements of recovered products, with an estimated additional cost of US\$ 1.2-2.4 per capita per year associated with significant depollution of heavy metals [16]. Several recently developed sequential extraction methods (see Section 4.3) provide promising alternatives for $\mathrm{P}$ recovery and depollution with simple procedures $[53,62,106,135]$. Their recovered products showed limited heavy metals contents, all below most regulatory fertilizer standards (Table 7).

Regarding sludge-derived hydrochar, there is a lack of information about heavy metals contents in its recovered fertilizers. Thus, the necessity of purification during recovery remains unknown. Unlike fully combusted ash, hydrochar derived from municipal sludge has been found to contain various persistent organic pollutants, such as polycyclic aromatic hydrocarbons, polychlorinated biphenyls, polychlorinated dibenzo-dioxins/-furans, pharmaceuticals, personal care products [43,156-159]. Organic micropollutants (e.g., benzotriazole and carbamazepine) have been identified in struvite directly recovered from municipal sludge [155]. Therefore, the transformation and risks of organic contaminants should also be investigated during the P recovery from hydrochar. Studies reporting on optimum HTL temperatures/ pressures to destroy trace contaminants of emerging concern in HTL aqueous and hydrochar from municipal sludge are lacking. Due to limited studies, the impacts of organic pollutants are not discussed in this review. Potential contamination from pathogens is not a concern as 
all microorganisms shall be eliminated because of the thermochemical

processes.

\section{Conclusions and prospects}

$P$ recovery and recycling are necessary to mitigate environmental challenges (eutrophication), improve water quality, address P scarcity, and sustain local food production in a circular economy approach. Ash and hydrochar from municipal sludge thermal treatment are promising sources for $\mathrm{P}$ recovery. Wet chemical extraction and precipitation processes are technically feasible, cost-effective, and reliable for P recovery from ash and hydrochar. However, high concentrations of heavy metals (e.g., up to $10,000 \mathrm{mg} / \mathrm{kg}$ of $\mathrm{Cu}$ ) in ash and hydrochar could complicate the recovery processes. The contents and species of $\mathrm{P}$ and co-existing metals ( $\mathrm{Al}, \mathrm{Ca}, \mathrm{Fe}$, and $\mathrm{Mg}$ especially) also affect the extraction step and quality of recovered products. This review highlighted the key features, challenges, and recent advances of $P$ recovery from sludgederived ash and hydrochar, and advantages and limitations of different processes are discussed. The major findings of this review summarized below will contribute to the improvement of $\mathrm{P}$ recovery from waste streams.

- Considering the largely varied contents of sludge-derived ash (13.5-25.7\% $\mathrm{P}_{2} \mathrm{O}_{5}, 5.6-21.1 \% \mathrm{Al}_{2} \mathrm{O}_{3}, 8.4-20.8 \% \mathrm{CaO}$, and 4.3-20\% $\left.\mathrm{Fe}_{2} \mathrm{O}_{3}\right)$ and hydrochar $\left(5.2-13.6 \% \mathrm{P}_{2} \mathrm{O}_{5}, 0.6-17 \% \mathrm{Al}_{2} \mathrm{O}_{3}, 1.4-9.2 \%\right.$ $\mathrm{CaO}$, and 1.8-13.7\% $\mathrm{Fe}_{2} \mathrm{O}_{3}$ ), establishing regional-specific $\mathrm{P}$ recovery process is necessary to ensure stable $\mathrm{P}$ recovery performance.

- For wet-chemical processes, extraction is the critical first step to maximize $P$ recovery and minimize potential pollution by optimizing operational parameters. Minimal process inputs (e.g., water, chemicals, and energy) should be targeted to improve process sustainability.

- In terms of process applicability, acidic extraction $(\mathrm{pH}<2)$ is suitable for all types of ash and hydrochar and could achieve nearly $100 \%$ P extraction, while depollution step is often necessary due to the significant heavy metals contamination (e.g., As, $\mathrm{Cd}, \mathrm{Cu}, \mathrm{Pb}$, and $\mathrm{Zn})$. Pretreatment with chelating agents is not cost-effective for $\mathrm{P}$ recovery and heavy metals removal. Alkaline extraction $(\mathrm{pH} \geq 12)$ is only appropriate to feedstocks with high contents of NAIP, but it avoids the contamination of heavy metals ( $<1 \%$ leachable). The recent advances of sequential extraction approaches allow them to be applicable to all feedstocks, with desirable P recovery (up to 91\%) and limited heavy metals. Ideally, after leaching heavy metals from ash and hydrochar, the remaining solid residues could be landapplied, and heavy metals in leachates could be precipitated and recovered, thus achieving zero waste. However, the new processes are lacking economic and pilot/full-scale assessments.

- Struvite and Ca-P are mostly precipitated from P-rich extracts to produce fertilizers for their high plant-availability ( $>89 \%$ of total P), while optimization is needed for the highest cost-efficiency. Vivianite represents a highly profitable recoverable product, which demands detailed studies to demonstrate its applicability to $\mathrm{P}$ recovery from sludge-derived ash and hydrochar. Metal salts (e.g., $\mathrm{MgCl}_{2}$, $\mathrm{CaCl}_{2}$, and $\mathrm{FeCl}_{2}$ ) are efficient for precipitation, but they are much more expensive than oxygen-bearing minerals (e.g., $\mathrm{MgO}$ and $\mathrm{CaO}$ ). The combined use of mineral salts and oxides could balance the chemical cost and recovery efficiency. Possible interference by $\mathrm{Al}^{3+}$ and $\mathrm{Fe}^{3+}$ cations should be avoided during precipitation to assure the product quality.

- Without proper purification steps, recovered $\mathrm{P}$ fertilizers from sludge-derived ash could contain concerning amounts of heavy metals (e.g., $\mathrm{Cd}, \mathrm{Cu}$, and $\mathrm{Zn}$ ), while methods using sequential extraction can fulfill the safe metals concentrations of most fertilizer ordinances. However, there is a lack of studies about the potential risks associated with heavy metals and organic contaminants of recovered products from hydrochar.
HTL has been found the most promising technology in handling municipal sludge owing to the potential for commercialization and netpositive energy recovery. It represents a justifiable operation for sludge treatment, as carbon is maximized to biocrude and $\mathrm{P}$ is enriched in hydrochar to allow its recovery. $\mathrm{P}$ recovery from sludge-derived hydrochar is a critical and necessary step for promoting the implementation of full-scale HTL at wastewater treatment plants. This review underscores the following challenges and prospects of building towards a sustainable waste management system: Integrated wastewater treatment, HTL (energy recovery), and nutrient recovery.

- Feedstock-specific processes using low-cost (e.g., $\mathrm{H}_{2} \mathrm{SO}_{4}$ ) and effective (e.g., oxalic acid) extractants should be developed for P extraction. The optimal ratios of combined acids for extraction can be investigated to explore any possible synergistic effects. An alternative technically and economically feasible purification process (e.g., sequential extraction and cost-effective adsorption) is encouraged to address the contamination issue in acidic extraction.

- Sequential extraction processes (A-E) are promising to extract most $\mathrm{P}$ with limited heavy metals, preventing additional costs for purification. However, the extraction efficiency and applicability can be further improved to accommodate hydrochar with various compositions. For Processes $\mathrm{A}$ and $\mathrm{B}$, the requirements on hydrochar compositions (e.g., Al contents) should be identified for the maximum $\mathrm{P}$ extraction efficiency. For Process $\mathrm{C}$, raising the $\mathrm{pH}$ from 3 to 5 during the pre-precipitation step could enhance the overall $\mathrm{P}$ extraction efficiency, and removing the step of cation exchange without lowering the product purity is necessary to reduce the cost and complexity. For Process D, cost-effective chelating agents (e.g., optimal combination of different extractants) should be discovered to reduce $\mathrm{P}$ loss, enhance heavy metals removal, and minimize the cost. For Process E, improving the adsorption capacity and examining the reusability of activated alumina are needed for better costeffectiveness.

- The plant availability of $\mathrm{P}$ in recovered fertilizers through agronomic evaluation by pot or field trials is beneficial to their agricultural application and public acceptance. The fate and transport modeling of heavy metals and organic pollutants in recovered products should be comprehensively examined for the determination of ecological risk assessment. Detailed techno-economic and environmental assessments focusing on various wet-chemical approaches for P recovery are essential to identify the advantages and weaknesses of each process and guide and facilitate their improvement.

- Discovering the ultimate disposal/utilization routes of hydrochar residue after recovery of $\mathrm{P}$ and heavy metals, recycling, and disposal of post-recovery process water can facilitate the complete cycle of sustainable waste management. To determine the usability of postrecovery hydrochar, the following examinations can be considered: Agricultural application as soil amendment, adsorption as a direct adsorbent or activated hydrochar, and heterogeneous catalysis as magnetic hydrochar.

- The optimization of process design and phase separation of HTL is necessary to allow most energy in biocrude and $\mathrm{P}$ in hydrochar. $\mathrm{P}$ recovery methods should be developed specifically based on the optimized HTL treatment for maximum energy recovery. The life cycle assessment and cost analysis of HTL combined with nutrient recovery can illustrate the environmental and economic benefits of upgrading wastewater treatment plants into wastewater biorefineries.

- Legislation is a key driver in promoting $\mathrm{P}$ recovery and recycling. Environmental regulations of stringent discharge limit and mandatory $\mathrm{P}$ removal could concentrate $\mathrm{P}$ into the sludge stream and its derivative hydrochar. Policies of facilitating the use of recovered fertilizers, such as tax-free and renewable resources credits, could stimulate the development of sustainable and innovative $P$ recovery technologies and their full-scale applications. 


\section{Declaration of Competing Interest}

The authors declare that they have no known competing financial interests or personal relationships that could have appeared to influence the work reported in this paper.

\section{Acknowledgments}

This research was funded by the Natural Sciences and Engineering Research Council of Canada (NSERC) and Metro Vancouver Industrial Research Chair Program in Advanced Resource Recovery from Wastewater (IRCPJ 548816-18). The authors would also like to thank the anonymous reviewers for their insightful comments and suggestions, which greatly helped the improvement of the manuscript.

\section{References}

[1] Y. Wu, J. Luo, Q. Zhang, M. Aleem, F. Fang, Z. Xue, J. Cao, Potentials and challenges of phosphorus recovery as vivianite from wastewater: A review, Chemosphere. 226 (2019) 246-258, https://doi.org/10.1016/j. chemosphere.2019.03.138.

[2] L. Peng, H. Dai, Y. Wu, Y. Peng, X. Lu, A comprehensive review of phosphorus recovery from wastewater by crystallization processes, Chemosphere. 197 (2018) 768-781, https://doi.org/10.1016/j.chemosphere.2018.01.098.

[3] E. Hou, Y. Luo, Y. Kuang, C. Chen, X. Lu, L. Jiang, X. Luo, D. Wen, Global metaanalysis shows pervasive phosphorus limitation of aboveground plant production in natural terrestrial ecosystems, Nat. Commun. 11 (2020) 1-9, https://doi.org/ 10.1038/s41467-020-14492-w.

[4] H. Kroiss, H. Rechberger, L. Egle, Phosphorus in Water Quality and Waste Management, in: Integr. Waste Manag. - Vol. II, InTech, 2011: pp. 181-214. doi: $10.5772 / 18482$.

[5] B.K. Mayer, L.A. Baker, T.H. Boyer, P. Drechsel, M. Gifford, M.A. Hanjra, P. Parameswaran, J. Stoltzfus, P. Westerhoff, B.E. Rittmann, Total Value of Phosphorus Recovery, Environ. Sci. Technol. 50 (13) (2016) 6606-6620, https:// doi.org/10.1021/acs.est.6b0123910.1021/acs.est.6b01239.s001.

[6] H. Weigand, M. Bertau, W. Hübner, F. Bohndick, A. Bruckert, RecoPhos: Fullscale fertilizer production from sewage sludge ash, Waste Manag. 33 (3) (2013) 540-544, https://doi.org/10.1016/j.wasman.2012.07.009.

[7] United States Geological Survey, Mineral Commodity Summaries: Phosphate Rock (2020), https://doi.org/10.3133/mcs2020.

[8] United States Geological Survey, Mineral Commodity Summaries: Phosphate Rock, 2009. https://s3-us-west-2.amazonaws.com/prd-wret/assets/palladium/ production/mineral-pubs/phosphate-rock/mcs-2009-phosp.pdf.

[9] R. Huang, C.i. Fang, X. Lu, R. Jiang, Y. Tang, Transformation of phosphorus during (hydro)thermal treatments of solid Biowastes: Reaction mechanisms and implications for P reclamation and recycling, Environ. Sci. Technol. 51 (18) (2017) 10284-10298, https://doi.org/10.1021/acs.est.7b0201110.1021/acs. est.7b02011.s001.

[10] L. Wei, F. Zhu, Q. Li, C. Xue, X. Xia, H. Yu, Q. Zhao, J. Jiang, S. Bai, Development, current state and future trends of sludge management in China: Based on exploratory data and CO2-equivaient emissions analysis, Environ. Int. 144 (2020) 106093, https://doi.org/10.1016/j.envint.2020.106093.

[11] Eurostat, Sewage sludge production and disposal from urban wastewater (in dry substance (d.s)), Eur. Comm. (2020). https://ec.europa.eu/eurostat/ databrowser/product/view/ENV_WW_SPD (accessed December 23, 2020)

[12] J. Mateo-Sagasta, L. Raschid-Sally, A. Thebo, Global wastewater and sludge production, treatment and use, in: Wastewater Econ. Asset an Urban. World, Springer Netherlands, 2015: pp. 15-38. doi:10.1007/978-94-017-9545-6_2.

[13] V. Singh, H.C. Phuleria, M.K. Chandel, Estimation of energy recovery potential of sewage sludge in India: Waste to watt approach, J. Clean. Prod. 276 (2020) 122538, https://doi.org/10.1016/j.jclepro.2020.122538.

[14] P.A. Marrone, D.C. Elliott, J.M. Billing, R.T. Hallen, T.R. Hart, P. Kadota, J. C. Moeller, M.A. Randel, A.J. Schmidt, Bench-scale evaluation of hydrothermal processing technology for conversion of wastewater solids to fuels, Water Environ. Res. 90 (4) (2018) 329-342, https://doi.org/10.2175/ $106143017 X 15131012152861$.

[15] Y. Shi, G. Luo, Y. Rao, H. Chen, S. Zhang, Hydrothermal conversion of dewatered sewage sludge: Focusing on the transformation mechanism and recovery of phosphorus, Chemosphere. 228 (2019) 619-628, https://doi.org/10.1016/j. chemosphere.2019.04.109.

[16] L. Egle, H. Rechberger, J. Krampe, M. Zessner, Phosphorus recovery from municipal wastewater: An integrated comparative technological, environmental and economic assessment of P recovery technologies, Sci. Total Environ. 571 (2016) 522-542, https://doi.org/10.1016/j.scitotenv.2016.07.019.

[17] G. Kor-Bicakci, C. Eskicioglu, Recent developments on thermal municipal sludge pretreatment technologies for enhanced anaerobic digestion, Renew. Sustain. Energy Rev. 110 (2019) 423-443, https://doi.org/10.1016/j.rser.2019.05.002.

[18] S. Donatello, C.R. Cheeseman, Recycling and recovery routes for incinerated sewage sludge ash (ISSA): A review, Waste Manag. 33 (11) (2013) 2328-2340, https://doi.org/10.1016/j.wasman.2013.05.024.
[19] L. Fang, Q. Wang, J. Li, C.S. Poon, C.R. Cheeseman, S. Donatello, D.C.W. Tsang, Feasibility of wet-extraction of phosphorus from incinerated sewage sludge ash (ISSA) for phosphate fertilizer production: A critical review, Crit. Rev. Environ. Sci. Technol. (2020) 1-33, https://doi.org/10.1080/10643389.2020.1740545.

[20] J. Moreno, J.J. Espada, Chapter 10 Environmental and techno-economic assessment of thermochemical treatment systems for sludge, in: Wastewater Treat. Residues as Resour. Biorefinery Prod. Biofuels, Elsevier, 2019: pp. 201-223. doi:10.1016/B978-0-12-816204-0.00010-2.

[21] A.R. Jupp, S. Beijer, G.C. Narain, W. Schipper, J.C. Slootweg, Phosphorus recovery and recycling - closing the loop, Chem. Soc. Rev. 50 (1) (2021) 87-101, https://doi.org/10.1039/D0CS01150A.

[22] E. Ovsyannikova, A. Kruse, G.C. Becker, Feedstock-dependent phosphate recovery in a pilot-scale hydrothermal liquefaction bio-crude production, Energies. 13 (2020) 379, https://doi.org/10.3390/en13020379.

[23] A.A. Shah, S.S. Toor, F. Conti, A.H. Nielsen, L.A. Rosendahl, Hydrothermal liquefaction of high ash containing sewage sludge at sub and supercritical conditions, Biomass and Bioenergy. 135 (2020) 105504, https://doi.org/ 10.1016/j.biombioe.2020.105504.

[24] M. Kacprzak, E. Neczaj, K. Fijałkowski, A. Grobelak, A. Grosser, M. Worwag, A. Rorat, H. Brattebo, A. Almås, B.R. Singh, Sewage sludge disposal strategies for sustainable development, Environ. Res. 156 (2017) 39-46, https://doi.org/ 10.1016/j.envres.2017.03.010.

[25] A. Murray, A. Horvath, K.L. Nelson, Hybrid life-cycle environmental and cost inventory of sewage sludge treatment and end-use scenarios: A case study from China, Environ. Sci. Technol. 42 (9) (2008) 3163-3169, https://doi.org/ 10.1021/es702256w.

[26] D. Đurđević, P. Blecich, Ž. Jurić, Energy Recovery from Sewage Sludge: The Case Study of Croatia, Energies. 12 (2019) 1927, https://doi.org/10.3390/ en12101927.

[27] T.E. Seiple, R.L. Skaggs, L. Fillmore, A.M. Coleman, Municipal wastewater sludge as a renewable, cost-effective feedstock for transportation biofuels using hydrothermal liquefaction, J. Environ. Manage. 270 (2020) 110852, https://doi. org/10.1016/j.jenvman.2020.110852.

[28] F. Conti, S.S. Toor, T.H. Pedersen, T.H. Seehar, A.H. Nielsen, L.A. Rosendahl, Valorization of animal and human wastes through hydrothermal liquefaction for biocrude production and simultaneous recovery of nutrients, Energy Convers. Manag. 216 (2020) 112925, https://doi.org/10.1016/j.enconman.2020.112925.

[29] K. Anastasakis, P. Biller, R.B. Madsen, M. Glasius, I. Johannsen, Continuous hydrothermal liquefaction of biomass in a novel pilot plant with heat recovery and hydraulic oscillation, Energies. 11 (2018) 1-23, https://doi.org/10.3390/ en11102695.

[30] I.A. Basar, H. Liu, H. Carrere, E. Trably, C. Eskicioglu, A review on key design and operational parameters to optimize and develop hydrothermal liquefaction of biomass for biorefinery applications, Green Chem. 23 (4) (2021) 1404-1446, https://doi.org/10.1039/D0GC04092D.

[31] L. Luyckx, S. Geerts, J.o. Van Caneghem, Closing the phosphorus cycle: Multicriteria techno-economic optimization of phosphorus extraction from wastewater treatment sludge ash, Sci. Total Environ. 713 (2020) 135543, https://doi.org/ 10.1016/j.scitotenv.2019.135543.

[32] L. Wang, A. Li, Y. Chang, Hydrothermal treatment coupled with mechanical expression at increased temperature for excess sludge dewatering: Heavy metals, volatile organic compounds and combustion characteristics of hydrochar, Chem. Eng. J. 297 (2016) 1-10, https://doi.org/10.1016/j.cej.2016.03.131.

[33] X. Meng, Q. Huang, J. Xu, H. Gao, J. Yan, A review of phosphorus recovery from different thermal treatment products of sewage sludge, Waste Dispos. Sustain. Energy. 1 (2) (2019) 99-115, https://doi.org/10.1007/s42768-019-00007-X.

[34] Y.-H. Fei, D. Zhao, Y.e. Liu, W. Zhang, Y.-Y. Tang, X. Huang, Q. Wu, Y.-X. Wang, T. Xiao, C. Liu, Feasibility of sewage sludge derived hydrochars for agricultural application: Nutrients $(\mathrm{N}, \mathrm{P}, \mathrm{K})$ and potentially toxic elements $(\mathrm{Zn}, \mathrm{Cu}, \mathrm{Pb}, \mathrm{Ni}$, Cd), Chemosphere. 236 (2019) 124841, https://doi.org/10.1016/j. chemosphere.2019.124841.

[35] E. Ovsyannikova, P.J. Arauzo, G. Becker, A. Kruse, Experimental and thermodynamic studies of phosphate behavior during the hydrothermal carbonization of sewage sludge, Sci. Total Environ. 692 (2019) 147-156, https:// doi.org/10.1016/j.scitotenv.2019.07.217.

[36] B. Li, H.M. Huang, I. Boiarkina, W. Yu, Y.F. Huang, G.Q. Wang, B.R. Young, Phosphorus recovery through struvite crystallisation: Recent developments in the understanding of operational factors, J. Environ. Manage. 248 (2019) 109254 , https://doi.org/10.1016/j.jenvman.2019.07.025.

[37] B. Tansel, G. Lunn, O. Monje, Struvite formation and decomposition characteristics for ammonia and phosphorus recovery: A review of magnesiumammonia-phosphate interactions, Chemosphere. 194 (2018) 504-514, https:// doi.org/10.1016/j.chemosphere.2017.12.004.

[38] S. Kataki, H. West, M. Clarke, D.C. Baruah, Phosphorus recovery as struvite: Recent concerns for use of seed, alternative Mg source, nitrogen conservation and fertilizer potential, Resour. Conserv. Recycl. 107 (2016) 142-156, https://doi. org/10.1016/j.resconrec.2015.12.009.

[39] R. Kumar, P. Pal, Assessing the feasibility of N and P recovery by struvite precipitation from nutrient-rich wastewater: a review, Environ. Sci. Pollut. Res. 22 (22) (2015) 17453-17464, https://doi.org/10.1007/s11356-015-5450-2.

[40] B. Li, I. Boiarkina, W. Yu, H.M. Huang, T. Munir, G.Q. Wang, B.R. Young, Phosphorous recovery through struvite crystallization: Challenges for future design, Sci. Total Environ. 648 (2019) 1244-1256, https://doi.org/10.1016/j. scitotenv.2018.07.166

[41] E. Desmidt, K. Ghyselbrecht, Y. Zhang, L. Pinoy, B. Van der Bruggen, W. Verstraete, K. Rabaey, B. Meesschaert, Global phosphorus scarcity and full- 
scale P-recovery techniques: A review, Crit. Rev. Environ. Sci. Technol. 45 (4) (2015) 336-384, https://doi.org/10.1080/10643389.2013.866531.

[42] M. Van de Velden, R. Dewil, J. Baeyens, L. Josson, P. Lanssens, The distribution of heavy metals during fluidized bed combustion of sludge (FBSC), J. Hazard. Mater 151 (1) (2008) 96-102, https://doi.org/10.1016/j.jhazmat.2007.05.056.

[43] L.B. Silva Thomsen, P.N. Carvalho, J.S. dos Passos, K. Anastasakis, K. Bester, P. Biller, Hydrothermal liquefaction of sewage sludge; energy considerations and fate of micropollutants during pilot scale processing, Water Res. 183 (2020) 116101, https://doi.org/10.1016/j.watres.2020.116101.

[44] T.X. Do, R. Mujahid, H.S. Lim, J.-K. Kim, Y.-I. Lim, J. Kim, Techno-economic analysis of bio heavy-oil production from sewage sludge using supercritical and subcritical water, Renew. Energy. 151 (2020) 30-42, https://doi.org/10.1016/j renene.2019.10.138.

[45] U. Ekpo, A.B. Ross, M.A. Camargo-Valero, P.T. Williams, A comparison of product yields and inorganic content in process streams following thermal hydrolysis and hydrothermal processing of microalgae, manure and digestate, Bioresour. Technol. 200 (2016) 951-960, https://doi.org/10.1016/j.biortech.2015.11.018.

[46] C. He, K.e. Wang, A. Giannis, Y. Yang, J.-Y. Wang, Products evolution during hydrothermal conversion of dewatered sewage sludge in sub- and near-critical water: Effects of reaction conditions and calcium oxide additive, Int. J. Hydrogen Energy. 40 (17) (2015) 5776-5787, https://doi.org/10.1016/j ijhydene.2015.03.006.

[47] J.T. Bunce, E. Ndam, I.D. Ofiteru, A. Moore, D.W. Graham, A review of phosphorus removal technologies and their applicability to small-scale domestic wastewater treatment systems, Front. Environ. Sci. 6 (2018) 8, https://doi.org/ 10.3389/fenvs. 2018.00008.

[48] K. Gorazda, B. Tarko, Z. Wzorek, H. Kominko, A.K. Nowak, J. Kulczycka, A. Henclik, M. Smol, Fertilisers production from ashes after sewage sludge combustion - A strategy towards sustainable development, Environ. Res. 154 (2017) 171-180, https://doi.org/10.1016/j.envres.2017.01.002.

[49] R. Li, Z. Zhang, Y. Li, W. Teng, W. Wang, T. Yang, Transformation of apatite phosphorus and non-apatite inorganic phosphorus during incineration of sewage sludge, Chemosphere. 141 (2015) 57-61, https://doi.org/10.1016/j. chemosphere.2015.05.094.

[50] R. Li, W. Zhao, Y. Li, W. Wang, X. Zhu, Heavy metal removal and speciation transformation through the calcination treatment of phosphorus-enriched sewage sludge ash, J. Hazard. Mater. 283 (2015) 423-431, https://doi.org/10.1016/j. jhazmat.2014.09.052.

[51] B.H. Lim, D.J. Kim, Selective acidic elution of Ca from sewage sludge ash for phosphorus recovery under pH control, J. Ind. Eng. Chem. 46 (2017) 62-67, https://doi.org/10.1016/j.jiec.2016.10.016.

[52] S. Petzet, B. Peplinski, P. Cornel, On wet chemical phosphorus recovery from sewage sludge ash by acidic or alkaline leaching and an optimized combination of both, Water Res. 46 (12) (2012) 3769-3780, https://doi.org/10.1016/j. watres.2012.03.068.

[53] M.M.T. Zin, D.J. Kim, Struvite production from food processing wastewater and incinerated sewage sludge ash as an alternative $\mathrm{N}$ and P source: Optimization of multiple resources recovery by response surface methodology, Process Saf. Environ. Prot. 126 (2019) 242-249, https://doi.org/10.1016/j. psep.2019.04.018.

[54] T.P. Thomsen, Z. Sárossy, J. Ahrenfeldt, U.B. Henriksen, F.J. Frandsen, D. S. Müller-Stöver, Changes imposed by pyrolysis, thermal gasification and incineration on composition and phosphorus fertilizer quality of municipal sewage sludge, J. Environ. Manage. 198 (2017) 308-318, https://doi.org/ 10.1016/j.jenvman.2017.04.072.

[55] H. Xu, P. He, W. Gu, G. Wang, L. Shao, Recovery of phosphorus as struvite from sewage sludge ash, J. Environ. Sci. 24 (8) (2012) 1533-1538, https://doi.org/ 10.1016/S1001-0742(11)60969-8.

[56] M. Takahashi, S. Kato, H. Shima, E. Sarai, T. Ichioka, S. Hatyakawa, H. Miyajiri, Technology for recovering phosphorus from incinerated wastewater treatment sludge, Chemosphere. 44 (1) (2001) 23-29, https://doi.org/10.1016/S00456535(00)00380-5.

[57] C. Vogel, M. Radtke, U. Reinholz, F. Schäfers, C. Adam, Chemical state of chromium, sulfur, and iron in sewage sludge ash based phosphorus fertilizers, ACS Sustain. Chem. Eng. 3 (10) (2015) 2376-2380, https://doi.org/10.1021/ acssuschemeng.5b00678.

[58] M. Takaoka, T. Yamamoto, S. Fujiwara, K. Oshita, N. Takeda, T. Tanaka, T. Uruga, Chemical states of trace elements in sewage sludge incineration ash by using x-ray absorption fine structure, Water Sci. Technol. 57 (2008) 411-417, https://doi.org/10.2166/wst.2008.025.

[59] S. Donatello, M. Tyrer, C.R. Cheeseman, EU landfill waste acceptance criteria and EU Hazardous Waste Directive compliance testing of incinerated sewage sludge ash, Waste Manag. 30 (1) (2010) 63-71, https://doi.org/10.1016/j. wasman.2009.09.028.

[60] C.R. Cheeseman, G.S. Virdi, Properties and microstructure of lightweight aggregate produced from sintered sewage sludge ash, Resour. Conserv. Recycl. 45 (1) (2005) 18-30, https://doi.org/10.1016/j.resconrec.2004.12.006.

[61] M. Franz, Phosphate fertilizer from sewage sludge ash (SSA), Waste Manag. 28 (10) (2008) 1809-1818, https://doi.org/10.1016/j.wasman.2007.08.011.

[62] S. Liang, H. Chen, X. Zeng, Z. Li, W. Yu, K. Xiao, J. Hu, H. Hou, B. Liu, S. Tao, J. Yang, A comparison between sulfuric acid and oxalic acid leaching with subsequent purification and precipitation for phosphorus recovery from sewage sludge incineration ash, Water Res. 159 (2019) 242-251, https://doi.org/ 10.1016/j.watres.2019.05.022.
[63] S. Donatello, D. Tong, C.R. Cheeseman, Production of technical grade phosphoric acid from incinerator sewage sludge ash (ISSA), Waste Manag. 30 (8-9) (2010) 1634-1642, https://doi.org/10.1016/j.wasman.2010.04.009.

[64] L. Fang, J. Li, M.Z. Guo, C.R. Cheeseman, D.C.W. Tsang, S. Donatello, C.S. Poon, Phosphorus recovery and leaching of trace elements from incinerated sewage sludge ash (ISSA), Chemosphere. 193 (2018) 278-287, https://doi.org/10.1016/ j.chemosphere.2017.11.023.

[65] H. Herzel, O. Krüger, L. Hermann, C. Adam, Sewage sludge ash - A promising secondary phosphorus source for fertilizer production, Sci. Total Environ. 542 (2016) 1136-1143, https://doi.org/10.1016/j.scitotenv.2015.08.059.

[66] R. Kleemann, J. Chenoweth, R. Clift, S. Morse, P. Pearce, D. Saroj, Comparison of phosphorus recovery from incinerated sewage sludge ash (ISSA) and pyrolysed sewage sludge char (PSSC), Waste Manag. 60 (2017) 201-210, https://doi.org/ 10.1016/j.wasman.2016.10.055.

[67] M. Lee, D.J. Kim, Identification of phosphorus forms in sewage sludge ash during acid pre-treatment for phosphorus recovery by chemical fractionation and spectroscopy, J. Ind. Eng. Chem. 51 (2017) 64-70, https://doi.org/10.1016/j. jiec.2017.02.013.

[68] S. Zhang, Q. Du, K. Cheng, M. Antonietti, F. Yang, Efficient phosphorus recycling and heavy metal removal from wastewater sludge by a novel hydrothermal humification-technique, Chem. Eng. J. 394 (2020) 124832, https://doi.org/ 10.1016/j.cej.2020.124832.

[69] J.-H. ZHANG, Q.-M. LIN, X.-R. ZHAO, The hydrochar characters of municipal sewage sludge under different hydrothermal temperatures and durations, J. Integr. Agric. 13 (3) (2014) 471-482, https://doi.org/10.1016/S2095-3119 (13)60702-9.

[70] X. Zhuang, Y. Song, H. Zhan, X. Yin, C. Wu, Influences of microstructural alternations and inorganic catalysis on the thermochemical conversion of biowaste-derived hydrochar, Fuel Process. Technol. 199 (2020) 106304, https:// doi.org/10.1016/j.fuproc.2019.106304.

[71] Y. Feng, K. Ma, T. Yu, S. Bai, D.i. Pei, T. Bai, Q. Zhang, L. Yin, Y. Hu, D. Chen, Phosphorus transformation in hydrothermal pretreatment and steam gasification of sewage sludge, Energy and Fuels. 32 (8) (2018) 8545-8551, https://doi.org/ 10.1021/acs.energyfuels.8b01860.

[72] X.P. Zhang, C. Zhang, X. Li, S.H. Yu, P. Tan, Q.Y. Fang, G. Chen, A two-step process for sewage sludge treatment: Hydrothermal treatment of sludge and catalytic hydrothermal gasification of its derived liquid, Fuel Process. Technol. 180 (2018) 67-74, https://doi.org/10.1016/j.fuproc.2018.08.012.

[73] J.D. Marin-Batista, A.F. Mohedano, J.J. Rodríguez, M.A. de la Rubia, Energy and phosphorous recovery through hydrothermal carbonization of digested sewage sludge, Waste Manag. 105 (2020) 566-574, https://doi.org/10.1016/j wasman.2020.03.004.

[74] M. Breulmann, M. van Afferden, R.A. Müller, E. Schulz, C. Fühner, Process conditions of pyrolysis and hydrothermal carbonization affect the potential of sewage sludge for soil carbon sequestration and amelioration, J. Anal. Appl. Pyrolysis. 124 (2017) 256-265, https://doi.org/10.1016/j.jaap.2017.01.026.

[75] S. Wang, H. Persson, W. Yang, P.G. Jönsson, Pyrolysis study of hydrotherma carbonization-treated digested sewage sludge using a Py-GC/MS and a benchscale pyrolyzer, Fuel. 262 (2020) 116335, https://doi.org/10.1016/j. fuel.2019.116335.

[76] R. Li, W. Teng, Y. Li, W. Wang, R. Cui, T. Yang, Potential recovery of phosphorus during the fluidized bed incineration of sewage sludge, J. Clean. Prod. 140 (2017) 964-970, https://doi.org/10.1016/j.jclepro.2016.06.177.

[77] J. Ma, M. Chen, T. Yang, Z. Liu, W. Jiao, D. Li, C. Gai, Gasification performance of the hydrochar derived from co-hydrothermal carbonization of sewage sludge and sawdust, Energy. 173 (2019) 732-739, https://doi.org/10.1016/j energy.2019.02.103.

[78] J. Ren, F. Wang, Y. Zhai, Y. Zhu, C. Peng, T. Wang, C. Li, G. Zeng, Effect of sewage sludge hydrochar on soil properties and Cd immobilization in a contaminated soil, Chemosphere. 189 (2017) 627-633, https://doi.org/10.1016/j. chemosphere.2017.09.102.

[79] L. Leng, X. Yuan, H. Huang, J. Shao, H. Wang, X. Chen, G. Zeng, Bio-char derived from sewage sludge by liquefaction: Characterization and application for dye adsorption, Appl. Surf. Sci. 346 (2015) 223-231, https://doi.org/10.1016/j. apsusc. 2015.04.014.

[80] L. Li, Z.R. Xu, C. Zhang, J. Bao, X. Dai, Quantitative evaluation of heavy metals in solid residues from sub- and super-critical water gasification of sewage sludge, Bioresour. Technol. 121 (2012) 169-175, https://doi.org/10.1016/j. biortech.2012.06.084.

[81] Y. Yue, Y. Yao, Q. Lin, G. Li, X. Zhao, The change of heavy metals fractions during hydrochar decomposition in soils amended with different municipal sewage sludge hydrochars, J. Soils Sediments. 17 (3) (2017) 763-770, https://doi.org/ 10.1007/s11368-015-1312-2.

[82] Y.i. Liu, H. Qu, Design and optimization of a reactive crystallization process for high purity phosphorus recovery from sewage sludge ash, J. Environ. Chem. Eng. 4 (2) (2016) 2155-2162, https://doi.org/10.1016/j.jece:2016.03.042.

[83] L.M. Ottosen, G.M. Kirkelund, P.E. Jensen, Extracting phosphorous from incinerated sewage sludge ash rich in iron or aluminum, Chemosphere. 91 (7) (2013) 963-969, https://doi.org/10.1016/j.chemosphere.2013.01.101.

[84] M. Escala, T. Zumbühl, C.h. Koller, R. Junge, R. Krebs, Hydrothermal carbonization as an energy-efficient alternative to established drying technologies for sewage sludge: A feasibility study on a laboratory scale, Energy and Fuels. 27 (1) (2013) 454-460, https://doi.org/10.1021/ef3015266.

[85] T. Liu, Z. Liu, Q. Zheng, Q. Lang, Y. Xia, N. Peng, C. Gai, Effect of hydrothermal carbonization on migration and environmental risk of heavy metals in sewage 
sludge during pyrolysis, Bioresour. Technol. 247 (2018) 282-290, https://doi. org/10.1016/j.biortech.2017.09.090.

[86] X. Wang, Q. Chi, X. Liu, Y. Wang, Influence of pyrolysis temperature on characteristics and environmental risk of heavy metals in pyrolyzed biochar made from hydrothermally treated sewage sludge, Chemosphere. 216 (2019) 698-706, https://doi.org/10.1016/j.chemosphere.2018.10.189.

[87] Z. Xu, W. Zhu, J. Bao, J. Chen, The fate of heavy metal during subcritical and supercritical water gasification of sewage sludge, in: 2011 Int. Symp. Water Resour. Environ. Prot., IEEE, 2011: pp. 1260-1263. doi:10.1109/ ISWREP.2011.5893247.

[88] Y. Chen, H. Chen, R.W. Thring, H. Liu, J. Zhou, Y. Tao, J. Li, Immobilization of chromium contaminated soil by co-pyrolysis with rice straw, Water Air Soil Pollut. 231 (2020) 200, https://doi.org/10.1007/s11270-020-04581-3.

[89] S. Shao, H. Liu, X. Tai, F. Zheng, J. Li, Y. Li, Speciation and migration of heavy metals in sediment cores of urban wetland: bioavailability and risks, Environ. Sci. Pollut. Res. 27 (19) (2020) 23914-23925, https://doi.org/10.1007/s11356-020 08719-y.

[90] C. Vogel, M.C. Hoffmann, O. Krüger, V. Murzin, W. Caliebe, C. Adam, Chromium (VI) in phosphorus fertilizers determined with the diffusive gradients in thin-films (DGT) technique, Environ. Sci. Pollut. Res. 27 (19) (2020) 24320-24328, https:// doi.org/10.1007/s11356-020-08761-w.

[91] Y. Zhao, Q. Ren, Y. Na, Speciation transformation of arsenic during municipal sewage sludge incineration with cotton stalk as additive, Fuel. 202 (2017) 541-546, https://doi.org/10.1016/j.fuel.2017.04.074.

[92] Y. Zhao, Q. Ren, Y. Na, Effect of the addition of biomass on the fate and speciation of arsenic during sewage sludge combustion, Energy and Fuels. 32 (9) (2018) 9513-9518, https://doi.org/10.1021/acs.energyfuels.8b01871.

[93] S.M. Macedo, R.M. de Jesus, K.S. Garcia, V. Hatje, A.F. de S. Queiroz, S.L. C. Ferreira, Determination of total arsenic and arsenic (III) in phosphate fertilizers and phosphate rocks by HG-AAS after multivariate optimization based on BoxBehnken design, Talanta. 80 (2) (2009) 974-979, https://doi.org/10.1016/j. talanta.2009.08.025.

[94] J.J. González Medeiros, B. Pérez Cid, E. Fernández Gómez, Analytical phosphorus fractionation in sewage sludge and sediment samples, Anal. Bioanal. Chem. 381 2005 873-878. 10.1007/s00216-004-2989-z.

[95] V. Ruban, J.F. López-Sánchez, P. Pardo, G. Rauret, H. Muntau, P.h. Quevauviller, Harmonized protocol and certified reference material for the determination of extractable contents of phosphorus in freshwater sediments - A synthesis of recent works, Anal. Bioanal. Chem. 370 (2-3) (2001) 224-228, https://doi.org/ 10.1007/s002160100753.

[96] Y. Zhai, B. Xiang, H. Chen, B. Xu, L. Zhu, C. Li, G. Zeng, Recovery of phosphorus from sewage sludge in combination with the supercritical water process, Water Sci. Technol. 70 (2014) 1108-1114, https://doi.org/10.2166/wst.2014.344.

[97] S. Li, W. Zeng, Z. Jia, G. Wu, H. Xu, Y. Peng, Phosphorus species transformation and recovery without apatite in $\mathrm{FeCl} 3$-assisted sewage sludge hydrothermal treatment, Chem. Eng. J. 399 (2020) 125735, https://doi.org/10.1016/j. cej.2020.125735.

[98] Y. Xu, F. Yang, L. Zhang, X. Wang, Y. Sun, Q. Liu, G. Qian, Migration and transformation of phosphorus in municipal sludge by the hydrothermal treatmen and its directional adjustment, Waste Manag. 81 (2018) 196-201, https://doi. org /10.1016/j. wasman.2018.10.011.

[99] X. Zhang, L. Zhang, A. Li, Hydrothermal co-carbonization of sewage sludge and pinewood sawdust for nutrient-rich hydrochar production: Synergistic effects and products characterization, J. Environ. Manage. 201 (2017) 52-62, https://doi. org/10.1016/j.jenvman.2017.06.018.

[100] X. Zheng, Y. Ye, Z. Jiang, Z. Ying, S. Ji, W. Chen, B.o. Wang, B. Dou, Enhanced transformation of phosphorus (P) in sewage sludge to hydroxyapatite via hydrothermal carbonization and calcium-based additive, Sci. Total Environ. 738 (2020) 139786, https://doi.org/10.1016/j.scitotenv.2020.139786.

[101] T.-T. Qian, H. Jiang, Migration of phosphorus in sewage sludge during different thermal treatment processes, ACS Sustain. Chem. Eng. 2 (6) (2014) 1411-1419, https://doi.org/10.1021/sc400476j.

[102] S. Nanzer, A. Oberson, T. Huthwelker, U. Eggenberger, E. Frossard, The Molecular environment of phosphorus in sewage sludge ash: implications for bioavailability, J. Environ. Qual. 43 (3) (2014) 1050-1060, https://doi.org/10.2134/ jeq2013.05.0202.

[103] R. Huang, Y. Tang, Speciation dynamics of phosphorus during (hydro)thermal treatments of sewage sludge, Environ. Sci. Technol. 49 (24) (2015) 14466-14474 https://doi.org/10.1021/acs.est.5b0414010.1021/acs.est.5b04140.s001.

[104] R. Huang, Y. Tang, Evolution of phosphorus complexation and mineralogy during (hydro)thermal treatments of activated and anaerobically digested sludge: Insights from sequential extraction and P K-edge XANES, Water Res. 100 (2016) 439-447, https://doi.org/10.1016/j.watres.2016.05.029.

[105] Q. Wang, C. Zhang, P. Liu, H. Jung, B. Wan, D. Patel, S.G. Pavlostathis, Y. Tang, Effect of interstage hydrothermal treatment on anaerobic digestion of sewage sludge: Speciation evolution of phosphorus, iron, and sulfur, ACS Sustain. Chem. Eng. 8 (44) (2020) 16515-16525, https://doi.org/10.1021/ acssuschemeng.0c05544.

[106] S. Petzet, B. Peplinski, S.Y. Bodkhe, P. Cornel, Recovery of phosphorus and aluminium from sewage sludge ash by a new wet chemical elution process (SESAL-Phos-recovery process), Water Sci. Technol. 64 (2011) 693-699, https:// doi.org/10.2166/wst.2011.682.

[107] J.-S. Li, Z. Chen, Q.-M. Wang, L.e. Fang, Q. Xue, C.R. Cheeseman, S. Donatello, L. Liu, C.S. Poon, Change in re-use value of incinerated sewage sludge ash due to chemical extraction of phosphorus, Waste Manag. 74 (2018) 404-412, https:// doi.org/10.1016/j.wasman.2018.01.007.
[108] S. Donatello, A. Freeman-Pask, M. Tyrer, C.R. Cheeseman, Effect of milling and acid washing on the pozzolanic activity of incinerator sewage sludge ash, Cem. Concr. Compos. 32 (1) (2010) 54-61, https://doi.org/10.1016/j cemconcomp.2009.09.002.

[109] C. Adam, B. Peplinski, M. Michaelis, G. Kley, F.-G. Simon, Thermochemical treatment of sewage sludge ashes for phosphorus recovery, Waste Manag. 29 (3) (2009) 1122-1128, https://doi.org/10.1016/j.wasman.2008.09.011.

[110] N.Y. Acelas, D.P. López, D.W.F. Wim Brilman, S.R.A. Kersten, A.M.J. Kootstra, Supercritical water gasification of sewage sludge: Gas production and phosphorus recovery, Bioresour. Technol. 174 (2014) 167-175, https://doi.org/10.1016/j. biortech.2014.10.003.

[111] Y. Yu, X.i. Yang, Z. Lei, R. Yu, K. Shimizu, N. Chen, C. Feng, Z. Zhang, Effects of three macroelement cations on $\mathrm{P}$ mobility and speciation in sewage sludge derived hydrochar by using hydrothermal treatment, Bioresour. Technol. Reports. 7 (2019) 100231, https://doi.org/10.1016/j.biteb.2019.100231.

[112] X. Zheng, X. Zheng, Z. Jiang, Z. Ying, Z. Ying, Y. Ye, W. Chen, B. Wang, B. Wang, B. Dou, B. Dou, Migration and Transformation of Phosphorus during Hydrothermal Carbonization of Sewage Sludge: Focusing on the Role of $\mathrm{pH}$ and Calcium Additive and the Transformation Mechanism, ACS Sustain. Chem. Eng. 8 (2020) 7806-7814, https://doi.org/10.1021/acssuschemeng.0c00031.

[113] T.T. Wang, Y. Zhai, Y. Zhu, C. Peng, T.T. Wang, B. Xu, C. Li, G. Zeng, Feedwater $\mathrm{pH}$ affects phosphorus transformation during hydrothermal carbonization of sewage sludge, Bioresour. Technol. 245 (2017) 182-187, https://doi.org/ 10.1016/j.biortech.2017.08.114.

[114] N. Semerci, S. Ahadi, S. Coşgun, Comparison of dried sludge and sludge ash for phosphorus recovery with acidic and alkaline leaching, Water Environ. J. 35 (1) (2021) 359-370, https://doi.org/10.1111/wej.v35.110.1111/wej.12633.

[115] U.S. Department of Agriculture, Superphosphate: Its History, Chemistry, and Manufacture, U.S. Government Printing Office, Washington, D.C., 1964.

[116] L.e. Fang, J.-S. Li, S. Donatello, C.R. Cheeseman, Q. Wang, C.S. Poon, D.C W. Tsang, Recovery of phosphorus from incinerated sewage sludge ash by combined two-step extraction and selective precipitation, Chem. Eng. J. 348 (2018) 74-83, https://doi.org/10.1016/j.cej.2018.04.201.

[117] B.K. Biswas, K. Inoue, H. Harada, K. Ohto, H. Kawakita, Leaching of phosphorus from incinerated sewage sludge ash by means of acid extraction followed by adsorption on orange waste gel, J. Environ. Sci. 21 (12) (2009) 1753-1760, https://doi.org/10.1016/S1001-0742(08)62484-5.

[118] S.L. Goss, K.A. Lemons, J.E. Kerstetter, R.H. Bogner, Determination of calcium salt solubility with changes in $\mathrm{pH}$ and $\mathrm{P} \mathrm{CO} 2$, simulating varying gastrointestinal environments, J. Pharm. Pharmacol. 59 (2007) 1485-1492, https://doi.org/ 10.1211/jpp.59.11.0004.

[119] J. Shukla, V.P. Mohandas, A. Kumar, Effect of $\mathrm{pH}$ on the solubility of CaSO4.2H2O in aqueous $\mathrm{NaCl}$ solutions and physicochemical solution properties at $35^{\circ} \mathrm{C}$, J. Chem. Eng. Data. 53 (12) (2008) 2797-2800, https://doi.org/ 10.1021/je800465f.

[120] T. Iwama, C.-M. Du, S. Koizumi, X.u. Gao, S. Ueda, S.-y. Kitamura, Extraction of phosphorus and recovery of phosphate from steelmaking slag by selective leaching, ISIJ Int. 60 (2) (2020) 400-407, https://doi.org/10.2355/ isijinternational.ISIJINT-2019-298.

[121] C.M. Du, X. Gao, S. Ueda, S.Y. Kitamura, Effects of cooling rate and acid on extracting soluble phosphorus from slag with high $\mathrm{P} 2 \mathrm{O} 5$ content by selective leaching, ISIJ Int. 57 (2017) 487-496, https://doi.org/10.2355/isijinternational. ISIJINT-2016-510.

[122] K. Gorazda, Z. Kowalski, Z. Wzorek, From sewage sludge ash to calcium phosphate fertilizers, Polish J. Chem. Technol. 14 (2012) 54-58, https://doi.org/ 10.2478/v10026-012-0084-3.

[123] H. Xu, H. Zhang, L. Shao, P. He, Fraction distributions of phosphorus in sewage sludge and sludge ash, Waste and Biomass Valorization. 3 (3) (2012) 355-361, https://doi.org/10.1007/s12649-011-9103-5.

[124] M. Atienza-Martínez, G. Gea, J. Arauzo, S.R.R.A. Kersten, A.M.J. Kootstra, Phosphorus recovery from sewage sludge char ash, Biomass and Bioenergy. 65 (2014) 42-50, https://doi.org/10.1016/j.biombioe.2014.03.058.

[125] Q. Wang, J.-S. Li, P. Tang, L.e. Fang, C.S. Poon, Sustainable reclamation of phosphorus from incinerated sewage sludge ash as value-added struvite by chemical extraction, purification and crystallization, J. Clean. Prod. 181 (2018) 717-725, https://doi.org/10.1016/j.jclepro.2018.01.254.

[126] K. Gorazda, B. Tarko, Z. Wzorek, A.K. Nowak, J. Kulczycka, A. Henclik, Characteristic of wet method of phosphorus recovery from polish sewage sludge ash with nitric acid, Open Chem. 14 (2016) 37-45, https://doi.org/10.1515/ chem-2016-0006.

[127] G.C. Becker, D. Wüst, H. Köhler, A. Lautenbach, A. Kruse, Novel approach of phosphate-reclamation as struvite from sewage sludge by utilising hydrothermal carbonization, J. Environ. Manage. 238 (2019) 119-125, https://doi.org/ 10.1016/j.jenvman.2019.02.121.

[128] G. Hu, J. Li, X. Zhang, Y. Li, Investigation of waste biomass co-pyrolysis with petroleum sludge using a response surface methodology, J. Environ. Manage. 192 (2017) 234-242, https://doi.org/10.1016/j.jenvman.2017.01.069.

[129] C. Meyer, V. Preyl, H. Steinmetz, W. Maier, R.-E. Mohn, H. Schönberger, T. Pierson, The Stuttgart Process (Germany), in: Phosphorus Polluter Resour. Futur. - Remov. Recover. from Wastewater, International Water Association, 2018: pp. 375-390. doi:10.2166/9781780408361_375.

[130] T. Falayi, Alkaline recovery of phosphorous from sewage sludge and stabilisation of sewage sludge residue, Waste Manag. 84 (2019) 166-172, https://doi.org/ 10.1016/j.wasman.2018.11.041.

[131] J. Cao, Y. Wu, J. Zhao, S. Jin, M. Aleem, Q. Zhang, F. Fang, Z. Xue, J. Luo, Phosphorus recovery as vivianite from waste activated sludge via optimizing iron 
source and $\mathrm{pH}$ value during anaerobic fermentation, Bioresour. Technol. 293 (2019) 122088, https://doi.org/10.1016/j.biortech.2019.122088.

[132] K. ichi Sonoda, Alkaline leaching of phosphate from sewage sludge ash, in: Phosphorus Recover. Recycl., Springer Singapore, 2018: pp. 143-148. doi: 10.1007/978-981-10-8031-98.

[133] C. Barca, M. Martino, P. Hennebert, N. Roche, Kinetics and capacity of phosphorus extraction from solid residues obtained from wet air oxidation of sewage sludge, Waste Manag. 89 (2019) 275-283, https://doi.org/10.1016/j. wasman.2019.04.024.

[134] H. Nakagawa, J. Ohta, Phosphorus recovery from sewage sludge ash: A case study in Gifu, Japan, in: Phosphorus Recover. Recycl. Springer Singapore (2018) 149-155, https://doi.org/10.1007/978-981-10-8031-9 9.

[135] M.M.T. Zin, D. Tiwari, D.J. Kim, Maximizing ammonium and phosphate recovery from food wastewater and incinerated sewage sludge ash by optimal Mg dose with RSM, J. Ind. Eng. Chem. 86 (2020) 136-143, https://doi.org/10.1016/j. jiec.2020.02.020.

[136] S. Daneshgar, A. Buttafava, A. Callegari, A.G. Capodaglio, Economic and energetic assessment of different phosphorus recovery options from aerobic sludge, J. Clean. Prod. 223 (2019) 729-738, https://doi.org/10.1016/j jclepro.2019.03.195.

[137] M. Abel-Denee, T. Abbott, C. Eskicioglu, Using mass struvite precipitation to remove recalcitrant nutrients and micropollutants from anaerobic digestion dewatering centrate, Water Res. 132 (2018) 292-300, https://doi.org/10.1016/j. watres.2018.01.004.

[138] C. Lc, Next generation calcium phosphate-based biomaterials, Dent. Mater. J. 28 (2009) $1-10$.

[139] J. Liu, X. Cheng, X. Qi, N. Li, J. Tian, B. Qiu, K. Xu, D. Qu, Recovery of phosphate from aqueous solutions via vivianite crystallization: Thermodynamics and influence of pH, Chem. Eng. J. 349 (2018) 37-46, https://doi.org/10.1016/j. cej.2018.05.064.

[140] Doan Pham Minh, Ngoc Dung Tran, Ange Nzihou, Patrick Sharrock, Hydroxyapatite gel for the improved removal of $\mathrm{Pb} 2+$ ions from aqueous solution, Chem. Eng. J. 232 (2013) 128-138, https://doi.org/10.1016/j. cej.2013.07.086.

[141] Alibaba Group, Manufacturers, Exporters \& Importers from the worlds largest online marketplace, Suppliers, 2020 https://www.alibaba.com/ (accessed November 20, 2020).

[142] National Center for Biotechnology Information, PubChem, (2020). https:// pubchem.ncbi.nlm.nih.gov/ (accessed November 20, 2020).

[143] S. Daneshgar, P.A. Vanrolleghem, C. Vaneeckhaute, A. Buttafava, A. G. Capodaglio, Optimization of P compounds recovery from aerobic sludge by chemical modeling and response surface methodology combination, Sci. Total Environ. 668 (2019) 668-677, https://doi.org/10.1016/j.scitotenv.2019.03.055.

[144] F. Abbona, H.E.Lundager Madsen, R. Boistelle, The initial phases of calcium and magnesium phosphates precipitated from solutions of high to medium concentrations, J. Cryst. Growth. 74 (3) (1986) 581-590, https://doi.org/ 10.1016/0022-0248(86)90205-8.

[145] S. Daneshgar, A. Buttafava, D. Capsoni, A. Callegari, A.G. Capodaglio, Impact of $\mathrm{pH}$ and ionic molar ratios on phosphorous forms precipitation and recovery from different wastewater sludges, Resources. 7 (2018) 71, https://doi.org/10.3390/ resources7040071.

[146] M.T. Munir, B. Li, I. Boiarkina, S. Baroutian, W. Yu, B.R. Young, Phosphate recovery from hydrothermally treated sewage sludge using struvite precipitation,
Bioresour. Technol. 239 (2017) 171-179, https://doi.org/10.1016/j. biortech.2017.04.129.

[147] European Sustainable Phosphorus Platform, ESPP - DPP - NNP phosphorus recovery technology catalogue, 2020. https://www.phosphorusplatform.eu/ activities/p-recovery-technology-inventory.

[148] Yonghui Song, Hermann H. Hahn, Erhard Hoffmann, Effects of solution conditions on the precipitation of phosphate for recovery: A thermodynamic evaluation, Chemosphere. 48 (10) (2002) 1029-1034, https://doi.org/10.1016/ S0045-6535(02)00183-2.

[149] P. Wilfert, A.I. Dugulan, K. Goubitz, L. Korving, G.J. Witkamp, M.C.M. Van Loosdrecht, Vivianite as the main phosphate mineral in digested sewage sludge and its role for phosphate recovery, Water Res. 144 (2018) 312-321, https://doi, org/10.1016/j.watres.2018.07.020.

[150] F. Yaya, J.P. Nguetnkam, R. Tchameni, S.D. Basga, J. Penaye, Assessment of the Fertilizing effect of Vivianite on the Growth and yield of the Bean " " phaseolus vulgaris "' on Oxisoils from Ngaoundere (Central North), Int. Res. J. Earth Sci. 3 (2015) 18-26. www.isca.me (accessed November 24, 2020).

[151] I. Díaz, V. Barrón, M.C. del Campillo, J. Torrent, Testing the ability of vivianite to prevent iron deficiency in pot-grown grapevine, Sci. Hortic. (Amsterdam) 123 (4) (2010) 464-468, https://doi.org/10.1016/j.scienta.2009.11.006.

[152] Ricky Priambodo, Yu-Jen Shih, Yao-Hui Huang, Phosphorus recovery as ferrous phosphate (vivianite) from wastewater produced in manufacture of thin film transistor-liquid crystal displays (TFT-LCD) by a fluidized bed crystallizer (FBC), RSC Adv. 7 (65) (2017) 40819-40828, https://doi.org/10.1039/C7RA06308C.

[153] C. Zhang, D. Hu, R. Yang, Z. Liu, Effect of sodium alginate on phosphorus recovery by vivianite precipitation, J. Environ. Sci. (China) 93 (2020) 164-169, https://doi.org/10.1016/j.jes.2020.04.007.

[154] A. Amann, O. Zoboli, J. Krampe, H. Rechberger, M. Zessner, L. Egle, Environmental impacts of phosphorus recovery from municipal wastewater, Resour. Conserv. Recycl. 130 (2018) 127-139, https://doi.org/10.1016/j. resconrec.2017.11.002

[155] N. Rastetter, K.O. Rothhaupt, A. Gerhardt, Ecotoxicological assessment of phosphate recyclates from sewage sludges, Water, Air, Soil Pollut. 228 (2017) 171, https://doi.org/10.1007/s11270-017-3331-7.

[156] M. Gong, Y. Wang, Y. Fan, W. Zhu, H. Zhang, Y. Su, Polycyclic aromatic hydrocarbon formation during the gasification of sewage sludge in sub- and supercritical water: Effect of reaction parameters and reaction pathways, Waste Manag. 72 (2018) 287-295, https://doi.org/10.1016/j.wasman.2017.11.024.

[157] K. Wiedner, C. Rumpel, C. Steiner, A. Pozzi, R. Maas, B. Glaser, Chemical evaluation of chars produced by thermochemical conversion (gasification, pyrolysis and hydrothermal carbonization) of agro-industrial biomass on a commercial scale, Biomass and Bioenergy. 59 (2013) 264-278, https://doi.org/ 10.1016/j.biombioe.2013.08.026.

[158] Heiner Brookman, Fabian Gievers, Volker Zelinski, Jan Ohlert, Achim Loewen, Influence of hydrothermal carbonization on composition, formation and elimination of biphenyls, dioxins and furans in sewage sludge, Energies. 11 (6) (2018) 1582, https://doi.org/10.3390/en11061582.

[159] A.V. Mitroshkov, L. Zhong, L.M.P. Thomas. Analysis of Perfluorinated, Pharmaceutical, Personal Care Compounds and Heavy Metals in Waste Water Sludge using GC-MS/MS and Multicollector ICP-MS, U.S. Department of Energy, Oak, Ridge, TN (United States), 2019, https://doi.org/10.2172/1494304. 